\title{
Patterns of reduced cortical thickness and striatum pathological morphology in cocaine addiction.
}

Eduardo A Garza-Villarreal ${ }^{*}, 1,2$, Ruth Alcalá-Lozano, Thania Balducci ${ }^{1,3}$, Diego Ángeles-Valdéz4, M. Mallar Chakravarty ${ }^{5,6,7}$, Gabriel A. Devenyi ${ }^{5,6}$, Jorge J Gonzalez-Olvera'.

1 Subdirección de Investigaciones Clínicas, Instituto Nacional de Psiquiatría "Ramón de la Fuente Muñiz", Mexico City, Mexico

2 Center of Functionally Integrative Neuroscience (CFIN) and MINDLab, Department of Clinical Medicine, Aarhus University, Aarhus, Denmark

${ }^{3}$ Graduate School of Medical Sciences, Universidad Nacional Autónoma de México, Mexico City, Mexico.

${ }^{4}$ Faculty of Psychology, Universidad Nacional Autónoma de México, Mexico City, Mexico.

${ }^{5}$ Cerebral Imaging Centre, Douglas Mental Health University Institute, Montreal, QC, Canada.

${ }^{6}$ Department of Psychiatry, McGill University, Montreal, Canada

${ }^{7}$ Department of Biomedical Engineering, McGill University, Montreal, Canada

\section{Corresponding author:}

Eduardo A. Garza-Villarreal, M.D., Ph.D.

Subdireccion de Investigaciones Clinicas, Instituto Nacional de Psiquiatria "Ramón de la Fuente Muñiz", Calzada Mexico-Xochimilco 101, Col. San Lorenzo Huipulco, Delegación Tlalpan, C.P. 14370 , Mexico City, Mexico

Phone: +52 (55) 41605354

Email: egarza@imp.edu.mx 


\begin{abstract}
Substance addiction is regarded as an important public health problem, perpetuated by fronto-striatal circuit pathology. A usual finding in neuroimaging human and murine studies is cortical thinning and lower volume when compared to healthy controls. In this study we wished to replicate cortical thinning findings and find if striatum morphology may explain the cortical pathology. For this we analyzed T1w neuroimaging data from an ongoing addiction Mexican dataset. This dataset includes cocaine addicts diagnosed by expert psychiatrists and healthy controls. For the analysis we used voxel-based morphometry, cortical thickness and volumetric analysis of the basal ganglia, and we correlated striatum volume with cortical thickness to find pathological patterns. Our group contrast showed cortical thinning and striatum volume differences in cocaine addicts correlated to their years of substance use, craving and age. Our correlation between striatum-cortex morphology showed higher significant correlations in healthy controls, not observed in cocaine addicts. The correlation between striatum volume and cortical thickness in healthy controls involved similar areas as those shown with less cortical thickness in cocaine addicts. We suggest that striatum morphological changes in addiction may explain the pattern of cortical thinning observed across several substances addiction studies.
\end{abstract}




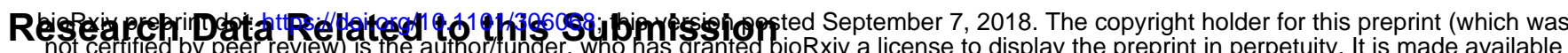
under aCC-BY-NC 4.0 International license.

Data set

https://zenodo.org/record/1409808\#.W5E3oCOZPIF

Patterns of reduced cortical thickness and striatum pathological morphology in cocaine addiction

This dataset includes all the data and scripts needed to reproduce the analysis and results on the manuscript

"Patterns of reduced cortical thickness and striatum pathological morphology in cocaine addiction" (link). The brain data is not raw, as T1w were not defaced. We will do so in the near future for version 2.0. Instead we include only the "output/thickness" files used in the final analysis. For the use of raw T1w images, please contact the main author EAGV. 


\section{Introduction}

Substance addiction is a generalized problem in the world accompanied by important psychiatric comorbidities and exacerbated by poor treatment outcomes ${ }^{1}$. In Mexico, cocaine is the second most used illegal substance of abuse among the population of users, and it inflicts social, family, economical and health problems (https://www.gob.mx/salud\%7Cconadic/acciones-yprogramas/encuesta-nacional-de-consumo-de-drogas-alcohol-y-tabaco-

encodat-2016-2017-136758). Volkow et al. ${ }^{2}$ have proposed a hypothesis that substance addiction is a pathological cycle of behavior, and that chronic drug use directly and indirectly affects brain areas such as the striatum and thalamus and their cortical connectivity. Such neurobiological changes perpetuate and potentially reinforce the addiction cycle. The consistent reinforcement of this cycle leads to addictive behaviors commonly observed in individuals suffering from addiction ${ }^{3}$. As a result, a brain circuit involving the striatum, thalamus and prefrontal areas is commonly studied to better understand how brain function and structure is altered in those suffering from addictions ${ }^{4,5}$. Recent studies in humans and murine models have supported pathological fronto-striatal connectivity as the main driver of the addiction cycle and substance seeking ${ }^{6,7}$.

Human neuroimaging studies using voxel-based morphometry (VBM) and cortical thickness (CT) have typically demonstrated variable brain differences, usually including decreased volume or CT in prefrontal, temporal, occipital and subcortical areas in the brains of addicts ${ }^{8-13}$, although there have been increase volume findings in striatum ${ }^{14}$. The decrease in these measures is usually correlated with behavioral (i.e. substance craving) and cognitive measures 15,16. A meta-analysis in cocaine and methamphetamine addicts found lower volume on bilateral insula, left thalamus, left middle frontal gyrus (ImFG), right anterior cingulate ( $\mathrm{ACC}$ ) and right inferior frontal gyrus (rIFG) ${ }^{17}$. Parvaz et al ${ }^{18}$ recently demonstrated that the volume of the inferior frontal gyrus (IFG) and the medial prefrontal cortex (mPFC) increase following treatment for cocaine addiction. These studies suggest brain morphology is highly affected in addiction, and that treatment success can partly revert this damage. These areas found with reduced volume or CT in addiction such as the insula, IFG, mPFC, ACC, have also been found connected structurally and functionally to the different nuclei of the striatum ${ }^{19}$. If striatum is a region highly affected in addiction and it is intimately connected with these cortical areas, which in turn seem to be commonly found affected in addiction, pathological morphological changes in striatum may help explain the reduction of cortical thickness and volume in such widespread areas of the cortex.

In this study, we wish to find neuroanatomical differences between cocaine addicts and matched healthy controls, to better understand the toxic effect of drug use and the effect of craving. We also wanted to study the relation between striatum structure and cortical thickness. For this, we used novel computational anatomy algorithms to perform volumetric analysis, cortical thickness extraction and subcortical segmentation of striatum and thalamus.

\section{Materials and Methods}




\section{Participants}

We recruited 160 participants as part of a principal multidisciplinary addiction study at the Instituto Nacional de Psiquiatría "Ramón de la Fuente Muñiz" in Mexico City, Mexico. Of those, 49 participants did not fulfill the inclusion criteria. We diagnosed cocaine dependence using the MINI International Neuropsychiatric Interview Spanish version ${ }^{20}$, which was administered by trained psychiatrists. For inclusion, cocaine consumption had to be active or with abstinence less than 60 days prior to the scan, with frequency of use of at least three days per week and no more than 60 continued days of abstinence during the last 12 months. There could be polysubstance use, however cocaine had to be the drug of impact. Additional exclusion criteria for both groups were: somatic diseases, neurological disorders, severe suicidal risk, history of head trauma with loss of consciousness, pregnancy, obesity, severe psychiatric disorders and non-compliance with magnetic resonance imaging safety standards. A final sample of 64 cocaine addicts (AD) ( 7 female) and 47 healthy controls $(\mathrm{HC})$ (8 female) were included in our study. Healthy controls were matched as closely as possible by age $( \pm 2 y)$, sex and handedness. Education was matched as closely as possible, though it has significantly higher in $\mathrm{HC}$, therefore education was added as a covariate in the statistical analysis. Table 1 describe the demographic and addiction related information. The study was approved by the local ethics committee and performed at the Instituto Nacional de Psiquiatría "Ramón de la Fuente Muñiz" in Mexico City, Mexico. The study was carried out according to the Declaration of Helsinki. All participants were invited through posters placed in several centers for addiction treatment and through the Institute's addiction clinic for outpatients. Healthy controls were recruited from the Institute (i.e. administrative workers, their family, etc) and using Internet social outlets. Participants provided verbal and written informed consent. The participants underwent clinical and cognitive tests besides the MRI as part of the main ongoing addiction database. Participants were asked to abstain from drug use for at least 24 hours prior to the study and were urinetested for the presence of the drugs and a breath determination of alcohol in the blood before the MRI scan. The clinical, cognitive and MRI sessions were performed either the same day as minimum, or 4 days apart as maximum. It is important to point out none of our participants were homeless or in extreme poverty.

Table 1. Demographic and substance addiction variables between groups.

\begin{tabular}{llll} 
Variable & HC & AD & p \\
\hline & $(\mathrm{N}=47)$ & $(\mathrm{N}=64)$ & \\
Age & $30.7 \pm 7.6$ & $31.0 \pm 7.2$ & 0.846 \\
Sex & & & 0.519 \\
- F & & & \\
- M & $8(17.0 \%)$ & $7(10.9 \%)$ & \\
& $39(83.0 \%)$ & $57(89.1 \%)$ &
\end{tabular}


Education

Handedness

$$
3.7 \pm 1.5
$$

$2.9 \pm 1.2$

0.003

- A

$-\mathrm{L}$

$-R$

BIS Total

$\begin{array}{rrrr} & 40.6 \pm 11.5 & 60.9 \pm 15.2 & <.001 \\ \text { - } B I S \text { ICog } 11.9 \pm 3.7 & 17.2 \pm 5.4 & <.001 \\ \text { - } \text { BIS IMo } 12.7 \pm 6.0 & 18.2 \pm 7.5 & <.001 \\ \text { - } \text { BIS INoPI } 15.9 \pm 5.6 & 25.5 \pm 7.6 & <.001\end{array}$

Cigarettes per day

$1.2 \pm 1.4$

$3.7 \pm 4.4$

0.006

(tobacco)

Initial Age

$$
3(6.4 \%) \quad 4(6.2 \%)
$$

$4(8.5 \%) \quad 5(7.8 \%)$

$40(85.1 \%) \quad 55(85.9 \%)$

Years of Consumption

Craving (CCQ General)

$-$

$21.67 \pm 6.15 \quad-$

$\mathrm{HC}=$ Healthy Control; $\mathrm{AD}=$ Cocaine Addict; $\mathrm{F}=$ female; $\mathrm{M}=$ male; $\mathrm{A}=$ Ambidexterous; $\mathrm{L}=\mathrm{Left}$ handed, R = Right handed, BIS = Barrat Impulsivity Scale; ICog = Cognitive; IMo = Motor; INoPI $=$ Non-Planning; $C C Q=$ Cocaine Craving Quotient.

\section{Clinical measures}

Craving in the last month and at the interview was measured using the cocaine craving questionnaire (CCQ) ${ }^{21}$. Self-reported impulsivity was evaluated with the Barratt Impulsiveness Scale (BIS-11), which has three subscales: non-planning impulsiveness, which involves a lack of forethought; cognitive impulsivity, which involves making quick decisions; and motor impulsivity, which involves acting without thinking 22 .

\section{MRI Acquisition}

T1-weighted brain data were acquired using a Philips Ingenia 3T Magnetic Resonance Imaging (MRI) system (Philips Healthcare, Best, Netherlands \& Boston, MA, USA) with a 32-channel dS Head coil. T1-weighted images were acquired using a 3D FFE SENSE sequence, TR/TE $=7 / 3.5 \mathrm{~ms}$, FOV $=240$, matrix $=240 \times 240 \mathrm{~mm}, 180$ slices, gap $=0$, plane $=$ Sagittal, voxel $=1 \times 1 \times 1$ $\mathrm{mm}$ (5 participants were acquired with a voxel size $=.75 \times .75 \times 1 \mathrm{~mm}$ ), scan time $=3.19 \mathrm{~min}$. As part of the principal addiction database, resting state $\mathrm{fMRI}$, High Angular Resolution Diffusion Imaging (HARD), and Diffusion Kurtosis Imaging (DKI) sequences were also acquired and are not part of this study. The order of the sequences was: rsfMRI, T1w, HARDI, DKI, and was maintained across participants. Total scan time was $\sim 50$ minutes.

\section{Image preprocessing and processing}


T1-weighted images were converted from DICOM format to MINC for preprocessing. T1 images were preprocessed using an in-house preprocessing pipeline with the software Bpipe (https://github.com/CobraLab/minc-bpipelibrary $)^{23}$, which makes use of the MINC Tool-Kit (http://www.bic.mni.mcgill.ca/ServicesSoftware/ServicesSoftwareMincToolKit) and ANTs ${ }^{24}$. Briefly, we performed N4 bias field correction ${ }^{25}$, linear registration to $\mathrm{MNI}$-space using ANTs, we cropped the region around the neck in order improve registration quality, followed by transformation back to native space, and created whole-brain masks.

We estimated volume-based (VBM) and surfaced-based variables (cortical thickness [CT] and surface area [SA]) using the CIVET processing pipeline (version 1.1.12; Montreal Neurological Institute). First, the T1w images were linearly aligned to the ICBM 152 average template using a 9-parameter transformation ( 3 translations, rotations, and scales) ${ }^{26}$ and preprocessed to minimize the effects of intensity non-uniformity ${ }^{27}$. The images were then classified into three main tissues: gray matter (GM), white matter (WM) and cerebrospinal fluid (CSF) ${ }^{28}$. GM was used for VBM. The hemispheres were modeled as GM and WM surfaces using a deformable model strategy that generates 4 separate surfaces defined by 40962 vertices each ${ }^{29}$. CT was derived between homologous vertices on GM and WM derived using the t-link metric and blurred with a $20 \mathrm{~mm}$ surface-based diffusion kernel, while SA was estimated by averaging across the adjoining faces at each vertex ${ }^{30}$. Nativespace thicknesses were used in all analyses reported ${ }^{31,32}$. Homology across the population was achieved using a non-linear surface-based normalization that utilizes a mid-surface (between pial and WM surfaces) ${ }^{33}$. This normalization uses a depth-potential function ${ }^{34}$ that fits each subject to $a$ minimally biased surface-based template ${ }^{35}$.

For the subcortical analysis, the native space preprocessed files were input into the MAGeT-Brain morphological analysis pipeline (http://cobralab.ca/software/MAGeTbrain.html) ${ }^{36}$. MAGeT-Brain is modified multi-atlas segmentation technique designed to take advantage of hard-todefine atlases and uses a minimal number of atlases for input into the segmentation process. The used a basal ganglia atlas ${ }^{37}$ obtained by manual segmentation of one brain. We obtained segmentation and volume measures for striatum, thalamus and globus pallidus.

\section{Statistical analysis}

Voxel based morphometry (VBM) gray matter and vertex-wise analyses were performed with the RMINC package (https://wiki.phenogenomics.ca/display/MICePub/RMINC) in $\mathrm{R}$ statistics and RStudio ${ }^{38}$. Public packages used for the analysis were: tidyverse, psych, pastecs, moonBook and plotrix. The general linear model included "CT" as the dependent variable, "group" as the between subjects variable, and "age", "sex" and "education" as covariates. All analyses were corrected for multiple comparisons using the false discovery rate (FDR) at $10 \%{ }^{39}$. From the resulting significant peaks we extracted MNI coordinates and labels based on the AAL 
atlas ${ }^{40}$, except for VBM in which we used Harvard-Oxford Cortical Atlas ${ }^{41-44}$. As post-hoc, we calculated the correlation coefficient between years of consumption and craving, and all the significant peaks CT. Using that matrix, we statistically analyzed only correlations that exceeded a chosen threshold of $r$ $= \pm 0.2$ (low-medium effect size) using the t-distribution with an alpha of 0.05 . We then used the FDR to adjust the p-value for multiple comparisons of the correlations. As a side note, VBM was only calculated because it is a more widely used measure of brain morphology. Because we were more interested in cortical thickness, we did not further analyze this measure. However, tools such as BrainMap (http://brainmap.org) would be able to use this data for future meta-analyses.

\section{Basal ganglia analysis}

We studied basal ganglia volumes using a general linear model that included subcortical volume as the dependent variable, group as the between-subjects variable, and age, sex and education as covariates. Our previous study in cocaine addiction showed mainly group $x$ age interactions in striatum volume ${ }^{45}$, hence we performed that interaction model as well. We then calculated the correlation coefficient between years of consumption and craving, and all basal ganglia including their striatum and thalamus segmentation. Using that matrix, we statistically analyzed only correlations that exceeded a chosen threshold of $r$ $= \pm 0.2$ (low-medium effect size) using the $\mathrm{t}$-distribution with an alpha of 0.05. Because basal ganglia volume is relative to whole-brain volume, we then performed partial correlations controlling for whole-brain volume.

\section{Striatum-cortex correlation analysis}

The covariation between striatum subnuclei that were correlated significantly with years of consumption and craving (left nucleus accumbens and right precommissural precuneus), and whole-brain cortical thickness was studied using a similar approach to the "Mapping anatomical correlations across cerebral cortex (MACACC)" analysis method "46. The MACACC method is performed by selecting a seed region of interest (ROI) and correlating the CT of this ROI with the CT of all brain vertices. This approach is similar to functional connectivity analysis 47,48 . The resulting statistic gives an indication of the degree to which CT throughout the brain covaries with the ROI across subjects and can be used to estimated the structural and functional connectivity between different areas. As our ROI, we chose to instead use the volume of the significant nuclei in the partial correlation analysis: left nucleus accumbens and right pre-commissural putamen volume (basal ganglia analysis). We also chose whole left and right striatum volume to corroborate our results. This method has been used successfully ${ }^{49}$. We then correlated the volume of each ROI against the brain vertices for all participants, and then each group separately. All maps were FDR corrected at $5 \%$ due to the high distribution of significant peaks.

\section{Results}


We found significantly lower volume (Supplementary Figure $1 \&$ Table 1) and cortical thickness in cocaine addicts in mainly prefrontal areas (Figure 1 and Supplementary Table 2). VBM showed 2 small clusters of increased volume that were not found in the CT analysis. Surface area was not significant.

\section{Insert Figure 1}

The post-hoc analysis showed that years of cocaine consumption and craving were significantly correlated with several CT peaks (Supplementary Figs. 2 and 3, Supplementary Tables 2 and 3). The subcortical analysis showed a significant lower volume in left thalamus of the AD group $(F(1,104)=4.723, p=$ 0.03) (Supplementary Fig. 4) than the HC group. There was no difference in striatum and globus pallidus volume. There was, however, a significant group $x$ age interaction in left and right striatum volume (Figure 2) at alpha 0.1 (left: $F$ $(1,103)=2.83, p=0.1$; right: $F(1,103)=3.26, p=0.07)$, which was similar to our previous findings ${ }^{45}$.

\section{Insert Figure 2}

The bivariate correlation analysis of years of consumption and craving with basal ganglia volumes, showed no significant results. The partial correlation analysis controlling for whole-brain volume showed significant negative correlation between: 1) years of consumption and left nucleus accumbens ( $r=-$ $0.23, t=-2.46, p=0.02)$, and 2$)$ craving and right pre-commissural putamen $(r$ $=-0.27, \mathrm{t}=-2.89, \mathrm{p}=0.005)$.

The striatum-cortex correlation analysis results using the ROls: 1) left nucleus accumbens (INAcc) and 2) right pre-commisual putamen (rPrePut), are shown in Figure 3. The result of left and right whole striatum volume are in the Supplementary Figure 5. The resulting significant covariance maps show INAcc and rPrePut volumes are related to similar areas that showed lower cortical thickness in $A D$ in the $C T$ group comparison (Figure 1). A subset analysis showed that the correlation between INAcc and cortex in AD is nonexistent compared to $\mathrm{HC}$. The subset analysis of correlation between rPrePut and cortex showed higher significant correlations in $\mathrm{HC}$ than the $\mathrm{AD}$ group. For this last analysis, significant brain areas of correlation shared between groups are shown in Table 2. As for whole striatum volume, we also found higher correlation in $\mathrm{HC}$ compared to AD. All peak tables are shown in Supplementary Tables 5 to 15. In general, striatum volume in AD showed low correlation to cortical thickness compared to healthy controls.

Insert Figure 3

Table 2. Significant peaks in similar brain areas between groups in the correlation analysis between right precommissural putamen and cortical thickness. 


\begin{tabular}{lllllllllll} 
& \multicolumn{1}{l}{ HC } & \multicolumn{1}{c}{ AD } & & & & \\
\cline { 2 - 10 } Brain Area & vertex & $\mathbf{x}$ & $\mathbf{y}$ & $\mathbf{z}$ & $\mathbf{t}$ & vertex & $\mathbf{x}$ & $\mathbf{y}$ & $\mathbf{z}$ & $\mathbf{t}$ \\
\hline $\begin{array}{l}\text { Left Superior temporal } \\
\text { gyrus }\end{array}$ & 10435 & -41 & -18 & -1 & 3.28 & 13033 & -44 & 3 & -15 & 4.86 \\
$\begin{array}{l}\text { Left Middle temporal } \\
\text { gyrus }\end{array}$ & 35910 & -61 & -54 & -7 & 3.75 & 13282 & -49 & 13 & -29 & 4.36 \\
$\begin{array}{l}\text { Left Inferior occipital } \\
\text { gyrus }\end{array}$ & 576 & -59 & -60 & -9 & 3.92 & 33470 & -36 & -88 & -17 & 4.18 \\
Left Precentral gyrus & 26769 & -24 & -3 & 54 & 2.88 & 20887 & -53 & -5 & 30 & 3.94 \\
\hline
\end{tabular}

$\mathrm{HC}=$ healthy controls, $\mathrm{AD}=$ cocaine addicts, vertex $=$ Surface vertex CIVET 1.1.12, $\mathrm{t}=$ tvalue .

\section{Discussion}

In our study, Mexican cocaine addicts showed lower gray matter volume and cortical thickness in several brain areas, with the most extensive difference on prefrontal cortex. Cortical thickness and striatal subnuclei volume were significantly correlated to years of cocaine use and craving. The covariation between striatal whole and subnuclei volumes, and cortical thickness suggests close neuroanatomical pathology of fronto-striatal areas in cocaine addicts.

Using VBM and CT analysis we found significantly lower values in cocaine addicts (AD) than healthy controls (HC). In VBM we found increased volume in two areas that were not found in the CT analysis, probably due to the differences between methods. These findings of cortical thinning are not surprising as they have been shown in other studies of different type of addiction ${ }^{9,10,50}$, corroborating cortical pathology from chronic cocaine use. The cortical thinning was observed in areas of all cortical lobes, slightly lateralized to the left hemisphere. Although we did not find group differences between volumes in striatum, we found an age $x$ group interaction that suggests a pathological development related to addiction and or chronic use. The striatal subnuclei nucleus accumbens and precommissural putamen were correlated with years of cocaine use and craving. Striatum volume differences, when compared to healthy controls, can be present or absent, higher or lower, in different studies ${ }^{14,51}$, which suggests either a complex pathology when measured with these methods or differences in volumetric and segmentation methods. Nevertheless, animal and humans studies corroborate the involvement of the striatum in addiction and affectation of its morphology ${ }^{52-54}$.

A landmark study by Chen et al ${ }^{6}$ using optogenetics showed that seeking for cocaine in addicted mice could be effectively stopped by stimulating the prelimbic cortex (mPFC or DLPFC in human), while inhibiting this region induced the opposite effect, increased cocaine seeking. In humans, a similar effect has been observed by stimulating the DLPFC using rTMS where cocaine addicts report reduced craving and cocaine use ${ }^{55}$. The fronto-striatal circuit is involved in response inhibition, which is found to be greatly affected in cocaine 
addiction in animal models and in human studies, and this circuit includes the striatum, thalamus, globus pallidus, primary motor cortex, ACC, dmPFC and the VIPFC ${ }^{5}$. However, the structural connectivity between the striatum and cerebral cortex seems to be more extended, involving also areas such as the SFG, IFG, temporal pole and occipital cortex ${ }^{19}$. Substance addiction is a complex condition and at the moment the main hypothesis for the etiology of the addictive cycle is the fronto-striatal circuit pathology ${ }^{2,56}$. Although the causal direction of the pathology (fronto-striatal or striato-frontal) has not been demonstrated yet, the involvement of dopamine receptors in striatum suggests a mainly striatal pathology ${ }^{57}$.

The covariation between INAcc/rPrePut volume and CT of all participants (striatum-cortex covariation) seems to follow a similar pattern to the structural connectivity of the striatum. Interestingly, not only our group contrast map of lower CT in cocaine addicts shows similarities with the striatum-cortex covariation, but also this covariation was only observed in healthy controls and it almost disappeared in cocaine addicts. This could be an indication of the underlying pathological changes in striatum or cortex (or both), secondary to cocaine addiction or chronic use. This shared morphological finding have been shown in young adult smokers with lower CT in frontal cortical areas and higher volume of the caudate ${ }^{58}$. In a study with several types of substances, another study showed lower volume in frontal areas as well as the caudate nucleus, among others ${ }^{59}$. As for the involvement of striatum pathology and cortex morphology in human addiction, a recent study showed that striatal D1-type receptor (dopamine) levels are correlated with mean global cortical thickness in methamphetamine users but not in controls, specifically in temporal and occipital lobes ${ }^{60}$. The authors suggest this abnormality may be a cortical adaptation to chronic substance use with involvement of the D1-type. The evidence highly suggests that the observed morphological findings in cortex may be due to either striatum pathology, or cortical pathology may drive the striatum changes that engrain this pathology. Confirming a causal relationship would help explain the shared cortical findings across types of substance addiction and would corroborate the hypothesis about dopamine related frontostriatal dysfunction as one of the main causes of human substance addiction.

Our study has several limitations. Correlational studies cannot prove causality as they can only suggest relationships that can be studied further in real experimental designs. However, it is obvious that experimental designs in substance addiction are unethical in humans; hence we rely on animal studies and correlational designs in humans to provide knowledge. Our significant threshold for the multiple comparisons FDR in the CT analysis was $10 \%(q=$ 0.1 ), which may be considered more liberal than usual and caution should be taken when interpreting our findings. However, this approach was preferred to allow for a more exploratory study and we have successfully used it in our previous studies. Our dataset is unique and ongoing, and because addiction and polysubstance use is complex, we wanted to avoid false negatives. The corroboration of our results in relation to other studies seem to support our use of a more relaxed threshold in this particular sample. Our sample is mainly males due to the prevalence of cocaine addiction in this sex, which is a problem in all cocaine addiction studies. 
Our results show a possible relation between striatum volume and cortical thinning in cocaine addiction, which further confirms fronto-striatal pathology. Specifically, we believe our results suggest that the pattern of cortical thinning found in most addiction studies may be explained by striatal pathology. Future studies should aim at corroborating the cortical connectivity between striatum and cortex in substance addiction using advance non-invasive diffusion methods.

\section{Acknowledgements}

We would like to thank Rocio Estrada Ordoñez and Isabel Lizarindari Espinosa Luna at the Unidad de Atención Toxicologica Xochimilco for all their help and effort. Finally, we thank the study participants for their cooperation and patience. This project was funded by CONACYT-FOSISS-S0008 project No. 0260971, No. 0201493 and CONACYT-Cátedras project No. 2358948. For the use of the Harvard-Oxford Atlas, we are very grateful for the training data for FIRST, particularly to David Kennedy at the CMA, and also to: Christian Haselgrove, Centre for Morphometric Analysis, Harvard; Bruce Fischl, Martinos Center for Biomedical Imaging, MGH; Janis Breeze and Jean Frazier, Child and Adolescent Neuropsychiatric Research Program, Cambridge Health Alliance; Larry Seidman and Jill Goldstein, Department of Psychiatry of Harvard Medical School; Barry Kosofsky, Weill Cornell Medical Center.

\section{Conflicts of Interest}

The authors declare no conflicts of interest.

\section{References}

1 Alvarez Y, Pérez-Mañá C, Torrens M, Farré M. Antipsychotic drugs in cocaine dependence: a systematic review and meta-analysis. $J$ Subst Abuse Treat 2013; 45: 1-10.

2 Volkow ND, Koob GF, McLellan AT. Neurobiologic Advances from the Brain Disease Model of Addiction. N Engl J Med 2016; 374: 363-371.

3 Volkow ND, Morales M. The Brain on Drugs: From Reward to Addiction. Cell 2015; 162: 712-725.

4 Goldstein RZ, Volkow ND. Drug addiction and its underlying neurobiological basis: neuroimaging evidence for the involvement of the frontal cortex. Am J Psychiatry 2002; 159: 1642-1652. 
5 Morein-Zamir S, Robbins TW. Fronto-striatal circuits in response-inhibition: Relevance to addiction. Brain Res 2015; 1628: 117-129.

6 Cheng X, Li T, Zhou H, Zhang Q, Tan J, Gao W et al. Cortical electrical stimulation with varied low frequencies promotes functional recovery and brain remodeling in a rat model of ischemia. Brain Res Bull 2012; 89: 124132.

7 Smith WC, Rosenberg MH, Claar LD, Chang V, Shah SN, Walwyn WM et al. Frontostriatal Circuit Dynamics Correlate with Cocaine Cue-Evoked Behavioral Arousal during Early Abstinence. eNeuro 2016; 3.

doi:10.1523/ENEURO.0105-16.2016.

8 Makris N, Gasic GP, Kennedy DN, Hodge SM, Kaiser JR, Lee MJ et al. Cortical Thickness Abnormalities in Cocaine Addiction-A Reflection of Both Drug Use and a Pre-existing Disposition to Drug Abuse? Neuron 2008; 60: 174-188.

9 Kühn S, Schubert F, Gallinat J. Reduced thickness of medial orbitofrontal cortex in smokers. Biological Psychiatry 2010; 68: 1061-1065.

10 Durazzo TC, Tosun D, Buckley S, Gazdzinski S, Mon A, Fryer SL et al. Cortical Thickness, Surface Area, and Volume of the Brain Reward System in Alcohol Dependence: Relationships to Relapse and Extended Abstinence. Alcoholism: Clinical and Experimental Research 2011; 35: 1187-1200.

11 Lopez-Larson MP, Bogorodzki P, Rogowska J, McGlade E, King JB, Terry $\mathrm{J}$ et al. Behavioural Brain Research. Behavioural Brain Research 2011; 220: 164-172.

12 Ersche KD, Barnes A, Jones PS, Morein-Zamir S, Robbins TW, Bullmore ET. Abnormal structure of frontostriatal brain systems is associated with aspects of impulsivity and compulsivity in cocaine dependence. Brain 2011; 134: 2013-2024.

13 Pehlivanova M, Wolf DH, Sotiras A, Kaczkurkin A, Moore TM, Ciric R et al. Diminished Cortical Thickness is Associated with Impulsive Choice in Adolescence. Journal of Neuroscience 2018; : 2200-17.

14 Ersche KD, Jones PS, Williams GB, Turton AJ, Robbins TW, Bullmore ET. Abnormal brain structure implicated in stimulant drug addiction. Science 2012; 335: 601-604.

15 Ersche KD. Neurobiological correlates of the familial risk for stimulant drug dependence. Neuropsychopharmacology 2013; 38: 238-239.

16 Levar N, Francis AN, Smith MJ, Ho WC, Gilman JM. Verbal Memory Performance and Reduced Cortical Thickness of Brain Regions Along the Uncinate Fasciculus in Young Adult Cannabis Users. Cannabis and Cannabinoid Research 2018; 3: 56-65. 
17 Ersche KD, Williams GB, Robbins TW, Bullmore ET. Meta-analysis of structural brain abnormalities associated with stimulant drug dependence and neuroimaging of addiction vulnerability and resilience. Current Opinion in Neurobiology 2013; 23: 615-624.

18 Parvaz MA, Moeller SJ, d'Oleire Uquillas F, Pflumm A, Maloney T, AliaKlein $\mathrm{N}$ et al. Prefrontal gray matter volume recovery in treatment-seeking cocaine-addicted individuals: a longitudinal study. Addict Biol 2017; 22: 1391-1401.

19 Jarbo K, Verstynen TD. Converging structural and functional connectivity of orbitofrontal, dorsolateral prefrontal, and posterior parietal cortex in the human striatum. Journal of Neuroscience 2015; 35: 3865-3878.

20 Ferrando L, Soto M, Bobes J, Soto O, Franco L, Gibert J. Mini International Neuropsychiatric Interview (Spanish version 5.0). Madrid: Institute IAP 2000.

21 Sussner BD, Smelson DA, Rodrigues S, Kline A, Losonczy M, Ziedonis D. The validity and reliability of a brief measure of cocaine craving. Drug Alcohol Depend 2006; 83: 233-237.

22 Oquendo MA, Baca-García E, Graver R, Morales M, Montalvan V, Mann J. Spanish adaptation of the Barratt impulsiveness scale (BIS-11). European Journal of Psychiatry 2001; 15: 147-155.

23 Sadedin SP, Pope B, Oshlack A. Bpipe: a tool for running and managing bioinformatics pipelines. Bioinformatics 2012; 28: 1525-1526.

24 Avants BB, Tustison N, Song G. Advanced Normalization Tools (ANTS) Release 1.5. University of Pennsylvania, 2011.

25 Tustison NJ, Avants BB, Cook PA, Zheng Y, Egan A, Yushkevich PA et al. N4ITK: improved N3 bias correction. IEEE Trans Med Imaging 2010; 29: 1310-1320.

26 Collins DL, Collins DL, Neelin P, Neelin P, Peters TM, Peters TM et al. Automatic 3D intersubject registration of MR volumetric data in standardized Talairach space. J Comput Assist Tomogr 1994; 18: 192205.

27 Sled JG, Zijdenbos AP, Evans AC. A nonparametric method for automatic correction of intensity nonuniformity in MRI data. IEEE Trans Med Imaging 1998; 17: 87-97.

28 Zijdenbos AP, Forghani R, Evans AC. Automatic 'pipeline' analysis of 3-D MRI data for clinical trials: application to multiple sclerosis. IEEE Trans Med Imaging 2002; 21: 1280-1291.

29 Kim JS, Singh V, Lee JK, Lerch J, Ad-Dab'bagh Y, MacDonald D et al. Automated 3-D extraction and evaluation of the inner and outer cortical surfaces using a Laplacian map and partial volume effect classification. 
Human Brain Mapping Journal 2005; 27: 210-221.

30 Lerch JP, Evans AC. Cortical thickness analysis examined through power analysis and a population simulation. Neurolmage 2005; 24: 163-173.

31 YYasser A-D, Singh V, Robbins S, Lerch J, Lyttelton O, Fombonne E et al. Native-space cortical thickness measurement and the absence of correlation to cerebral volume. 11th Annual Organization for Human Brain Mapping Meeting 2005; : 1-1.

32 Sowell ER, Sowell ER, Peterson BS, Peterson BS, Kan E, Kan E et al. Sex Differences in Cortical Thickness Mapped in 176 Healthy Individuals between 7 and 87 Years of Age. Cerebral Cortex 2007; 17: 1550-1560.

33 Robbins S, Evans AC, Collins DL, Whitesides S. Tuning and comparing spatial normalization methods. Med Image Anal 2004; 8: 311-323.

34 Boucher M, Whitesides S, Evans A. Depth potential function for folding pattern representation, registration and analysis. Med Image Anal 2009; 13: 203-214.

35 Lyttelton O, Boucher M, Robbins S, Evans A. An unbiased iterative group registration template for cortical surface analysis. Human Brain Mapping Journal 2007; 34: 1535-1544.

36 Chakravarty MM, Steadman P, van Eede MC, Calcott RD, Gu V, Shaw P et al. Performing label-fusion-based segmentation using multiple automatically generated templates. Hum Brain Mapp 2013; 34: 2635-2654.

37 Chakravarty MM, Bertrand G, Hodge CP, Sadikot AF, Collins DL. The creation of a brain atlas for image guided neurosurgery using serial histological data. Human Brain Mapping Journal 2006; 30: 359-376.

38 Team R. RStudio: Integrated Development for R. RStudio, Inc., Boston, MA URL http://www.rstudio.com/. 2015.

39 Genovese CR, Lazar NA, Nichols T. Thresholding of statistical maps in functional neuroimaging using the false discovery rate. Human Brain Mapping Journal 2002; 15: 870-878.

40 Schmahmann JD, Doyon J, McDonald D, Holmes C, Lavoie K, Hurwitz AS et al. Three-dimensional MRI atlas of the human cerebellum in proportional stereotaxic space. Human Brain Mapping Journal 1999; 10: 233-260.

41 Frazier JA, Chiu S, Breeze JL, Makris N, Lange N, Kennedy DN et al. Structural brain magnetic resonance imaging of limbic and thalamic volumes in pediatric bipolar disorder. Am J Psychiatry 2005; 162: 12561265.

42 Makris N, Goldstein JM, Kennedy D, Hodge SM, Caviness VS, Faraone SV et al. Decreased volume of left and total anterior insular lobule in schizophrenia. Schizophrenia Research 2006; 83: 155-171. 
43 Desikan RS, Ségonne F, Fischl B, Quinn BT, Dickerson BC, Blacker D et al. An automated labeling system for subdividing the human cerebral cortex on MRI scans into gyral based regions of interest. Neurolmage 2006; 31 : 968-980.

44 Goldstein JM, Seidman LJ, Makris N, Ahern T, O'Brien LM, Caviness VS et al. Hypothalamic abnormalities in schizophrenia: sex effects and genetic vulnerability. Biological Psychiatry 2007; 61: 935-945.

45 Garza-Villarreal EA, Chakravarty MM, Hansen B, Eskildsen SF, Devenyi GA, Castillo-Padilla D et al. The effect of crack cocaine addiction and age on the microstructure and morphology of the human striatum and thalamus using shape analysis and fast diffusion kurtosis imaging. Transl Psychiatry 2017; 7: e1122.

46 Lerch JP, Worsley K, Shaw WP, Greenstein DK, Lenroot RK, Giedd J et al. Mapping anatomical correlations across cerebral cortex (MACACC) using cortical thickness from MRI. Neurolmage 2006; 31: 993-1003.

47 Friston KJ. Testing for anatomically specified regional effects. Hum Brain Mapp 1997; 5: 133-136.

48 Worsley KJ, Chen J-I, Lerch J, Evans AC. Comparing functional connectivity via thresholding correlations and singular value decomposition. Philos Trans R Soc Lond, B, Biol Sci 2005; 360: 913-920.

49 Ameis SH, Ducharme S, Albaugh MD, Hudziak JJ, Botteron KN, Lepage C et al. Cortical Thickness, Cortico-Amygdalar Networks, and Externalizing Behaviors in Healthy Children. Biological Psychiatry 2014; 75: 65-72.

50 Kaag AM, Crunelle CL, van Wingen G, Homberg J, van den Brink W, Reneman L. Relationship between trait impulsivity and cortical volume, thickness and surface area in male cocaine users and non-drug using controls. Drug Alcohol Depend 2014; 144: 210-217.

51 Barrós-Loscertales A, Garavan H, Bustamante JC, Ventura-Campos N, Llopis JJ, Belloch V et al. Reduced striatal volume in cocaine-dependent patients. Human Brain Mapping Journal 2011; 56: 1021-1026.

52 Wheeler AL, Lerch JP, Chakravarty MM, Friedel M, Sled JG, Fletcher PJ et al. Adolescent Cocaine Exposure Causes Enduring Macroscale Changes in Mouse Brain Structure. Journal of Neuroscience 2013; 33: 1797-1803.

53 Janes AC, Park MTM, Farmer S, Chakravarty MM. Striatal morphology is associated with tobacco cigarette craving. Neuropsychopharmacology 2015; 40: 406-411.

54 Li S, Yang Y, Hoffmann E, Tyndale RF, Stein EA. CYP2A6 Genetic Variation Alters Striatal-Cingulate Circuits, Network Hubs, and Executive Processing in Smokers. Biological Psychiatry 2017; 81: 554-563.

55 Terraneo A, Leggio L, Saladini M, Ermani M, Bonci A, Gallimberti L. 
Transcranial magnetic stimulation of dorsolateral prefrontal cortex reduces cocaine use: A pilot study. Eur Neuropsychopharmacol 2016; 26: 37-44.

56 Jaworska N, Cox SM, Casey KF, Boileau I, Cherkasova M, Larcher K et al. Is there a relation between novelty seeking, striatal dopamine release and frontal cortical thickness? PLOS ONE 2017; 12: e0174219.

57 Volkow ND, Baler RD. Addiction science: Uncovering neurobiological complexity. Neuropharmacology 2014; 76: 235-249.

$58 \mathrm{Li} \mathrm{Y,} \mathrm{Yuan} \mathrm{K,} \mathrm{Cai} \mathrm{C,} \mathrm{Feng} \mathrm{D,} \mathrm{Yin} \mathrm{J,} \mathrm{Bi} \mathrm{Y} \mathrm{et} \mathrm{al.} \mathrm{Drug} \mathrm{and} \mathrm{Alcohol}$ Dependence. Drug Alcohol Depend 2015; 151: 211-219.

59 Moreno-López L, Catena A, Fernández-Serrano MJ, Delgado-Rico E, Stamatakis EA, Pérez-García $\mathrm{M}$ et al. Trait impulsivity and prefrontal gray matter reductions in cocaine dependent individuals. Drug Alcohol Depend 2012; 125: 208-214.

60 Okita K, Morales AM, Dean AC, Johnson MC, Lu V, Farahi J et al. Striatal dopamine D1-type receptor availability: no differencefrom control but association with cortical thickness inmethamphetamine users. Molecular psychiatry 2017; : 1-8.

\section{Figure Legends}

Figure 1. Cortical thickness group difference.

Left column views $=1$ ) medial, left hemisphere, 2) lateral, left hemisphere, 3) superior, 4) frontal. Right column views = 1) media, right hemisphere, 2) lateral, right hemisphere, 3) inferior, 4) occipital.

Figure 2. Scatter plot of group $x$ age interaction in striatum volume.

$\mathrm{HC}=$ Healthy controls; $\mathrm{AD}=$ cocaine addicts. The corrected volumes are the residuals of the linear model without group and age.

Figure 3. Correlation of left nucleus accumbens and right pre-commissural putamen with cortical thickness.

Red-yellow colours show significant vertices. $\mathrm{HC}=$ Healthy controls, $\mathrm{AD}=$ cocaine addicts, INAcc = left nucleus accumbens, $r$ PrePut $=$ right precommissural putamen. In INAcc, for the AD group, there were were no significant peaks below FDR 5\%. 
Left Striatum

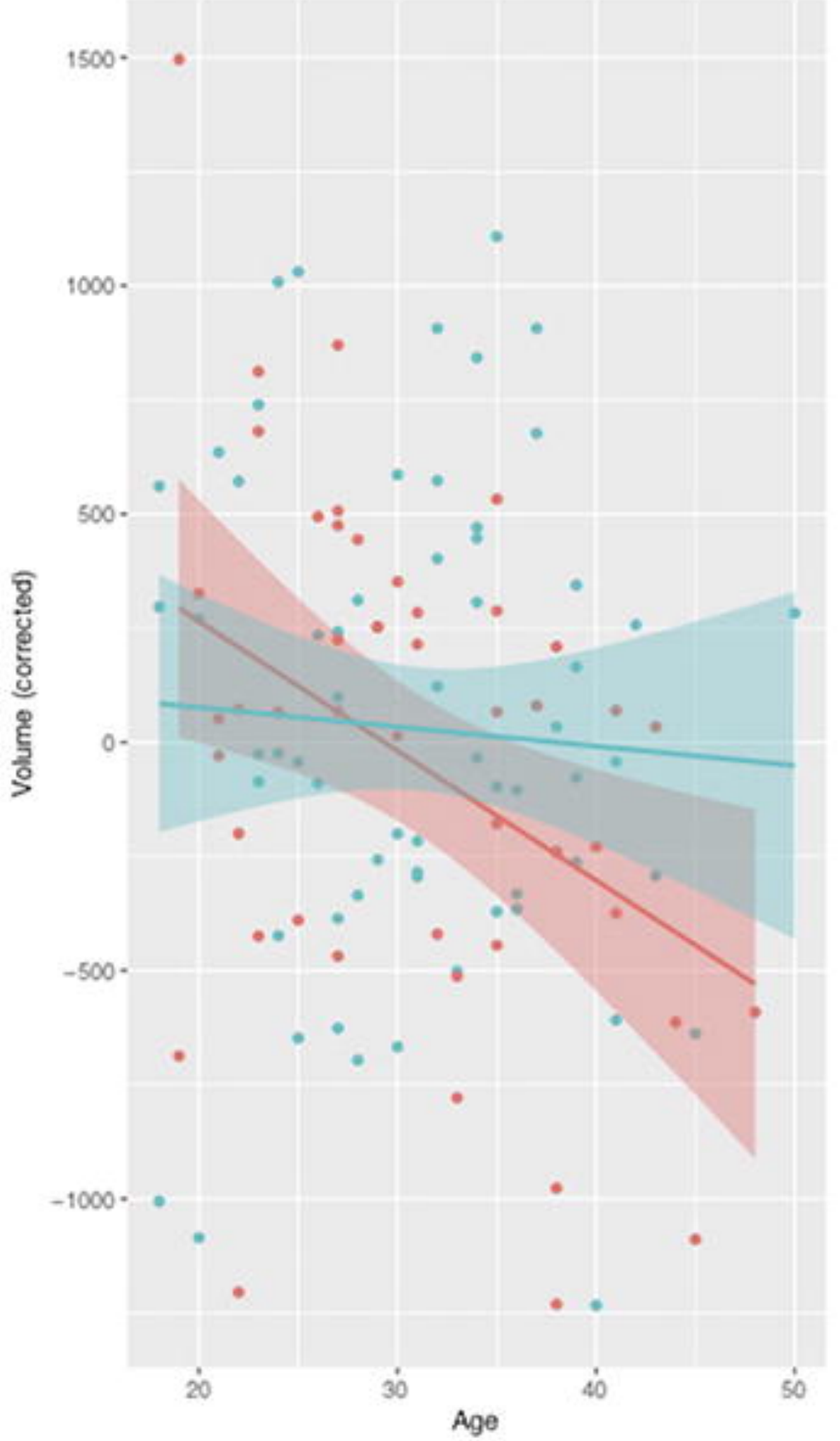

Right Striatum

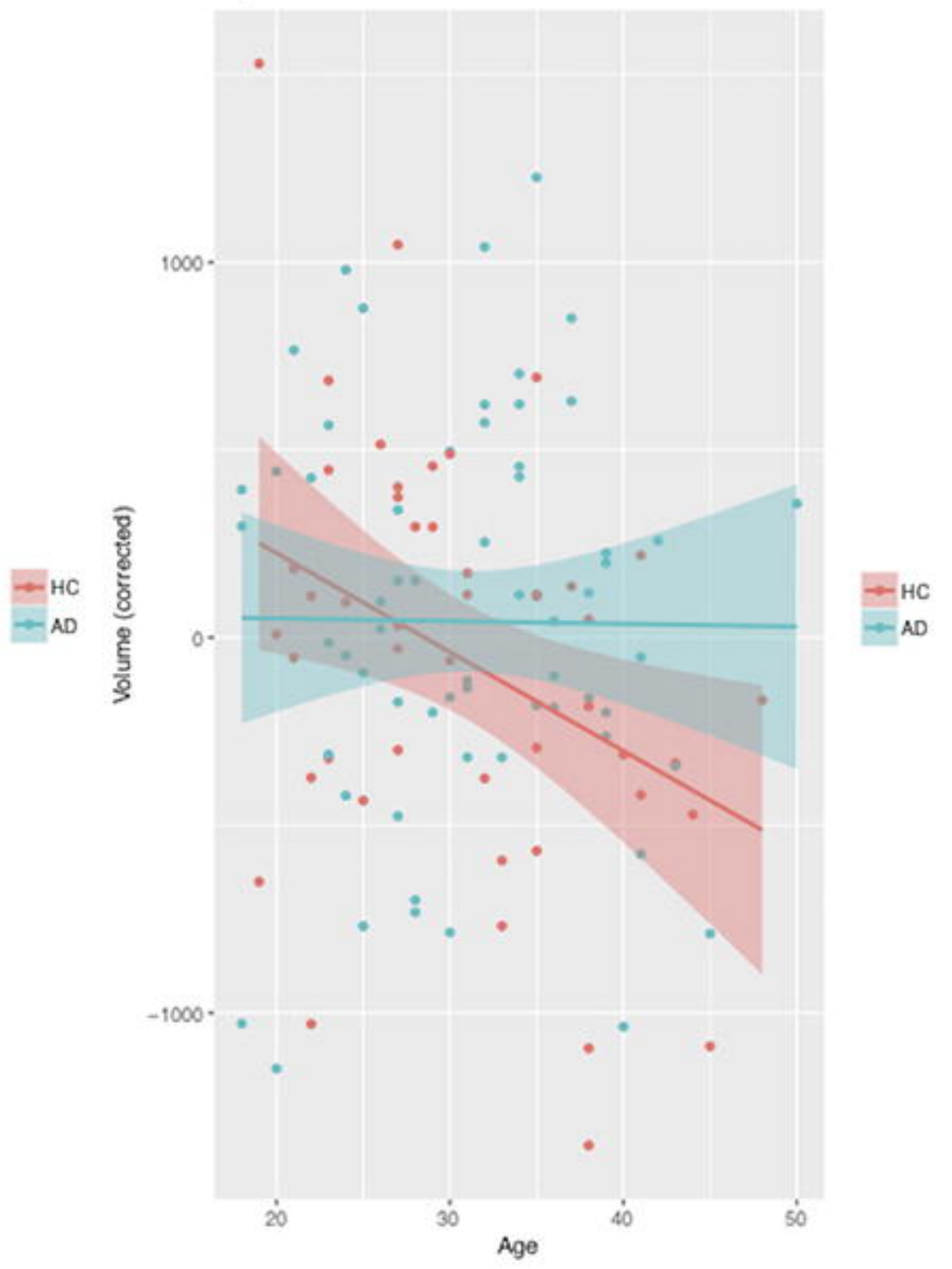




\section{INAcC}

12 N

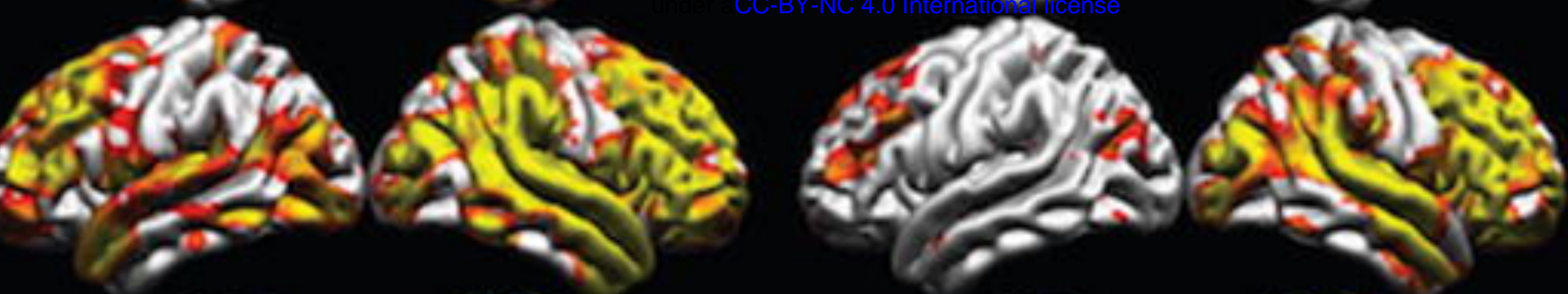
2. th

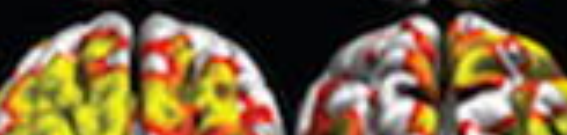
60

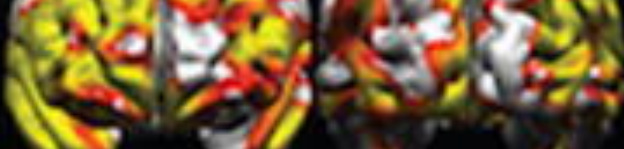
mon

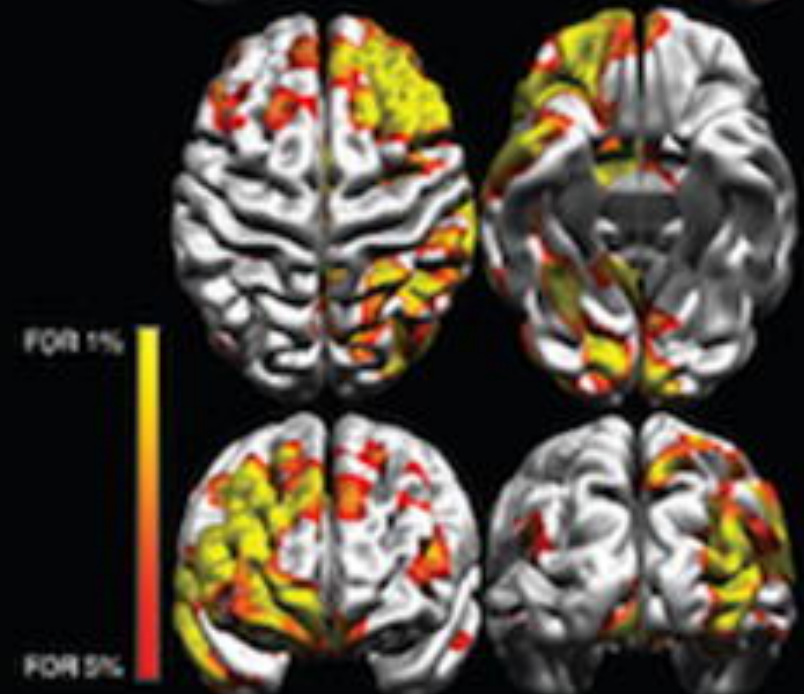
(n)

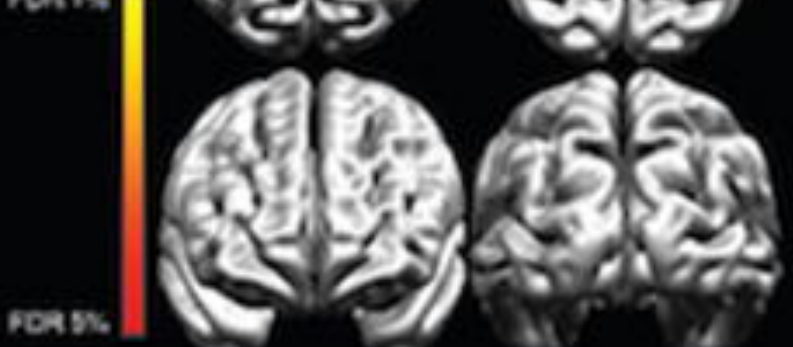

\section{rPrePut}

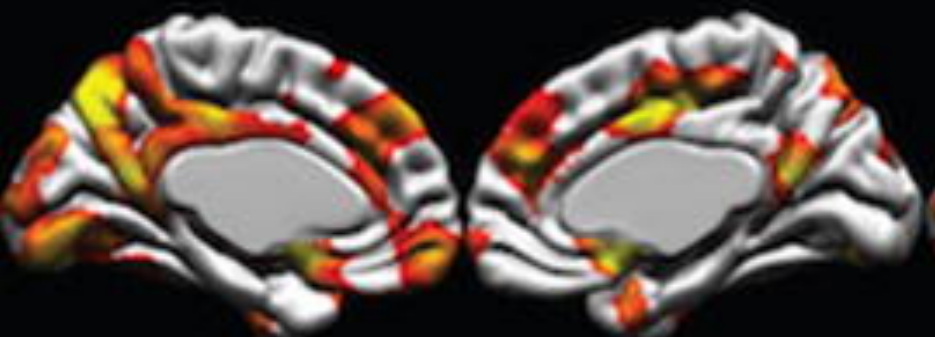

8 觔。

(I)

s.

-

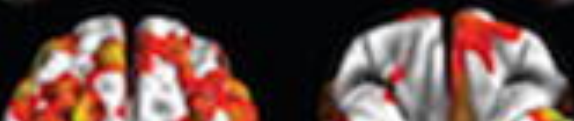

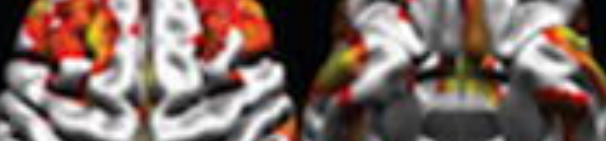
and

estor

(a) (6) 30 . 35

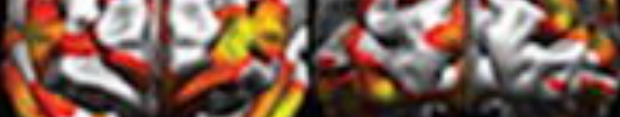

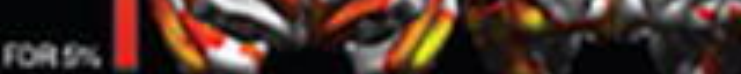

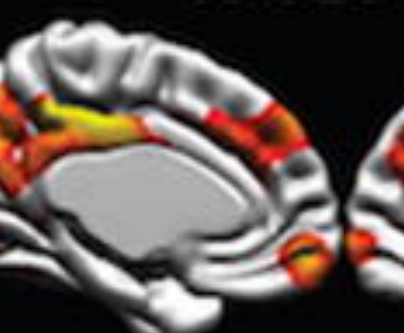

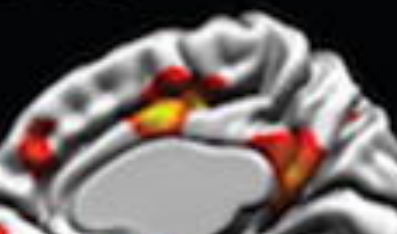

$\rightarrow 2$
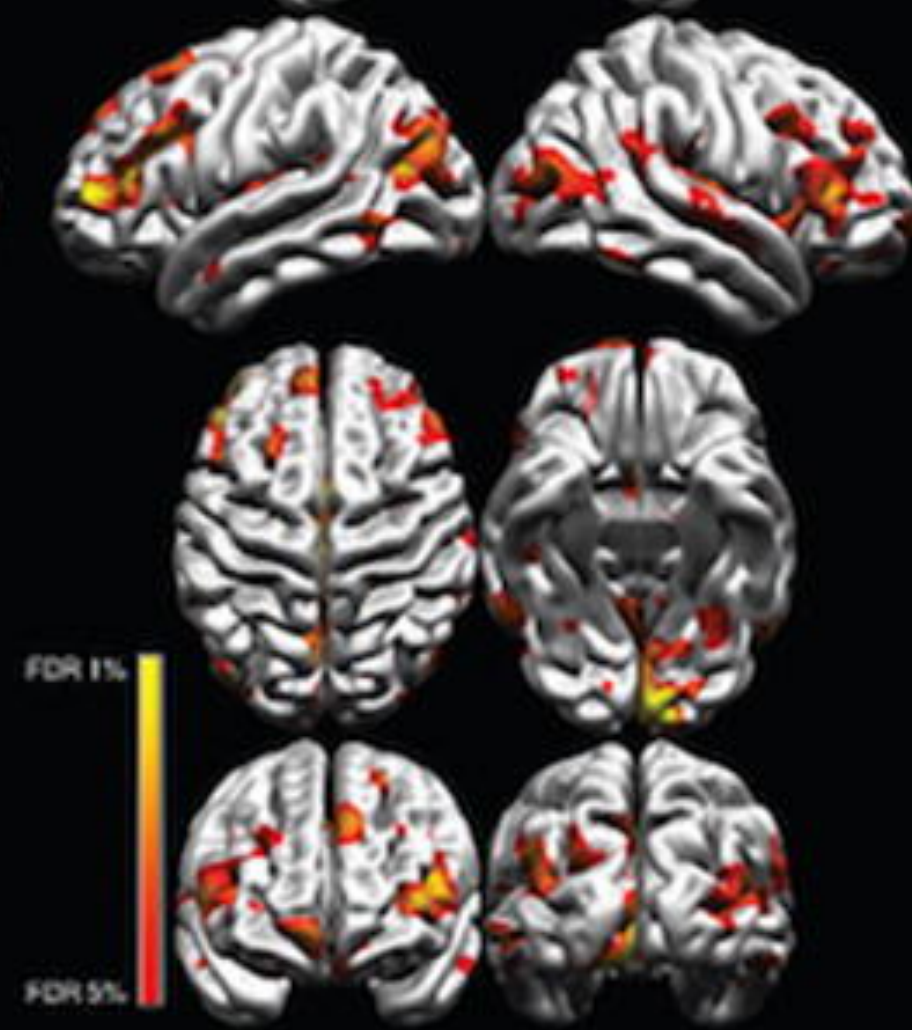

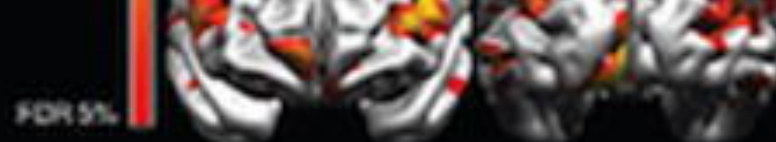
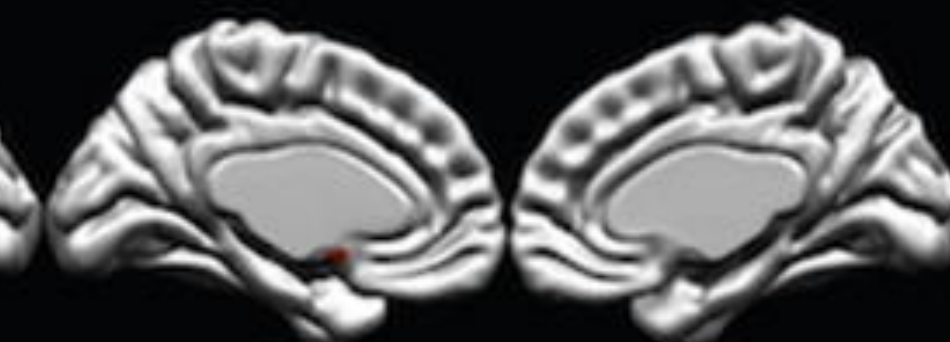

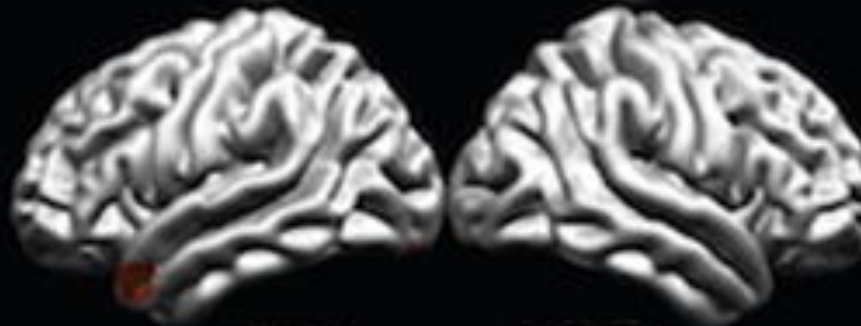

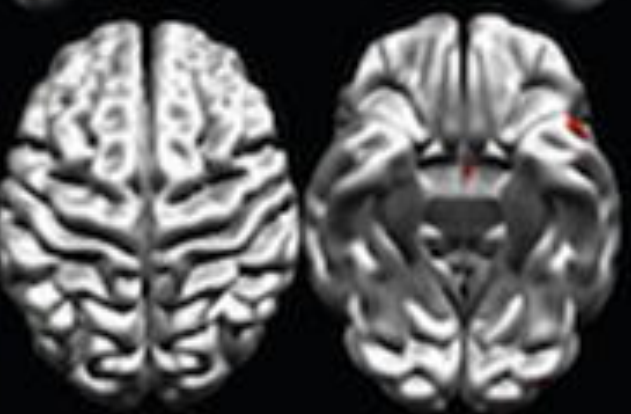

(⿻) 
bioRxiv preprint doi: https://doi.org/10.1101/306068; this version posted September 7, 2018. The copyright holder for this preprint (which was not certified by peer review) is the author/funder, who has granted bioRxiv a license to display the preprint in perpetuity. It is made available

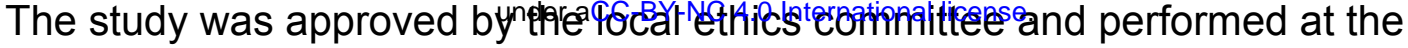

Instituto Nacional de Psiquiatría "Ramón de la Fuente Muñiz" in Mexico City, Mexico. The study was carried out according to the Declaration of Helsinki.

Participants provided verbal and written informed consent. 


\section{Figure 2}

Left Fusiform Gyrus

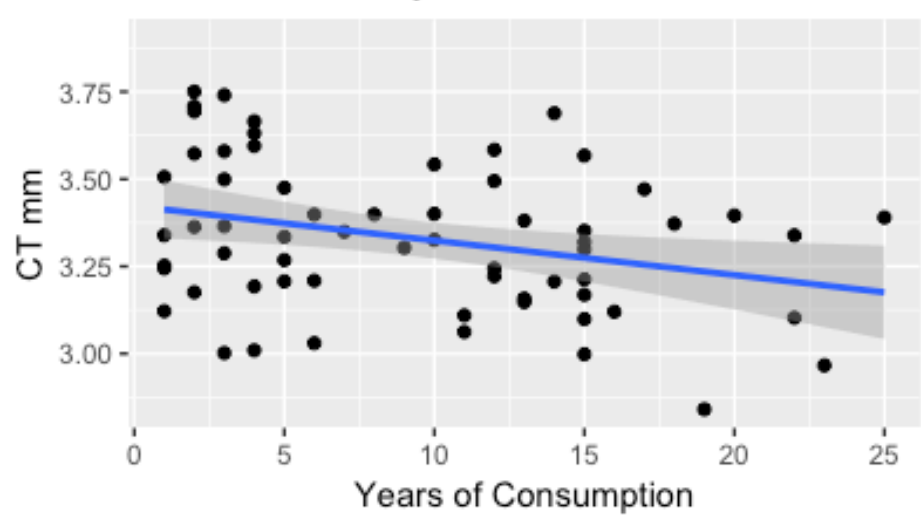

Left Middle Frontal Gyrus

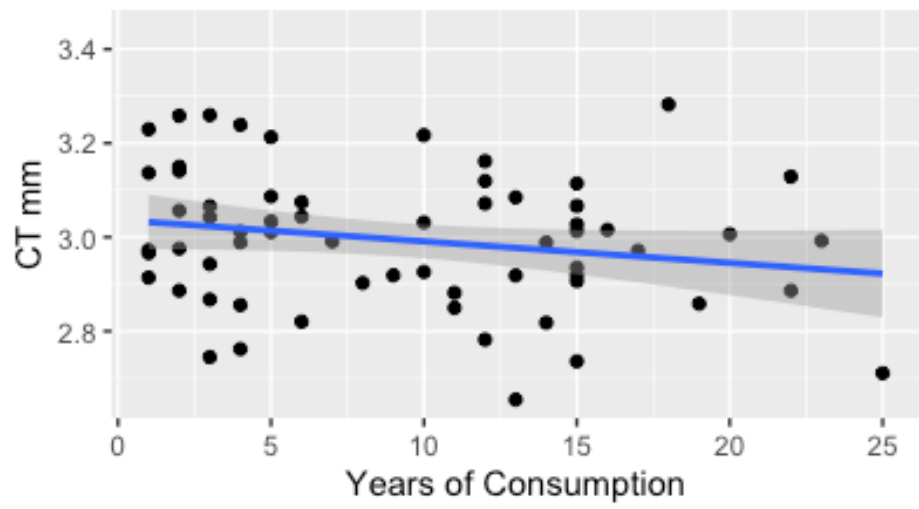

Left SMA

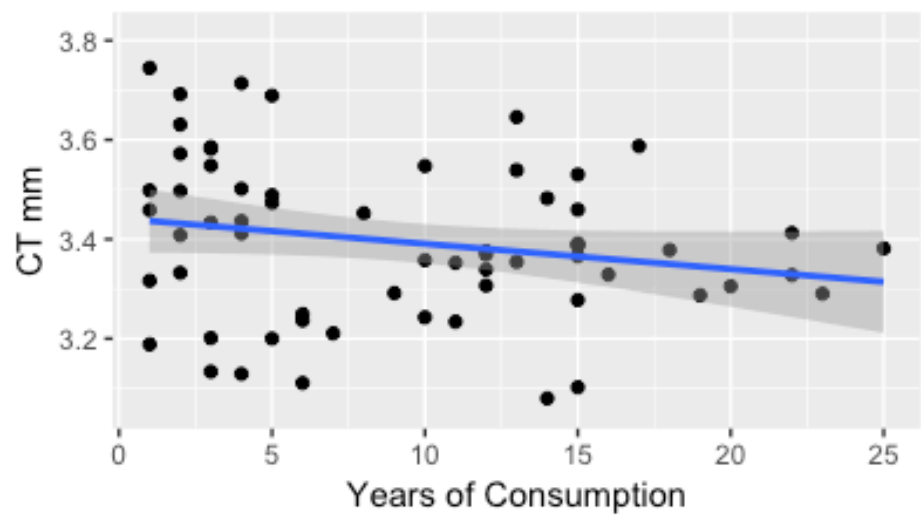

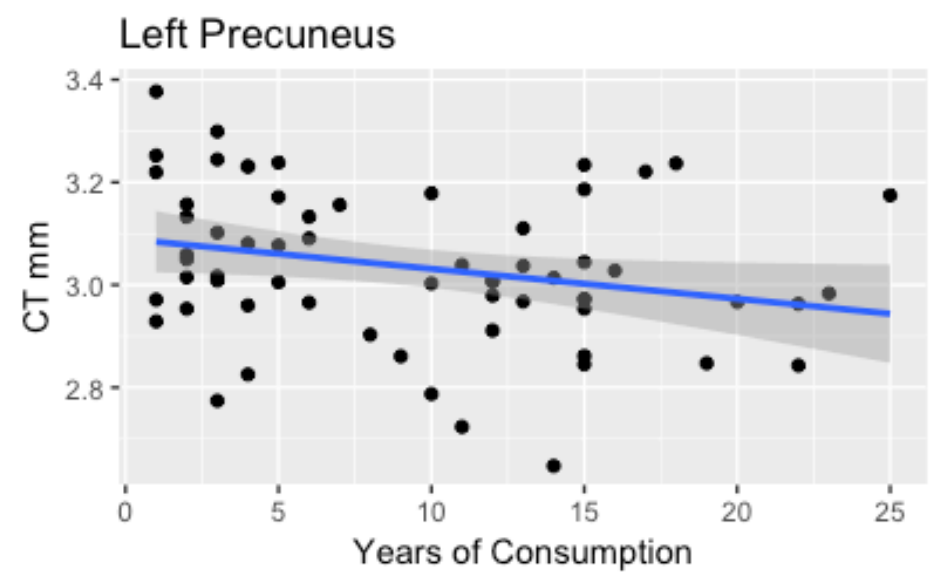

Left Insula

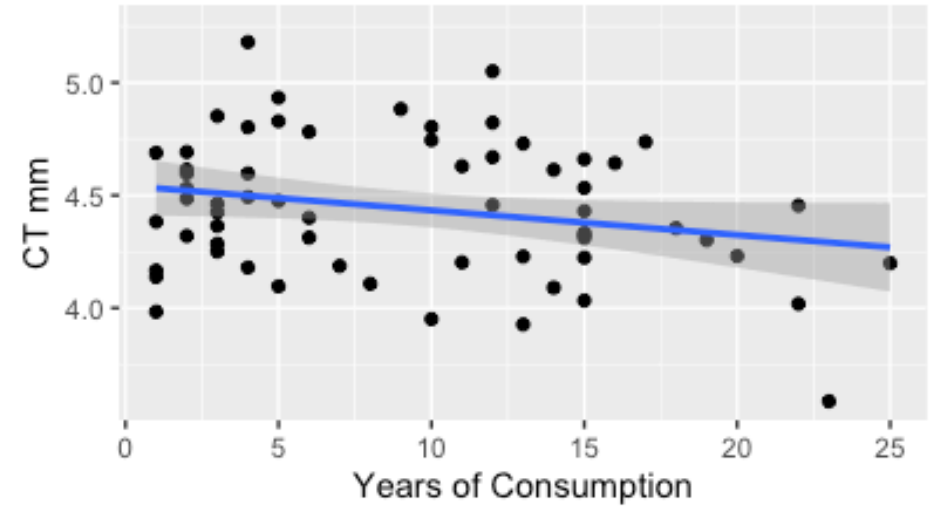


bioRxiv preprint doi: https://doi.org/10.1101/306068; this version posted September 7, 2018. The copyright holder for this preprint (which was not certified by peer review) is the author/funder, who has granted bioRxiv a license to display the preprint in perpetuity. It is made available under aCC-BY-NC 4.0 International license.

\section{Figure 3}

\section{Left Supramarginal Gyrus}

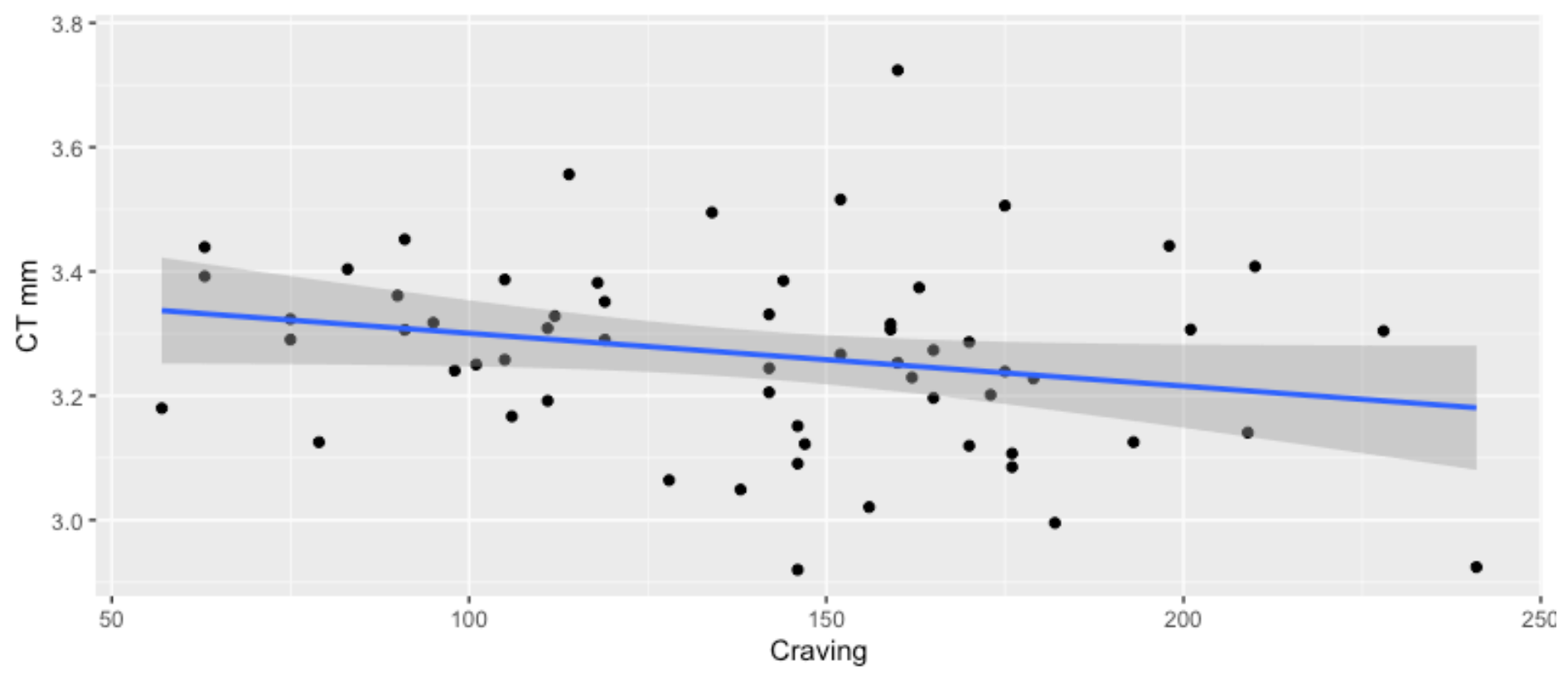

\section{Right Inferior Frontal Gyrus}

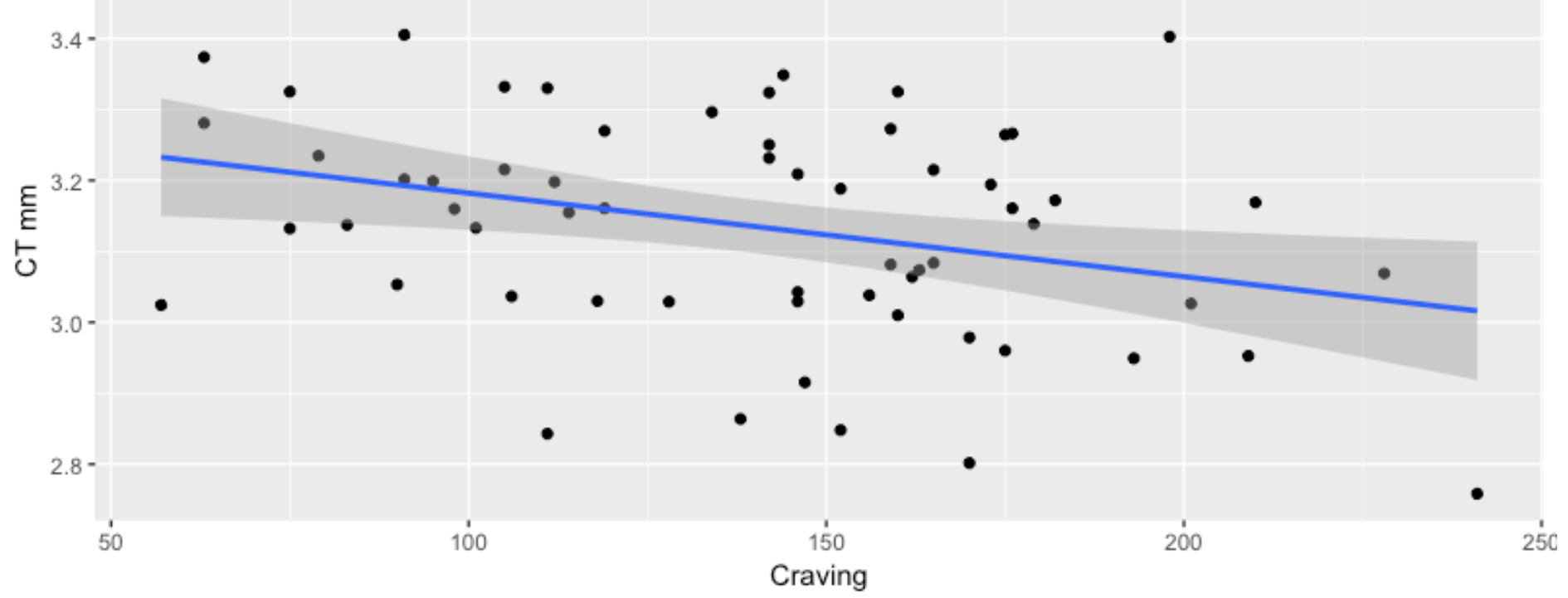


bioRxiv preprint doi: https://doi.org/10.1101/306068; this version posted September 7, 2018. The copyright holder for this preprint (which was not certified by peer review) is the author/funder, who has granted bioRxiv a license to display the preprint in perpetuity. It is made available under aCC-BY-NC 4.0 International license.

\section{Figure 4}

\section{Left Thalamus}

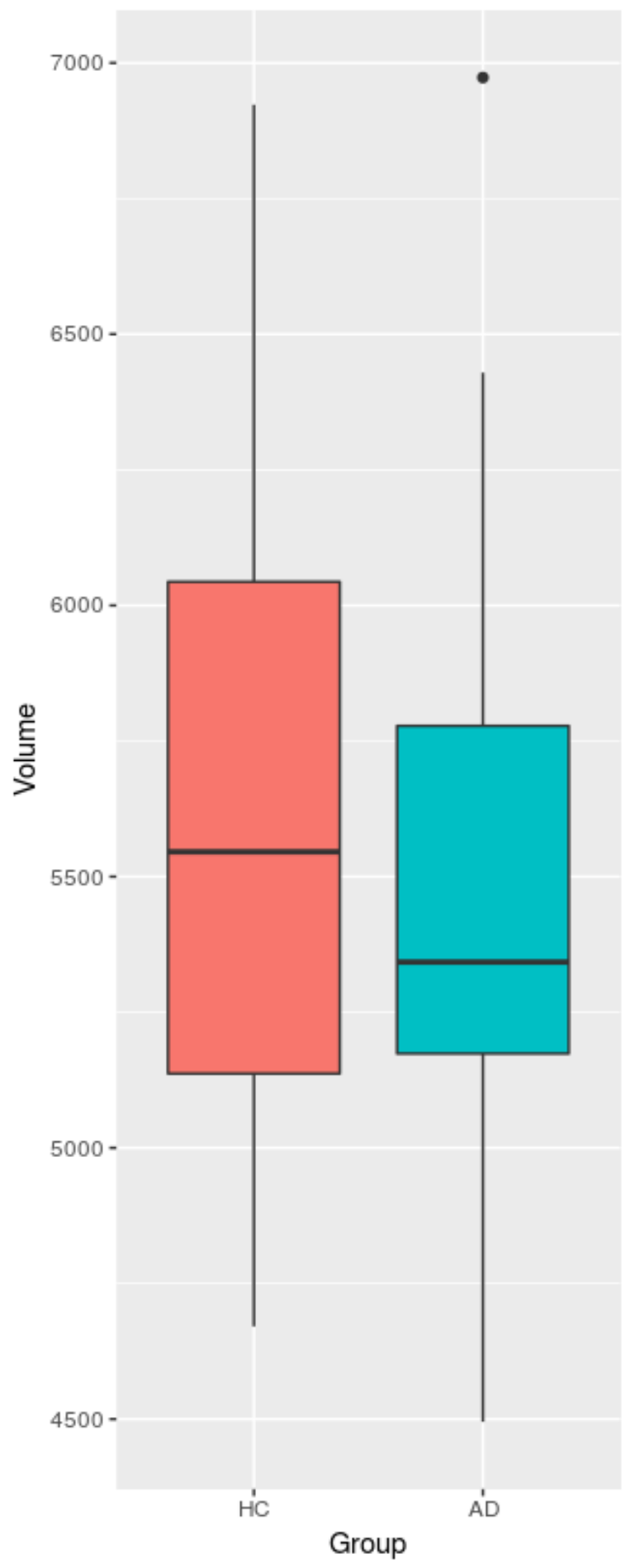

\section{Right Thalamus}

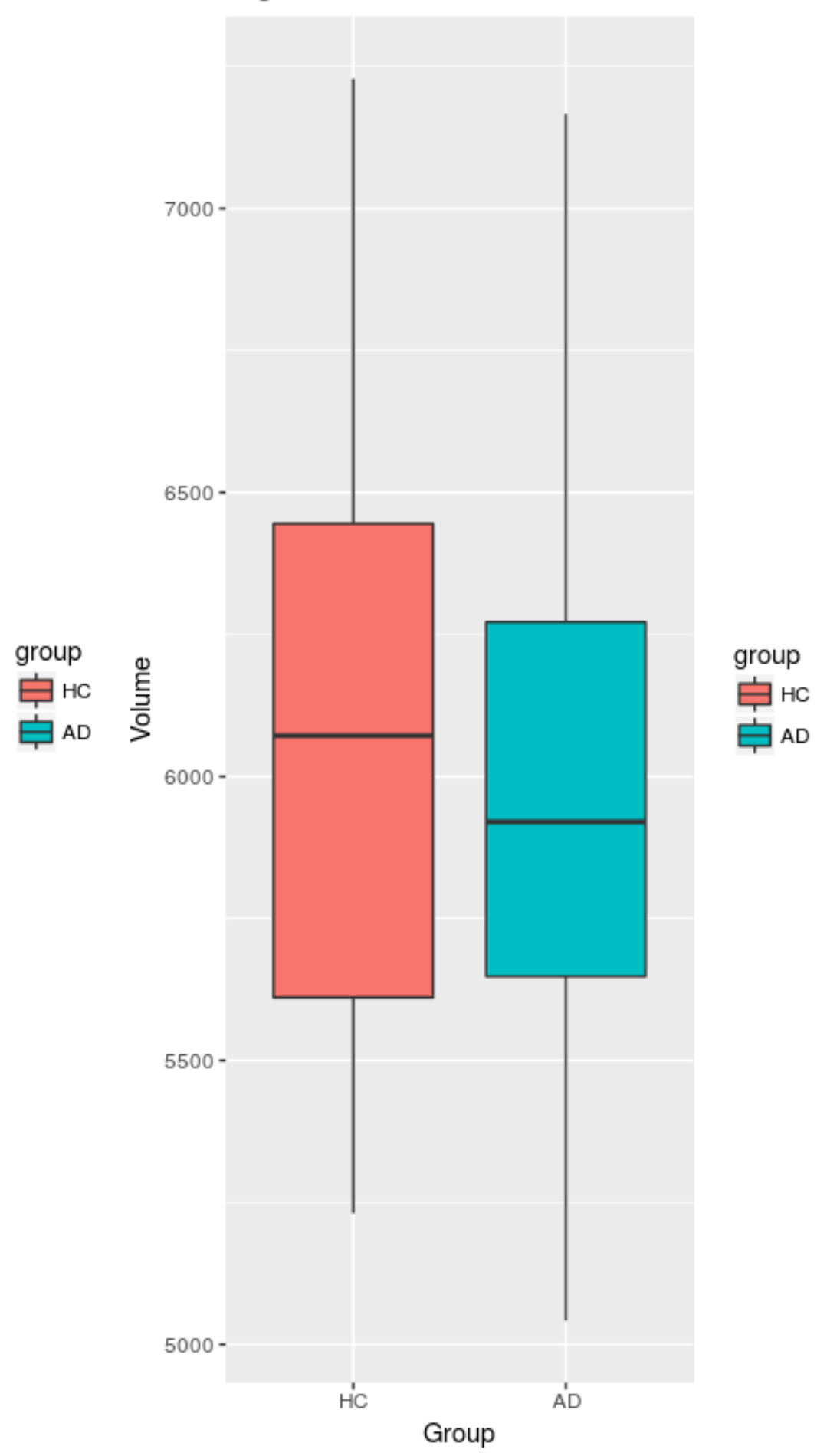




\section{ALL $\quad$ HC}

AD

\section{Left Striatum}

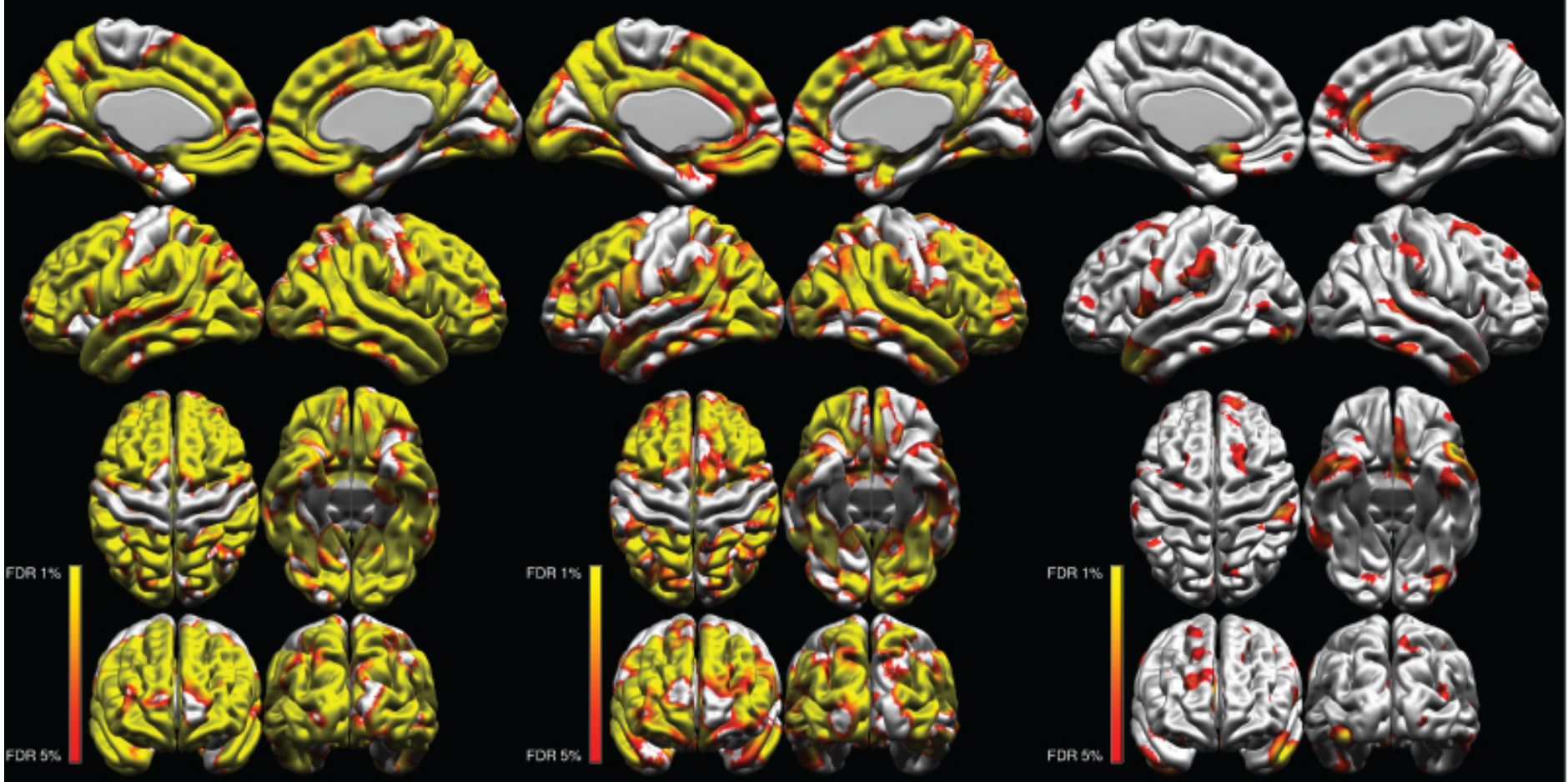

\section{Right Striatum}

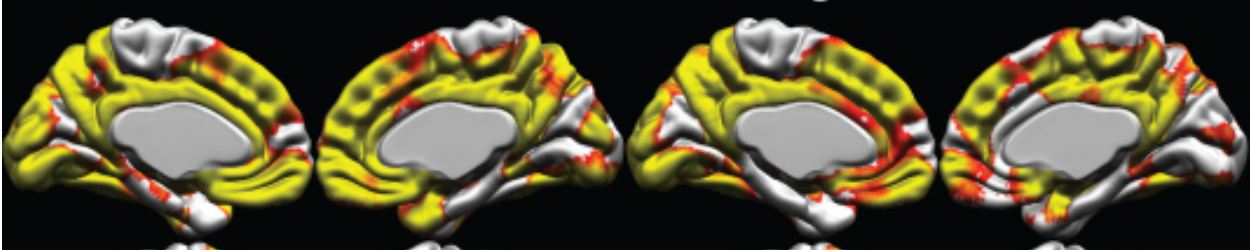

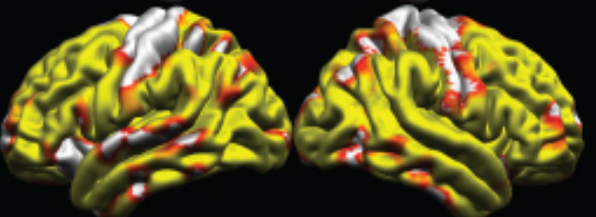
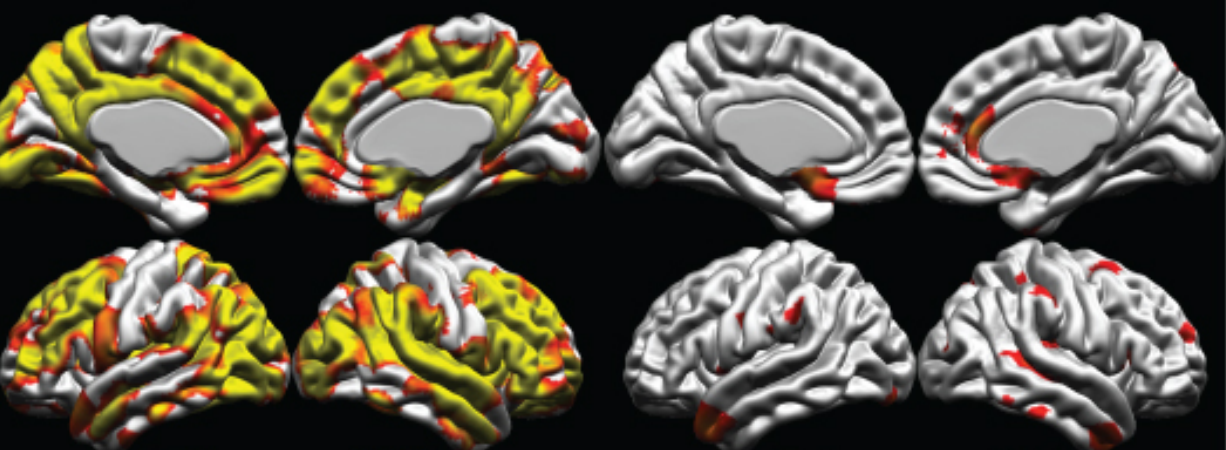

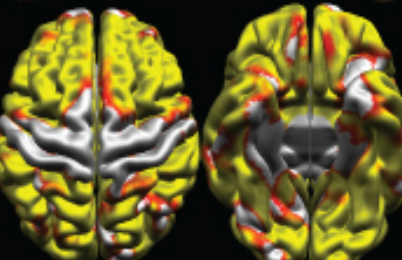
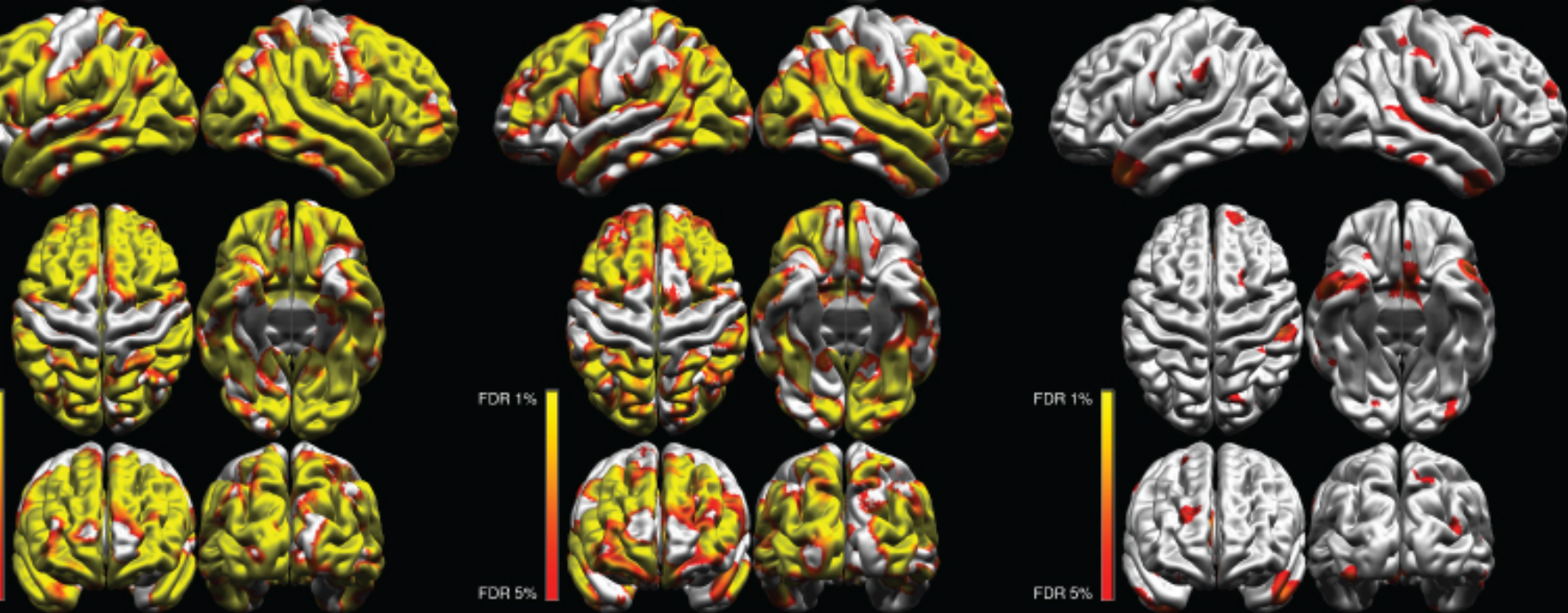
bioRxiv preprint doi: https://doi.org/10.1101/306068; this version posted September 7, 2018. The copyright holder for this preprint (which was not certified by peer review) is the author/funder, who has granted bioRxiv a license to display the preprint in perpetuity. It is made available

\section{Supplementary Figure" Le'gêned's}

Supplementary Figure 1. Voxel-based morphometry group contrast results $(\mathrm{CA}>\mathrm{HC})$.

Supplementary Figure 2. Scatterplots between CT peaks and years of consumption.

$\mathrm{CT}=$ Cortical thickness.

Supplementary Figure 3. Scatterplots between CT peaks and cocaine craving. $\mathrm{CT}=$ Cortical thickness.

Supplementary Figure 4. Boxplot of thalamus volume. $\mathrm{HC}=$ Healthy controls, $\mathrm{AD}=$ Cocaine addicts.

Supplementary Figure 5. Correlation of left striatum volume and right striatum volume with cortical thickness.

$\mathrm{HC}=$ Healthy controls, $\mathrm{AD}=$ Cocaine addicts, FDR $=$ False Discovery Rate . 
bioRxiv preprint doi: https://doi.org/10.1101/306068; this version posted September 7, 2018. The copyright holder for this preprint (which was not certified by peer review) is the author/funder, who has granted bioRxiv a license to display the preprint in perpetuity. It is made available

\section{Supplementary Figure" Le'gêned's}

Supplementary Figure 1. Voxel-based morphometry group contrast results $(\mathrm{CA}>\mathrm{HC})$.

Supplementary Figure 2. Scatterplots between CT peaks and years of consumption.

$\mathrm{CT}=$ Cortical thickness.

Supplementary Figure 3. Scatterplots between CT peaks and cocaine craving. $\mathrm{CT}=$ Cortical thickness.

Supplementary Figure 4. Boxplot of thalamus volume. $\mathrm{HC}=$ Healthy controls, $\mathrm{AD}=$ Cocaine addicts.

Supplementary Figure 5. Correlation of left striatum volume and right striatum volume with cortical thickness.

$\mathrm{HC}=$ Healthy controls, $\mathrm{AD}=$ Cocaine addicts, FDR $=$ False Discovery Rate . 
bioRxiv preprint doi: https://doi.org/10.1101/306068; this version posted September 7, 2018. The copyright holder for this preprint (which was not certified by peer review) is the author/funder, who has granted bioRxiv a license to display the preprint in perpetuity. It is made available

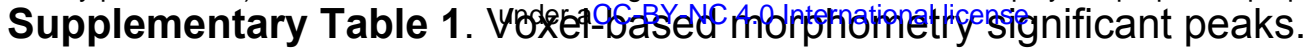

\begin{tabular}{|c|c|c|c|c|c|c|c|c|c|}
\hline Hem & Brain & Area & & & & $\mathbf{x}$ & y & $\mathbf{z}$ & $\mathbf{t}$ \\
\hline Left & Precentral & Gyrus & & & & -60 & 5 & 9 & -5.914 \\
\hline Left & Frontal & Pole & & & & -43 & 47 & 12 & -5.106 \\
\hline Left & Precentral & Gyrus & & & & -45 & -16 & 55 & -4.813 \\
\hline Left & Middle & Temporal & Gyrus & temporooccipital & part & -61 & -51 & 11 & -4.763 \\
\hline Left & Insular & Cortex & & & & -44 & 8 & -6 & -4.709 \\
\hline Left & Middle & Frontal & Gyrus & & & -44 & 31 & 33 & -4.509 \\
\hline Left & Paracingulate & Gyrus & & & & -7 & 24 & 32 & -4.507 \\
\hline Left & Frontal & Pole & & & & -50 & 37 & -3 & -4.469 \\
\hline Left & Angular & Gyrus & & & & -54 & -57 & 35 & -4.439 \\
\hline Left & Frontal & Pole & & & & -8 & 62 & 21 & -4.435 \\
\hline Left & Superior & Frontal & Gyrus & & & -27 & 11 & 59 & -4.385 \\
\hline Left & Precentral & Gyrus & & & & -54 & 4 & 38 & -4.345 \\
\hline Left & Middle & Frontal & Gyrus & & & -39 & 24 & 47 & -4.322 \\
\hline Left & Frontal & Pole & & & & -23 & 44 & 40 & -4.319 \\
\hline Left & Frontal & Pole & & & & -27 & 59 & 12 & -4.252 \\
\hline Left & Temporal & Pole & & & & -45 & 15 & -11 & -4.228 \\
\hline Left & Superior & Frontal & Gyrus & & & -6 & 40 & 48 & -4.217 \\
\hline Left & Angular & Gyrus & & & & -43 & -56 & 53 & -4.174 \\
\hline Left & Frontal & Pole & & & & -9 & 43 & 47 & -4.139 \\
\hline Left & Supramarginal & Gyrus & & anterior & division & -62 & -30 & 23 & -4.122 \\
\hline Left & Middle & Frontal & Gyrus & & & -42 & 2 & 55 & -4.098 \\
\hline Left & Frontal & Pole & & & & -28 & 44 & 35 & -4.065 \\
\hline Left & Middle & Frontal & Gyrus & & & -43 & 18 & 47 & -4.047 \\
\hline Left & Frontal & Pole & & & & -5 & 63 & -7 & -4.031 \\
\hline Left & Frontal & Pole & & & & -49 & 43 & -4 & -4.026 \\
\hline Left & Paracingulate & Gyrus & & & & -4 & 47 & -3 & -4.025 \\
\hline Left & Superior & Parietal & Lobule & & & -35 & -39 & 67 & -4.021 \\
\hline Left & Frontal & Pole & & & & -41 & 42 & 24 & -3.999 \\
\hline Left & Frontal & Pole & & & & -24 & 64 & 0 & -3.985 \\
\hline Left & Lateral & Occipital & Cortex & inferior & division & -36 & -90 & 3 & -3.978 \\
\hline Left & Lateral & Occipital & Cortex & superior & division & -35 & -67 & 56 & -3.889 \\
\hline
\end{tabular}


bioRxiv preprint doi: https://doi.org/10.1101/306068; this version posted September 7, 2018. The copyright holder for this preprint (which was not certified by peer review) is the author/funder, who has granted bioRxiv a license to display the preprint in perpetuity. It is made available

\begin{tabular}{|c|c|c|c|c|c|c|c|c|c|}
\hline Left & Occipital & Pole & under aC & -BY-NC 4.0 Intern & ational license & -24 & -102 & 1 & -3.877 \\
\hline Left & Middle & Frontal & Gyrus & & & -47 & 24 & 35 & -3.84 \\
\hline Left & Superior & Frontal & Gyrus & & & -10 & 38 & 51 & -3.819 \\
\hline Left & Lateral & Occipital & Cortex & superior & division & -39 & -63 & 58 & -3.808 \\
\hline Left & Frontal & Orbital & Cortex & & & -29 & 20 & -24 & -3.777 \\
\hline Left & Frontal & Pole & & & & -9 & 68 & 10 & -3.755 \\
\hline Left & Frontal & Pole & & & & -23 & 59 & 21 & -3.712 \\
\hline Left & Frontal & Pole & & & & -6 & 56 & 34 & -3.708 \\
\hline Left & Precentral & Gyrus & & & & -61 & -4 & 20 & -3.701 \\
\hline Left & Supramarginal & Gyrus & anterior & division & & -59 & -38 & 42 & -3.658 \\
\hline Left & Frontal & Pole & & & & -7 & 59 & 13 & -3.647 \\
\hline Left & Temporal & Occipital & Fusiform & & & -24 & -47 & -15 & -3.643 \\
\hline Left & Lingual & Gyrus & & & & -9 & -78 & 0 & -3.637 \\
\hline Left & Frontal & Pole & & & & -48 & 53 & -1 & -3.636 \\
\hline Left & Occipital & Pole & & & & -15 & -103 & 6 & -3.624 \\
\hline Left & Cingulate & Gyrus & anterior & division & & -4 & 40 & 13 & -3.623 \\
\hline Left & Superior & Frontal & Gyrus & & & -6 & 50 & 28 & -3.618 \\
\hline Left & Middle & Frontal & Gyrus & & & -47 & 7 & 48 & -3.612 \\
\hline Left & Frontal & Pole & & & & -5 & 59 & 4 & -3.562 \\
\hline Left & Cingulate & Gyrus & anterior & division & & -5 & 34 & 23 & -3.516 \\
\hline Left & Precentral & Gyrus & & & & -31 & -12 & 72 & -3.512 \\
\hline Left & Supramarginal & Gyrus & anterior & division & & -51 & -33 & 34 & -3.491 \\
\hline Left & Cingulate & Gyrus & anterior & division & & -5 & 35 & 21 & -3.48 \\
\hline Left & Inferior & Temporal & Gyrus & temporooccipital & part & -46 & -51 & -22 & -3.418 \\
\hline Left & Occipital & Pole & & & & -26 & -95 & -13 & -3.395 \\
\hline Left & Postcentral & Gyrus & & & & -47 & -29 & 62 & -3.381 \\
\hline Left & Frontal & Orbital & Cortex & & & -38 & 23 & -15 & -3.363 \\
\hline Left & Precuneus & Cortex & & & & -11 & -61 & 44 & 3.808 \\
\hline Right & Frontal & Pole & & & & 27 & 61 & 5 & -4.865 \\
\hline Right & Frontal & Pole & & & & 37 & 54 & 12 & -4.577 \\
\hline Right & Inferior & Frontal & Gyrus & pars & opercularis & 56 & 11 & 9 & -4.537 \\
\hline Right & Frontal & Pole & & & & 5 & 62 & 8 & -4.513 \\
\hline Right & Superior & Frontal & Gyrus & & & 18 & 32 & 52 & -4.482 \\
\hline Right & Frontal & Pole & & & & 9 & 54 & 36 & -4.447 \\
\hline
\end{tabular}


bioRxiv preprint doi: https://doi.org/10.1101/306068; this version posted September 7, 2018. The copyright holder for this preprint (which was not certified by peer review) is the author/funder, who has granted bioRxiv a license to display the preprint in perpetuity. It is made available

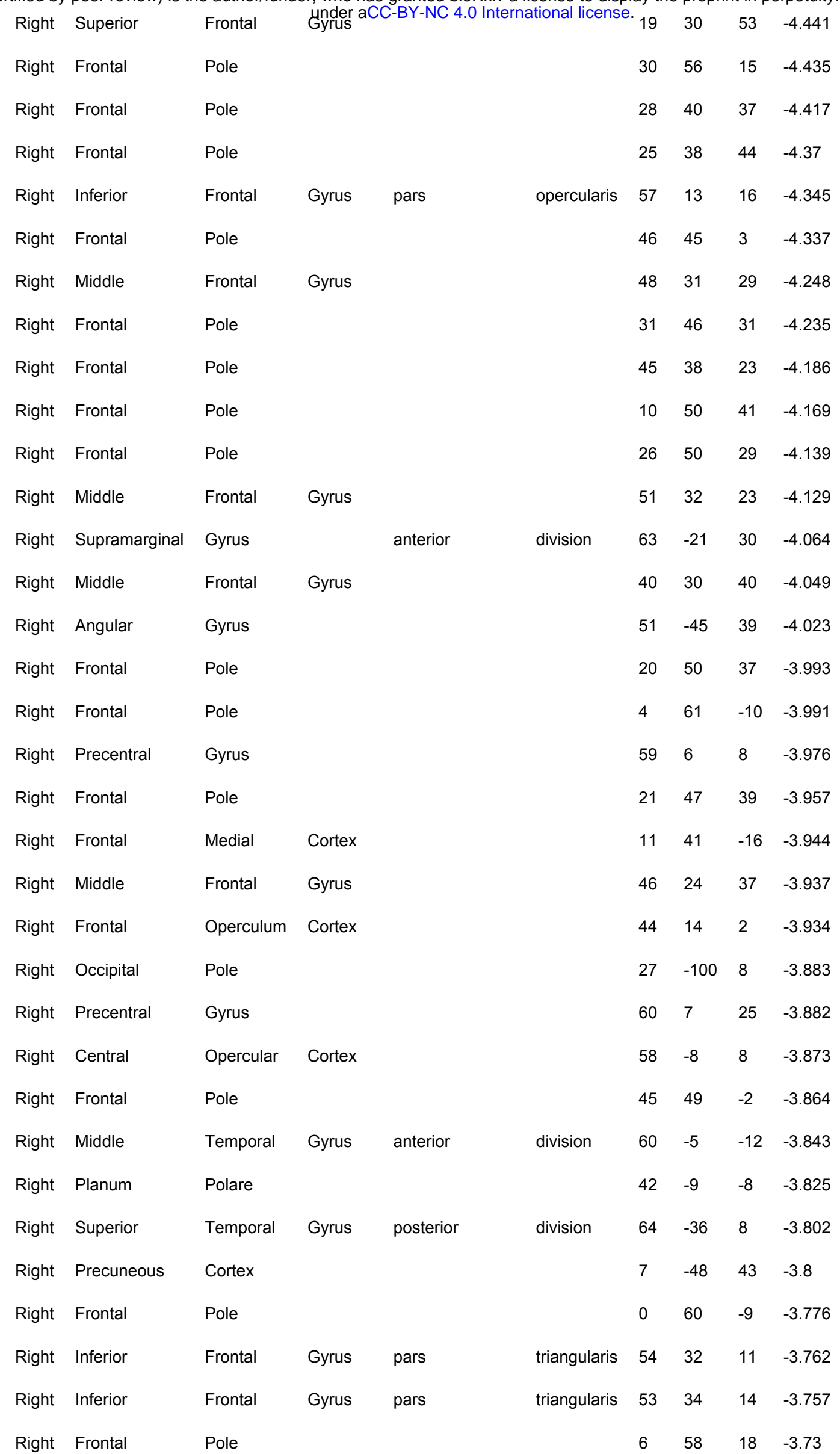


bioRxiv preprint doi: https://doi.org/10.1101/306068; this version posted September 7, 2018. The copyright holder for this preprint (which was not certified by peer review) is the author/funder, who has granted bioRxiv a license to display the preprint in perpetuity. It is made available

\begin{tabular}{|c|c|c|c|c|c|c|c|c|c|}
\hline Right & Frontal & Pole & & 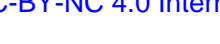 & ational IIcense & 23 & 65 & 13 & -3.722 \\
\hline Right & Inferior & Frontal & Gyrus & pars & opercularis & 56 & 21 & 10 & -3.643 \\
\hline Right & Frontal & Operculum & Cortex & & & 41 & 21 & -2 & -3.587 \\
\hline Right & Occipital & Fusiform & Gyrus & & & 20 & -72 & -11 & -3.578 \\
\hline Right & Middle & Temporal & Gyrus & posterior & division & 69 & -10 & -19 & -3.571 \\
\hline Right & Middle & Temporal & Gyrus & temporooccipital & part & 60 & -56 & -1 & -3.56 \\
\hline Right & Postcentral & Gyrus & & & & 43 & -21 & 51 & -3.504 \\
\hline Right & Precentral & Gyrus & & & & 56 & -1 & 40 & -3.494 \\
\hline Right & Superior & Temporal & Gyrus & anterior & division & 59 & 6 & -4 & -3.492 \\
\hline Right & Inferior & Temporal & Gyrus & posterior & division & 59 & -31 & -20 & -3.43 \\
\hline Right & Postcentral & Gyrus & & & & 43 & -22 & 65 & -3.413 \\
\hline Right & Lateral & Occipital & Cortex & inferior & division & 39 & -90 & -4 & -3.403 \\
\hline Right & Frontal & Pole & & & & 45 & 56 & -13 & -3.374 \\
\hline Right & Precentral & Gyrus & & & & 4 & -21 & 54 & -3.349 \\
\hline Right & Temporal & Pole & & & & 42 & 11 & -16 & -3.347 \\
\hline Right & Frontal & Pole & & & & 21 & 54 & -3 & 3.644 \\
\hline
\end{tabular}

Hem $=$ Hemisphere, $\mathrm{t}=\mathrm{t}$-value, coordinates are in MNI. 
bioRxiv preprint doi: https://doi.org/10.1101/306068; this version posted September 7, 2018. The copyright holder for this preprint (which was not certified by peer review) is the author/funder, who has granted bioRxiv a license to display the preprint in perpetuity. It is made available

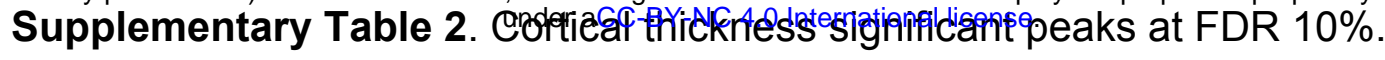

\begin{tabular}{|c|c|c|c|c|c|}
\hline Brain Areas & vertex & $\mathbf{x}$ & y & $\mathbf{z}$ & $\mathbf{t}$ \\
\hline Left Superior frontal gyrus, medial orbital & 17449 & -2 & 63 & -6 & -4.31 \\
\hline Left Postcentral gyrus & 21560 & -60 & 2 & 15 & -4.14 \\
\hline Left Rolandic operculum & 21525 & -60 & 4 & 14 & -4.03 \\
\hline Left Precentral gyrus & 21506 & -61 & 2 & 19 & -3.95 \\
\hline Left Superior frontal gyrus, dorsolateral & 4509 & -25 & 56 & 23 & -3.93 \\
\hline Left Superior frontal gyrus, medial & 27538 & -13 & 56 & 33 & -3.76 \\
\hline Left Middle temporal gyrus & 22615 & -53 & -48 & 14 & -3.61 \\
\hline Left Inferior frontal gyrus, orbital part & 3138 & -38 & 37 & -15 & -3.6 \\
\hline Left Fusiform gyrus & 36594 & -40 & -10 & -35 & -3.53 \\
\hline Left Middle frontal gyrus & 18317 & -37 & 53 & 22 & -3.52 \\
\hline Left Inferior temporal gyrus & 36593 & -40 & -9 & -35 & -3.5 \\
\hline Left Superior temporal gyrus & 22591 & -57 & -51 & 18 & -3.46 \\
\hline Left Supplementary motor area & 7066 & -2 & 30 & 49 & -3.34 \\
\hline Left Middle occipital gyrus & 33739 & -49 & -82 & -4 & -3.28 \\
\hline Left Inferior occipital gyrus & 35976 & -53 & -61 & -11 & -3.28 \\
\hline Left Precuneus & 31415 & -7 & -59 & 53 & -3.22 \\
\hline Left Gyrus Rectus & 16957 & -2 & 62 & -15 & -3.21 \\
\hline Left Median cingulate and paracingulate gyri & 28377 & -8 & 13 & 39 & -3.17 \\
\hline Left Calcarine fissure and surrounding cortex & 33121 & -11 & -106 & -1 & -3.1 \\
\hline Left Angular gyrus & 23260 & -51 & -54 & 28 & -3 \\
\hline Left Cuneus & 38907 & -20 & -51 & 0 & -2.98 \\
\hline Left Inferior frontal gyrus, triangular part & 19006 & -40 & 44 & 8 & -2.93 \\
\hline Left Supramarginal gyrus & 22145 & -56 & -20 & 22 & -2.83 \\
\hline Left Supeiror frontal gyrus, orbital part & 15296 & -13 & 23 & -20 & -2.81 \\
\hline Left Parahippocampal gyrus & 14365 & -25 & 2 & -25 & -2.81 \\
\hline Left Lingual gyrus & 2449 & -20 & -51 & 0 & -2.77 \\
\hline Left Inferior frontal gyrus, opercular part & 19986 & -56 & 22 & 16 & -2.76 \\
\hline Left Insula & 10363 & -43 & -6 & -2 & -2.73 \\
\hline Left Temporal pole: superior temporal gyrus & 14236 & -23 & 4 & -27 & -2.71 \\
\hline Left Olfactory Cortex & 16118 & -16 & 6 & -19 & -2.62 \\
\hline
\end{tabular}


bioRxiv preprint doi: https://doi.org/10.1101/306068; this version posted September 7, 2018. The copyright holder for this preprint (which was not certified by peer review) is the author/funder, who has granted bioRxiv a license to display the preprint in perpetuity. It is made available

\begin{tabular}{|c|c|c|c|c|c|}
\hline Left Superior parietal gyrus & 25046 & onal & -40 & 64 & -2.57 \\
\hline Left Anterior cingulate and paracingulate gyri & 28577 & -7 & 19 & 34 & -2.56 \\
\hline Left Superior occipital gyrus & 2121 & -25 & -96 & 4 & -2.48 \\
\hline Left Middle frontal gyrus orbital part & 19068 & -44 & 51 & 1 & -2.46 \\
\hline Left Paracentral lobule & 30828 & -3 & -36 & 54 & -2.44 \\
\hline Right Superior frontal gyrus, medial orbital & 17449 & -2 & 63 & -6 & -4.31 \\
\hline Right Rolandic operculum & 21560 & -60 & 2 & 15 & -4.14 \\
\hline Right Precentral gyrus & 21506 & -61 & 2 & 19 & -3.95 \\
\hline Right Superior frontal gyrus, dorsolateral & 4509 & -25 & 56 & 23 & -3.93 \\
\hline Right Superior frontal gyrus, medial & 17540 & -3 & 65 & -4 & -3.91 \\
\hline Right Postcentral gyrus & 5410 & -60 & 0 & 19 & -3.83 \\
\hline Right Middle frontal gyrus & 4523 & -24 & 51 & 21 & -3.81 \\
\hline Right Superior temporal gyrus & 22615 & -53 & -48 & 14 & -3.61 \\
\hline Right Inferior frontal gyrus, orbital part & 3138 & -38 & 37 & -15 & -3.6 \\
\hline Right Middle temporal gyrus & 36414 & -52 & -53 & 13 & -3.6 \\
\hline Right Fusiform gyrus & 36594 & -40 & -10 & -35 & -3.53 \\
\hline Right Inferior temporal gyrus & 36593 & -40 & -9 & -35 & -3.5 \\
\hline Right Middle occipital gyrus & 33739 & -49 & -82 & -4 & -3.28 \\
\hline Right Precuneus & 31415 & -7 & -59 & 53 & -3.22 \\
\hline Right Median cingulate and paracingulate gyri & 28373 & -8 & 14 & 39 & -3.18 \\
\hline Right Gyrus Rectus & 16956 & -2 & 63 & -17 & -3.14 \\
\hline Right Calcarine fissure and surrounding cortex & 33121 & -11 & -106 & -1 & -3.1 \\
\hline Right Supplementary motor area & 28356 & -7 & 15 & 39 & -3.09 \\
\hline Right Inferior occipital gyrus & 8459 & -46 & -80 & -7 & -3.04 \\
\hline Right Cuneus & 38907 & -20 & -51 & 0 & -2.98 \\
\hline Right Angular gyrus & 23257 & -50 & -54 & 29 & -2.96 \\
\hline Right Inferior frontal gyrus, triangular part & 19006 & -40 & 44 & 8 & -2.93 \\
\hline Right Superior parietal gyrus & 25062 & -18 & -40 & 72 & -2.93 \\
\hline Right Supramarginal gyrus & 22145 & -56 & -20 & 22 & -2.83 \\
\hline Right Superior frontal gyrus, orbital part & 15296 & -13 & 23 & -20 & -2.81 \\
\hline Right Parahippocampal gyrus & 14247 & -24 & 2 & -26 & -2.81 \\
\hline Right Temporal pole: superior temporal gyrus & 14365 & -25 & 2 & -25 & -2.81 \\
\hline Right Lingual gyrus & 2449 & -20 & -51 & 0 & -2.77 \\
\hline Right Inferior frontal gyrus, opercular part & 19986 & -56 & 22 & 16 & -2.76 \\
\hline
\end{tabular}


bioRxiv preprint doi: https://doi.org/10.1101/306068; this version posted September 7, 2018. The copyright holder for this preprint (which was not certified by peer review) is the author/funder, who has granted bioRxiv a license to display the preprint in perpetuity. It is made available

Right Insula under aCC-BY-NC 400 lnternational license.

$-2$

$-2.73$

Right Olfactory Cortex

16118

$-16 \quad 6$

$-19$

$-2.62$

Vertex $=$ vertex peak in MINC format, $\mathrm{t}=\mathrm{t}$-value. Coordinates in MNI. 
bioRxiv preprint doi: https://doi.org/10.1101/306068; this version posted September 7, 2018. The copyright holder for this preprint (which was not certified by peer review) is the author/funder, who has granted bioRxiv a license to display the preprint in perpetuity. It is made available

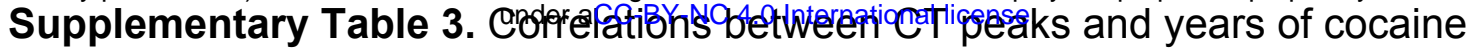
use.

\begin{tabular}{lllll} 
Brain Area & vertex & $\mathbf{r}$ & uncorr-p & fdr-p \\
\hline Left Fusiform Gyrus & 36594 & -0.35 & 0.003 & 0.02 \\
Left Middle Frontal Gyrus & 18317 & -0.20 & 0.057 & 0.057 \\
Left SMA & 7066 & -0.24 & 0.031 & 0.05 \\
Left Precuneus & 31415 & -0.22 & 0.047 & 0.057 \\
Left Insula & 10363 & -0.26 & 0.023 & 0.046
\end{tabular}

Vertex $=$ Surface vertex CIVET 1.1.12, $r=$ correlation coefficient, uncorr- $p=$ noncorrected $p$ value, fdr- $p=p$ value corrected for multiple comparisons using false discovery rate. 
bioRxiv preprint doi: https://doi.org/10.1101/306068; this version posted September 7, 2018. The copyright holder for this preprint (which was not certified by peer review) is the author/funder, who has granted bioRxiv a license to display the preprint in perpetuity. It is made available

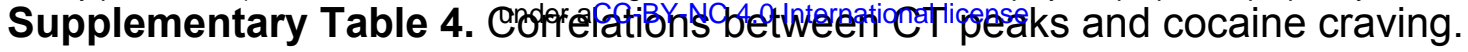

\begin{tabular}{lcccc} 
Brain Area & vertex & r & uncorr-p & fdr-p \\
\hline Left Supramarginal Gyrus & 22145 & -0.24 & 0.034 & 0.045 \\
Right Middle Frontal Gyrus & 18285 & -0.22 & 0.042 & 0.045 \\
Right Lingual Gyrus & 9552 & -0.22 & 0.045 & 0.045 \\
Right Parahippocampal Gyrus & 38137 & -0.24 & 0.033 & 0.045
\end{tabular}

Vertex = Surface vertex CIVET 1.1.12, $r=$ correlation coefficient, uncorr- $p=$ noncorrected $p$ value, fdr- $p=p$ value corrected for multiple comparisons using false discovery rate. 
bioRxiv preprint doi: https://doi.org/10.1101/306068; this version posted September 7, 2018. The copyright holder for this preprint (which was not certified by peer review) is the author/funder, who has granted bioRxiv a license to display the preprint in perpetuity. It is made available

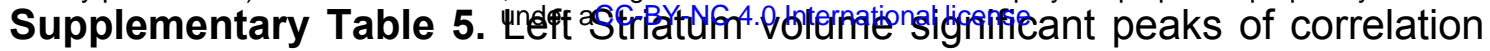
with cortical thickness in ALL participants.

\begin{tabular}{|c|c|c|c|c|c|}
\hline Brain Area & vertex & $\mathbf{x}$ & $\mathbf{y}$ & $\mathbf{z}$ & $\mathbf{t}$ \\
\hline Left Calcarine fissure and surrounding cortex & 33295 & -11 & -92 & -19 & 6 \\
\hline Left Olfactory Cortex & 4040 & -2 & 17 & -14 & 5.96 \\
\hline Left Lingual gyrus & 39387 & -12 & -87 & -20 & 5.91 \\
\hline Left Middle temporal gyrus & 13331 & -53 & 12 & -30 & 5.61 \\
\hline Left Anterior cingulate and paracingulate gyri & 16051 & -3 & 20 & -13 & 5.59 \\
\hline Left Superior temporal gyrus & 22384 & -45 & -34 & 17 & 5.5 \\
\hline Left Gyrus Rectus & 15115 & -6 & 39 & -28 & 5.39 \\
\hline Left Inferior occipital gyrus & 33480 & -34 & -90 & -10 & 5.3 \\
\hline Left Precuneus & 40676 & -13 & -52 & 2 & 5.3 \\
\hline Left Superior frontal gyrus, medial orbital & 15921 & -5 & 25 & -14 & 5.29 \\
\hline Left Middle occipital gyrus & 33446 & -33 & -93 & -10 & 5.23 \\
\hline Left Supramarginal gyrus & 22244 & -43 & -33 & 16 & 5.11 \\
\hline Left Rolandic operculum & 5493 & -37 & -26 & 19 & 5.07 \\
\hline Left Fusiform gyrus & 35422 & -40 & -75 & -16 & 5.01 \\
\hline Left Heschl gyrus & 672 & -39 & -31 & 18 & 5.01 \\
\hline Left Temporal pole: superior temporal gyrus & 13189 & -50 & 16 & -29 & 5 \\
\hline Left Temporal pole: middle temporal gyrus & 3348 & -49 & 14 & -32 & 4.99 \\
\hline
\end{tabular}


bioRxiv preprint doi: https://doi.org/10.1101/306068; this version posted September 7, 2018. The copyright holder for this preprint (which was not certified by peer review) is the author/funder, who has granted bioRxiv a license to display the preprint in perpetuity. It is made available

\begin{tabular}{|c|c|c|c|c|c|}
\hline Left Insula $\quad$ under aCC-BY-N & 1se. & -39 & -17 & 5 & 4.97 \\
\hline Left Precentral gyrus & 20887 & -53 & -5 & 30 & 4.96 \\
\hline Left Inferior frontal gyrus, opercular part & 20608 & -40 & 12 & 28 & 4.96 \\
\hline Left Angular gyrus & 23649 & -48 & -48 & 49 & 4.96 \\
\hline Left Middle frontal gyrus & 20597 & -39 & 11 & 28 & 4.94 \\
\hline Left Inferior frontal gyrus, triangular part & 20611 & -41 & 12 & 28 & 4.93 \\
\hline Left Cuneus & 38388 & -15 & -55 & 4 & 4.91 \\
\hline Left Superior frontal gyrus, dorsolateral & 6720 & -23 & -5 & 55 & 4.89 \\
\hline Left Inferior parietal, but supramarginal and angular gyri & 23531 & -47 & -47 & 47 & 4.75 \\
\hline Left Median cingulate and paracingulate gyri & 7483 & -5 & -18 & 44 & 4.66 \\
\hline Left Postcentral gyrus & 20865 & -53 & -6 & 29 & 4.66 \\
\hline Left Supplementary motor area & 1772 & -8 & 3 & 45 & 4.54 \\
\hline Left Superior frontal gyrus, medial & 28049 & -4 & 42 & 35 & 4.32 \\
\hline Left Posterior cingulate gyrus & 40909 & -2 & -52 & 16 & 4.31 \\
\hline Left Superior occipital gyrus & 33893 & -27 & -85 & 21 & 4.28 \\
\hline Left Inferior temporal gyrus & 36703 & -45 & -24 & -26 & 4.17 \\
\hline Left Superior parietal gyrus & 25063 & -29 & -40 & 59 & 4.13 \\
\hline Left Middle frontal gyrus orbital part & 19079 & -42 & 52 & 1 & 4.1 \\
\hline Left Supeiror frontal gyrus, orbital part & 15206 & -10 & 40 & -23 & 3.88 \\
\hline
\end{tabular}


bioRxiv preprint doi: https://doi.org/10.1101/306068; this version posted September 7, 2018. The copyright holder for this preprint (which was not certified by peer review) is the author/funder, who has granted bioRxiv a license to display the preprint in perpetuity. It is made available

\begin{tabular}{|c|c|c|c|c|c|}
\hline Left Paracentral lobule $\quad$ under a & רse. & -13 & -44 & 62 & 3.79 \\
\hline Left Parahippocampal gyrus & 37578 & -30 & -50 & -8 & 3.57 \\
\hline Left Inferior frontal gyrus, orbital part & 18643 & -39 & 52 & -13 & 3.45 \\
\hline Right Rolandic operculum & 21843 & -40 & -24 & 18 & 6.22 \\
\hline Right Superior temporal gyrus & 13008 & -45 & -2 & -11 & 6.02 \\
\hline Right Anterior cingulate and paracingulate gyri & 16045 & -3 & 16 & -14 & 5.99 \\
\hline Right Supramarginal gyrus & 21832 & -42 & -25 & 19 & 5.97 \\
\hline Right Inferior frontal gyrus, triangular part & 19447 & -42 & 22 & 7 & 5.8 \\
\hline Right Olfactory Cortex & 16042 & -3 & 15 & -15 & 5.79 \\
\hline Right Heschl gyrus & 10642 & -40 & -30 & 15 & 5.79 \\
\hline Right Insula & 10569 & -36 & -23 & 16 & 5.73 \\
\hline Right Middle occipital gyrus & 34433 & -41 & -88 & 13 & 5.65 \\
\hline Right Median cingulate and paracingulate gyri & 29837 & -11 & -21 & 41 & 5.58 \\
\hline Right Postcentral gyrus & 21790 & -47 & -16 & 15 & 5.52 \\
\hline Right Temporal pole: superior temporal gyrus & 3279 & -45 & 5 & -14 & 5.47 \\
\hline Right Superior frontal gyrus, medial & 4440 & -4 & 52 & 25 & 5.4 \\
\hline Right Inferior frontal gyrus, opercular part & 19526 & -42 & 20 & 7 & 5.39 \\
\hline Right Middle temporal gyrus & 11030 & -55 & -18 & -8 & 5.36 \\
\hline Right Superior occipital gyrus & 34019 & -26 & -84 & 18 & 5.26 \\
\hline
\end{tabular}


bioRxiv preprint doi: https://doi.org/10.1101/306068; this version posted September 7, 2018. The copyright holder for this preprint (which was not certified by peer review) is the author/funder, who has granted bioRxiv a license to display the preprint in perpetuity. It is made available

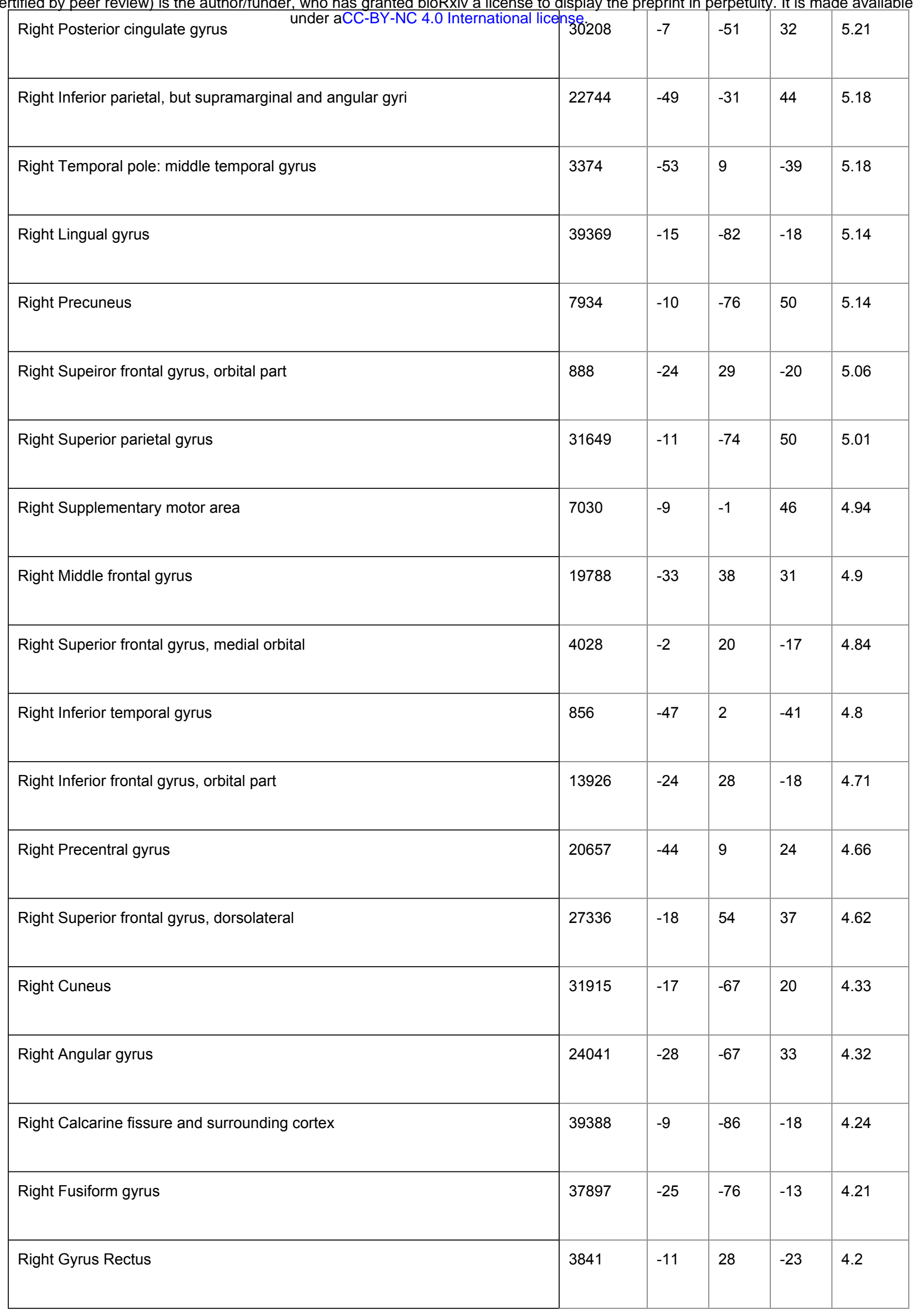


bioRxiv preprint doi: https://doi.org/10.1101/306068; this version posted September 7, 2018. The copyright holder for this preprint (which was not certified by peer review) is the author/funder, who has granted bioRxiv a license to display the preprint in perpetuity. It is made available

\begin{tabular}{|c|c|c|c|c|c|}
\hline Right Paracentral lobule & under aCC-BY-NC 4.0 International license. 1862 & -9 & -26 & 46 & 3.98 \\
\hline Right Middle frontal gyrus orbital part & 18535 & -23 & 54 & -15 & 3.79 \\
\hline Right Inferior occipital gyrus & 33607 & -35 & -91 & -7 & 3.78 \\
\hline Right Parahippocampal gyrus & 14247 & -24 & 2 & -26 & 3.65 \\
\hline
\end{tabular}

Supplementary Table 6. Right Striatum volume significant peaks of correlation with cortical thickness in ALL participants.

\begin{tabular}{|c|c|c|c|c|c|}
\hline Brain Area & vertex & $\mathbf{x}$ & $y$ & $\mathbf{z}$ & $\mathbf{t}$ \\
\hline Left Calcarine fissure and surrounding cortex & 33295 & -11 & -92 & -19 & 6.02 \\
\hline Left Olfactory Cortex & 16045 & -3 & 16 & -14 & 5.9 \\
\hline Left Lingual gyrus & 39387 & -12 & -87 & -20 & 5.84 \\
\hline Left Anterior cingulate and paracingulate gyri & 16051 & -3 & 20 & -13 & 5.33 \\
\hline Left Precuneus & 10176 & -12 & -52 & 3 & 5.29 \\
\hline Left Superior frontal gyrus, medial orbital & 16931 & -4 & 57 & -14 & 5.25 \\
\hline Left Middle temporal gyrus & 13331 & -53 & 12 & -30 & 5.22 \\
\hline Left Gyrus Rectus & 16932 & -3 & 58 & -15 & 5.16 \\
\hline Left Superior temporal gyrus & 22384 & -45 & -34 & 17 & 4.98 \\
\hline Left Insula & 10525 & -39 & -17 & 5 & 4.96 \\
\hline Left Middle occipital gyrus & 537 & -33 & -92 & -10 & 4.93 \\
\hline Left Inferior occipital gyrus & 33480 & -34 & -90 & -10 & 4.93 \\
\hline
\end{tabular}


bioRxiv preprint doi: https://doi.org/10.1101/306068; this version posted September 7, 2018. The copyright holder for this preprint (which was not certified by peer review) is the author/funder, who has granted bioRxiv a license to display the preprint in perpetuity. It is made available

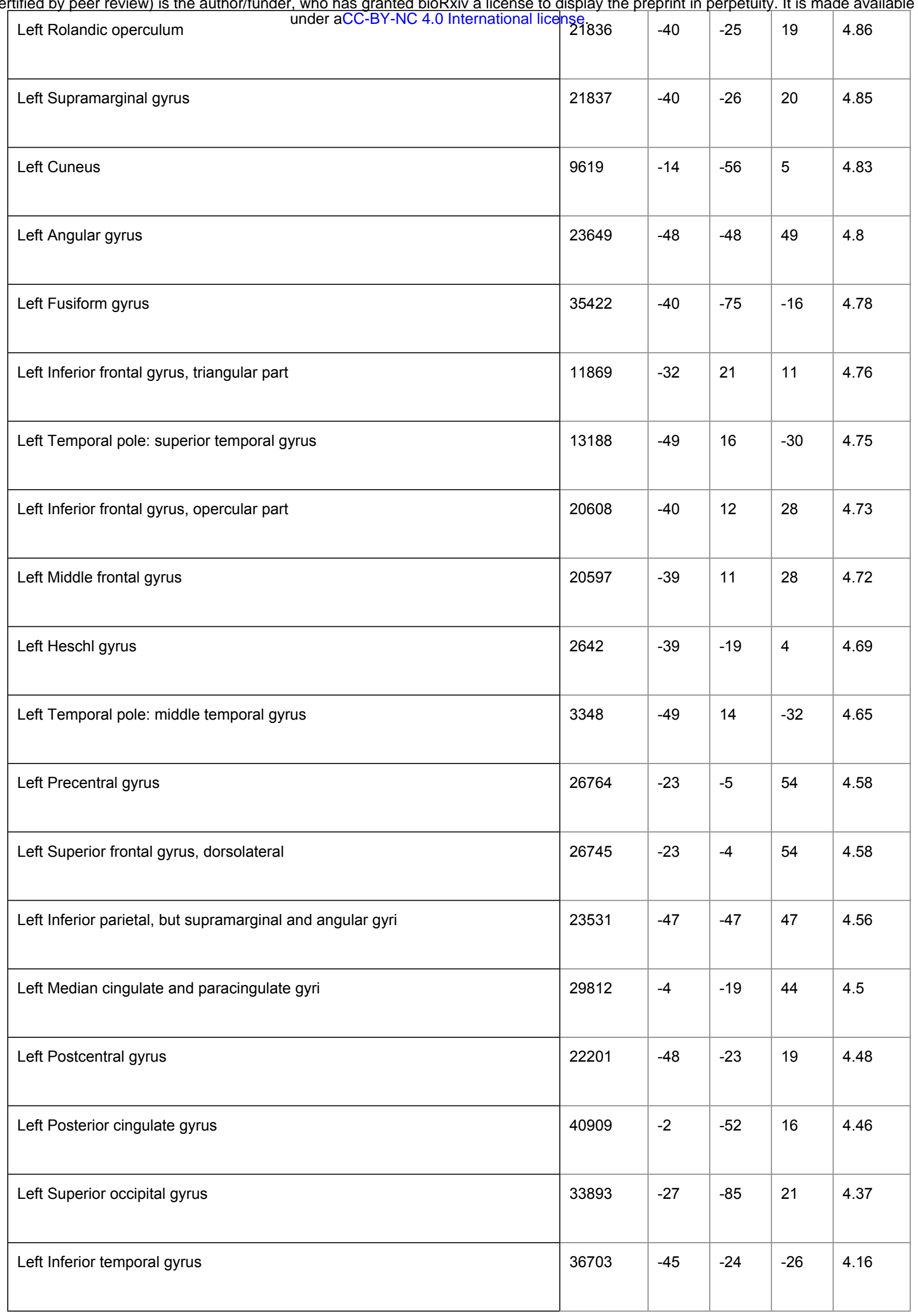


bioRxiv preprint doi: https://doi.org/10.1101/306068; this version posted September 7, 2018. The copyright holder for this preprint (which was not certified by peer review) is the author/funder, who has granted bioRxiv a license to display the preprint in perpetuity. It is made available

\begin{tabular}{|c|c|c|c|c|c|}
\hline Left Superior frontal gyrus, medial under a & 7043 & -5 & 43 & 34 & 4.1 \\
\hline Left Supplementary motor area & 1772 & -8 & 3 & 45 & 4.06 \\
\hline Left Superior parietal gyrus & 23435 & -32 & -55 & 43 & 3.97 \\
\hline Left Middle frontal gyrus orbital part & 18981 & -33 & 58 & 3 & 3.78 \\
\hline Left Supeiror frontal gyrus, orbital part & 15200 & -11 & 37 & -23 & 3.71 \\
\hline Left Paracentral lobule & 30979 & -13 & -44 & 62 & 3.45 \\
\hline Left Parahippocampal gyrus & 37578 & -30 & -50 & -8 & 3.4 \\
\hline Left Inferior frontal gyrus, orbital part & 18643 & -39 & 52 & -13 & 3.19 \\
\hline Right Anterior cingulate and paracingulate gyri & 16045 & -3 & 16 & -14 & 6.17 \\
\hline Right Olfactory Cortex & 16042 & -3 & 15 & -15 & 5.99 \\
\hline Right Rolandic operculum & 21843 & -40 & -24 & 18 & 5.98 \\
\hline Right Middle occipital gyrus & 34433 & -41 & -88 & 13 & 5.86 \\
\hline Right Supramarginal gyrus & 21837 & -40 & -26 & 20 & 5.77 \\
\hline Right Superior temporal gyrus & 13008 & -45 & -2 & -11 & 5.68 \\
\hline Right Median cingulate and paracingulate gyri & 29682 & -2 & -2 & 44 & 5.59 \\
\hline Right Heschl gyrus & 10639 & -39 & -30 & 17 & 5.59 \\
\hline Right Inferior frontal gyrus, triangular part & 19447 & -42 & 22 & 7 & 5.57 \\
\hline Right Insula & 10569 & -36 & -23 & 16 & 5.47 \\
\hline Right Superior occipital gyrus & 34019 & -26 & -84 & 18 & 5.28 \\
\hline
\end{tabular}


bioRxiv preprint doi: https://doi.org/10.1101/306068; this version posted September 7, 2018. The copyright holder for this preprint (which was not certified by peer review) is the author/funder, who has granted bioRxiv a license to display the preprint in perpetuity. It is made available

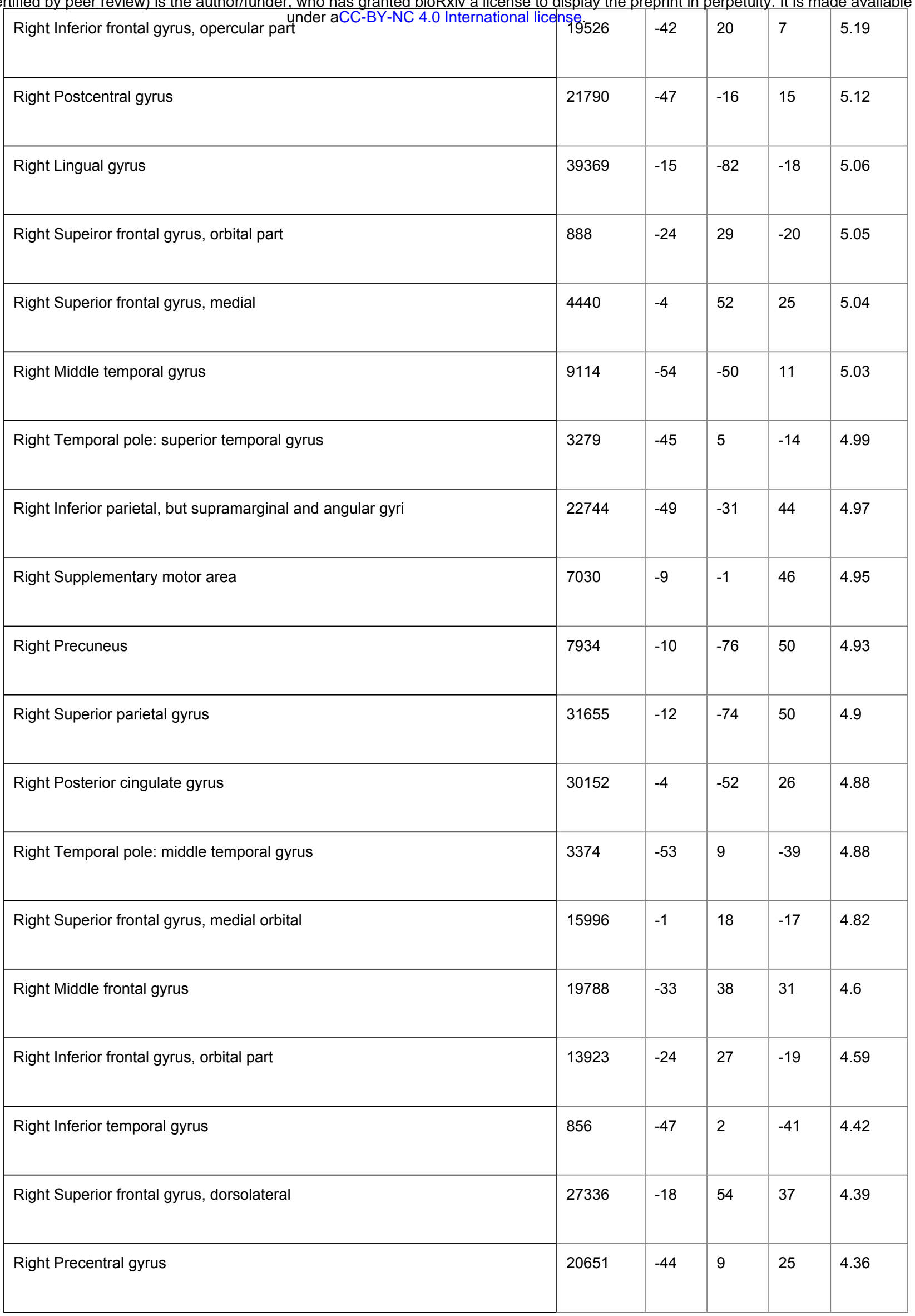


bioRxiv preprint doi: https://doi.org/10.1101/306068; this version posted September 7, 2018. The copyright holder for this preprint (which was not certified by peer review) is the author/funder, who has granted bioRxiv a license to display the preprint in perpetuity. It is made available

\begin{tabular}{|c|c|c|c|c|c|}
\hline Right Cuneus under a & 'șe. & -17 & -67 & 20 & 4.19 \\
\hline Right Fusiform gyrus & 9422 & -35 & -54 & -19 & 4.16 \\
\hline Right Angular gyrus & 24041 & -28 & -67 & 33 & 4.15 \\
\hline Right Calcarine fissure and surrounding cortex & 39388 & -9 & -86 & -18 & 4.05 \\
\hline Right Gyrus Rectus & 3841 & -11 & 28 & -23 & 4.02 \\
\hline Right Paracentral lobule & 1862 & -9 & -26 & 46 & 3.91 \\
\hline Right Inferior occipital gyrus & 33607 & -35 & -91 & -7 & 3.85 \\
\hline Right Middle frontal gyrus orbital part & 18538 & -23 & 51 & -14 & 3.74 \\
\hline Right Parahippocampal gyrus & 14247 & -24 & 2 & -26 & 3.55 \\
\hline
\end{tabular}

Supplementary Table 7. Left Striatum volume significant peaks of correlation with cortical thickness in $\mathrm{HC}$.

\begin{tabular}{|c|c|c|c|c|c|}
\hline Brain Areas & vertex & $\mathbf{x}$ & $\mathbf{y}$ & $\mathbf{z}$ & $\mathbf{t}$ \\
\hline Left Calcarine fissure and surrounding cortex & 33295 & -11 & -92 & -19 & 5.93 \\
\hline Left Precuneus & 30271 & -1 & -61 & 23 & 5.73 \\
\hline Left Lingual gyrus & 39387 & -12 & -87 & -20 & 5.69 \\
\hline Left Inferior frontal gyrus, triangular part & 19963 & -44 & 29 & 22 & 5.6 \\
\hline Left Superior frontal gyrus, medial orbital & 16899 & -5 & 56 & -14 & 5.55 \\
\hline Left Median cingulate and paracingulate gyri & 30717 & -5 & -41 & 48 & 5.44 \\
\hline Left Inferior frontal gyrus, opercular part & 20043 & -50 & 13 & 24 & 5.26 \\
\hline
\end{tabular}


bioRxiv preprint doi: https://doi.org/10.1101/306068; this version posted September 7, 2018. The copyright holder for this preprint (which was not certified by peer review) is the author/funder, who has granted bioRxiv a license to display the preprint in perpetuity. It is made available

\begin{tabular}{|c|c|c|c|c|c|}
\hline Left Middle frontal gyrus & under aCC-BY-NC 4.0 International license. 20500 & -44 & 21 & 28 & 5.25 \\
\hline Left Middle occipital gyrus & 8937 & -44 & -67 & -4 & 4.97 \\
\hline Left Gyrus Rectus & 4261 & -4 & 56 & -15 & 4.94 \\
\hline Left Inferior occipital gyrus & 35622 & -45 & -66 & -5 & 4.88 \\
\hline Left Fusiform gyrus & 9424 & -37 & -57 & -20 & 4.82 \\
\hline Left Supplementary motor area & 27985 & -5 & 4 & 47 & 4.68 \\
\hline Left Superior parietal gyrus & 25164 & -23 & -41 & 63 & 4.61 \\
\hline Left Superior frontal gyrus, dorsolateral & 26093 & -21 & 27 & 59 & 4.54 \\
\hline Left Precentral gyrus & 20657 & -44 & 9 & 24 & 4.49 \\
\hline Left Superior temporal gyrus & 22415 & -51 & -36 & 20 & 4.34 \\
\hline Left Postcentral gyrus & 25162 & -21 & -42 & 64 & 4.3 \\
\hline Left Superior frontal gyrus, medial & 444 & -8 & 53 & 43 & 4.24 \\
\hline Left Posterior cingulate gyrus & 30229 & -3 & -53 & 19 & 4.23 \\
\hline Left Supramarginal gyrus & 22367 & -51 & -38 & 24 & 4.2 \\
\hline Left Superior occipital gyrus & 32420 & -29 & -86 & 29 & 4.18 \\
\hline Left Middle temporal gyrus & 34871 & -51 & -55 & 15 & 4.18 \\
\hline Left Cuneus & 9614 & -18 & -53 & 1 & 4.14 \\
\hline Left Angular gyrus & 5941 & -45 & -48 & 47 & 4.05 \\
\hline Left Insula & 664 & -39 & -18 & 6 & 4.04 \\
\hline
\end{tabular}


bioRxiv preprint doi: https://doi.org/10.1101/306068; this version posted September 7, 2018. The copyright holder for this preprint (which was not certified by peer review) is the author/funder, who has granted bioRxiv a license to display the preprint in perpetuity. It is made available

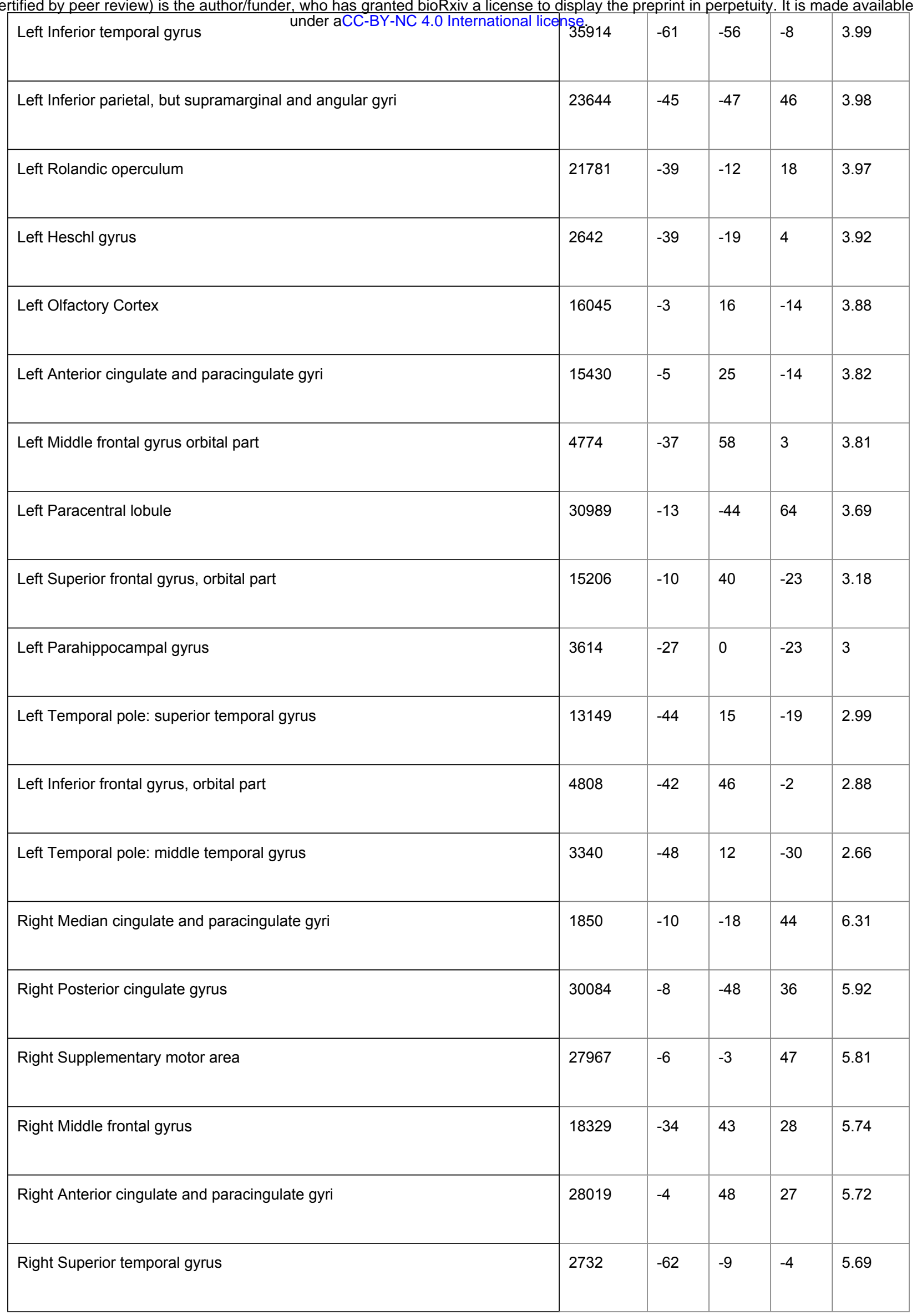


bioRxiv preprint doi: https://doi.org/10.1101/306068; this version posted September 7, 2018. The copyright holder for this preprint (which was not certified by peer review) is the author/funder, who has granted bioRxiv a license to display the preprint in perpetuity. It is made available

\begin{tabular}{|c|c|c|c|c|c|}
\hline Right Paracentral lobule unc & 1še. 2929 & -8 & -25 & 46 & 5.67 \\
\hline Right Superior frontal gyrus, medial & 27624 & -4 & 50 & 28 & 5.64 \\
\hline Right Supramarginal gyrus & 22224 & -45 & -29 & 16 & 5.61 \\
\hline Right Precuneus & 30434 & -9 & -52 & 35 & 5.53 \\
\hline Right Inferior frontal gyrus, triangular part & 19399 & -54 & 32 & 9 & 5.4 \\
\hline Right Middle occipital gyrus & 34407 & -43 & -83 & 13 & 5.36 \\
\hline Right Superior frontal gyrus, orbital part & 13954 & -23 & 36 & -24 & 5.17 \\
\hline Right Rolandic operculum & 21834 & -43 & -24 & 19 & 5.02 \\
\hline Right Heschl gyrus & 11075 & -44 & -30 & 11 & 5 \\
\hline Right Olfactory Cortex & 16042 & -3 & 15 & -15 & 4.97 \\
\hline Right Middle temporal gyrus & 10914 & -55 & -5 & -14 & 4.93 \\
\hline Right Superior occipital gyrus & 34045 & -31 & -77 & 20 & 4.85 \\
\hline Right Lingual gyrus & 39373 & -14 & -83 & -18 & 4.83 \\
\hline Right Superior frontal gyrus, medial orbital & 17547 & -7 & 72 & -6 & 4.74 \\
\hline Right Insula & 2591 & -38 & -11 & 16 & 4.71 \\
\hline Right Superior frontal gyrus, dorsolateral & 18009 & -25 & 52 & 34 & 4.68 \\
\hline Right Parahippocampal gyrus & 915 & -27 & 2 & -23 & 4.68 \\
\hline Right Postcentral gyrus & 22201 & -48 & -23 & 19 & 4.56 \\
\hline Right Inferior occipital gyrus & 8436 & -39 & -90 & -4 & 4.5 \\
\hline
\end{tabular}


bioRxiv preprint doi: https://doi.org/10.1101/306068; this version posted September 7, 2018. The copyright holder for this preprint (which was not certified by peer review) is the author/funder, who has granted bioRxiv a license to display the preprint in perpetuity. It is made available

\begin{tabular}{|c|c|c|c|c|c|}
\hline Right Temporal pole: superior temporal gyrus & 14405 & -27 & 3 & -23 & 4.4 \\
\hline Right Inferior frontal gyrus, orbital part & 4856 & -47 & 33 & -4 & 4.36 \\
\hline Right Fusiform gyrus & 9348 & -36 & -50 & -20 & 4.32 \\
\hline Right Middle frontal gyrus orbital part & 4671 & -29 & 54 & -17 & 4.29 \\
\hline Right Inferior parietal, but supramarginal and angular gyri & 5892 & -43 & -45 & 43 & 4.27 \\
\hline Right Inferior frontal gyrus, opercular part & 20620 & -43 & 11 & 26 & 4.25 \\
\hline Right Superior parietal gyrus & 25245 & -27 & -57 & 66 & 4.19 \\
\hline Right Cuneus & 38474 & -16 & -60 & 10 & 4.13 \\
\hline Right Angular gyrus & 5611 & -62 & -51 & 33 & 4.13 \\
\hline Right Inferior temporal gyrus & 36752 & -44 & -26 & -22 & 4.13 \\
\hline Right Gyrus Rectus & 15270 & -11 & 27 & -23 & 3.87 \\
\hline Right Precentral gyrus & 20242 & -47 & 10 & 21 & 3.84 \\
\hline Right Calcarine fissure and surrounding cortex & 9864 & -11 & -88 & -20 & 3.82 \\
\hline Right Temporal pole: middle temporal gyrus & 3374 & -53 & 9 & -39 & 3.8 \\
\hline
\end{tabular}

Supplementary Table 8. Left Striatum volume significant peaks of correlation with cortical thickness in AD.

\begin{tabular}{|l|l|l|l|l|l|}
\hline Brain Areas & vertex & $\mathbf{x}$ & $\mathbf{y}$ & $\mathbf{z}$ & $\mathbf{t}$ \\
\hline Left Temporal pole: middle temporal gyrus & 13483 & -47 & 18 & -35 & 4.85 \\
\hline Left Temporal pole: superior temporal gyrus & 13482 & -47 & 18 & -34 & 4.83 \\
\hline
\end{tabular}


bioRxiv preprint doi: https://doi.org/10.1101/306068; this version posted September 7, 2018. The copyright holder for this preprint (which was not certified by peer review) is the author/funder, who has granted bioRxiv a license to display the preprint in perpetuity. It is made available

\begin{tabular}{|c|c|c|c|c|c|}
\hline Left Middle temporal gyrus under & 13321 & -51 & 14 & -32 & 4.82 \\
\hline Left Inferior occipital gyrus & 33470 & -36 & -88 & -17 & 4.77 \\
\hline Left Olfactory Cortex & 16046 & -3 & 15 & -13 & 4.75 \\
\hline Left Precentral gyrus & 5246 & -54 & -5 & 30 & 4.53 \\
\hline Left Anterior cingulate and paracingulate gyri & 16057 & -2 & 17 & -11 & 4.47 \\
\hline Left Superior temporal gyrus & 13025 & -45 & 1 & -13 & 4.42 \\
\hline Left Postcentral gyrus & 5245 & -54 & -5 & 28 & 4.33 \\
\hline Left Gyrus Rectus & 15776 & -11 & 19 & -23 & 3.94 \\
\hline Left Rolandic operculum & 5063 & -54 & 9 & -1 & 3.91 \\
\hline Left Middle occipital gyrus & 33487 & -37 & -89 & -10 & 3.84 \\
\hline Left Inferior frontal gyrus, opercular part & 20117 & -51 & 10 & -2 & 3.81 \\
\hline Left Superior frontal gyrus, medial orbital & 15918 & -4 & 25 & -15 & 3.76 \\
\hline Left Fusiform gyrus & 35425 & -37 & -77 & -15 & 3.73 \\
\hline Left Supramarginal gyrus & 22112 & -59 & -20 & 27 & 3.7 \\
\hline Left Inferior frontal gyrus, triangular part & 11934 & -32 & 26 & 8 & 3.59 \\
\hline Left Superior frontal gyrus, dorsolateral & 26709 & -24 & 0 & 59 & 3.49 \\
\hline Left Heschl gyrus & 10647 & -41 & -32 & 14 & 3.45 \\
\hline Left Inferior temporal gyrus & 36527 & -45 & -6 & -47 & 3.41 \\
\hline Left Lingual gyrus & 35451 & -33 & -81 & -18 & 3.37 \\
\hline
\end{tabular}


bioRxiv preprint doi: https://doi.org/10.1101/306068; this version posted September 7, 2018. The copyright holder for this preprint (which was not certified by peer review) is the author/funder, who has granted bioRxiv a license to display the preprint in perpetuity. It is made available

\begin{tabular}{|c|c|c|c|c|c|}
\hline Left Insula $\quad$ under aCC-BY-NC & ense. & -42 & -3 & -12 & 3.34 \\
\hline Left Precuneus & 40677 & -13 & -53 & 3 & 3.33 \\
\hline Left Inferior parietal, but supramarginal and angular gyri & 21485 & -62 & -34 & 41 & 3.31 \\
\hline Left Angular gyrus & 23649 & -48 & -48 & 49 & 3.29 \\
\hline Left Cuneus & 38388 & -15 & -55 & 4 & 3.22 \\
\hline Left Middle frontal gyrus & 1213 & -40 & 49 & 8 & 3.15 \\
\hline Left Inferior frontal gyrus, orbital part & 18773 & -46 & 49 & -13 & 3.05 \\
\hline Left Calcarine fissure and surrounding cortex & 32853 & -2 & -85 & 17 & 3.02 \\
\hline Right Anterior cingulate and paracingulate gyri & 16540 & -1 & 38 & 12 & 5.06 \\
\hline Right Supramarginal gyrus & 5387 & -52 & -29 & 43 & 4.56 \\
\hline Right Superior temporal gyrus & 13011 & -45 & -1 & -11 & 4.52 \\
\hline Right Temporal pole: superior temporal gyrus & 13032 & -44 & 4 & -15 & 4.47 \\
\hline Right Temporal pole: middle temporal gyrus & 13635 & -43 & 8 & -42 & 4.42 \\
\hline Right Inferior parietal, but supramarginal and angular gyri & 22732 & -47 & -30 & 42 & 4.35 \\
\hline Right Inferior temporal gyrus & 13600 & -41 & 8 & -44 & 4.31 \\
\hline Right Middle temporal gyrus & 13438 & -55 & 4 & -35 & 4.19 \\
\hline Right Postcentral gyrus & 22857 & -42 & -30 & 41 & 4.01 \\
\hline Right Inferior frontal gyrus, triangular part & 19502 & -40 & 20 & 7 & 3.98 \\
\hline Right Rolandic operculum & 5488 & -37 & -23 & 18 & 3.96 \\
\hline
\end{tabular}


bioRxiv preprint doi: https://doi.org/10.1101/306068; this version posted September 7, 2018. The copyright holder for this preprint (which was not certified by peer review) is the author/funder, who has granted bioRxiv a license to display the preprint in perpetuity. It is made available

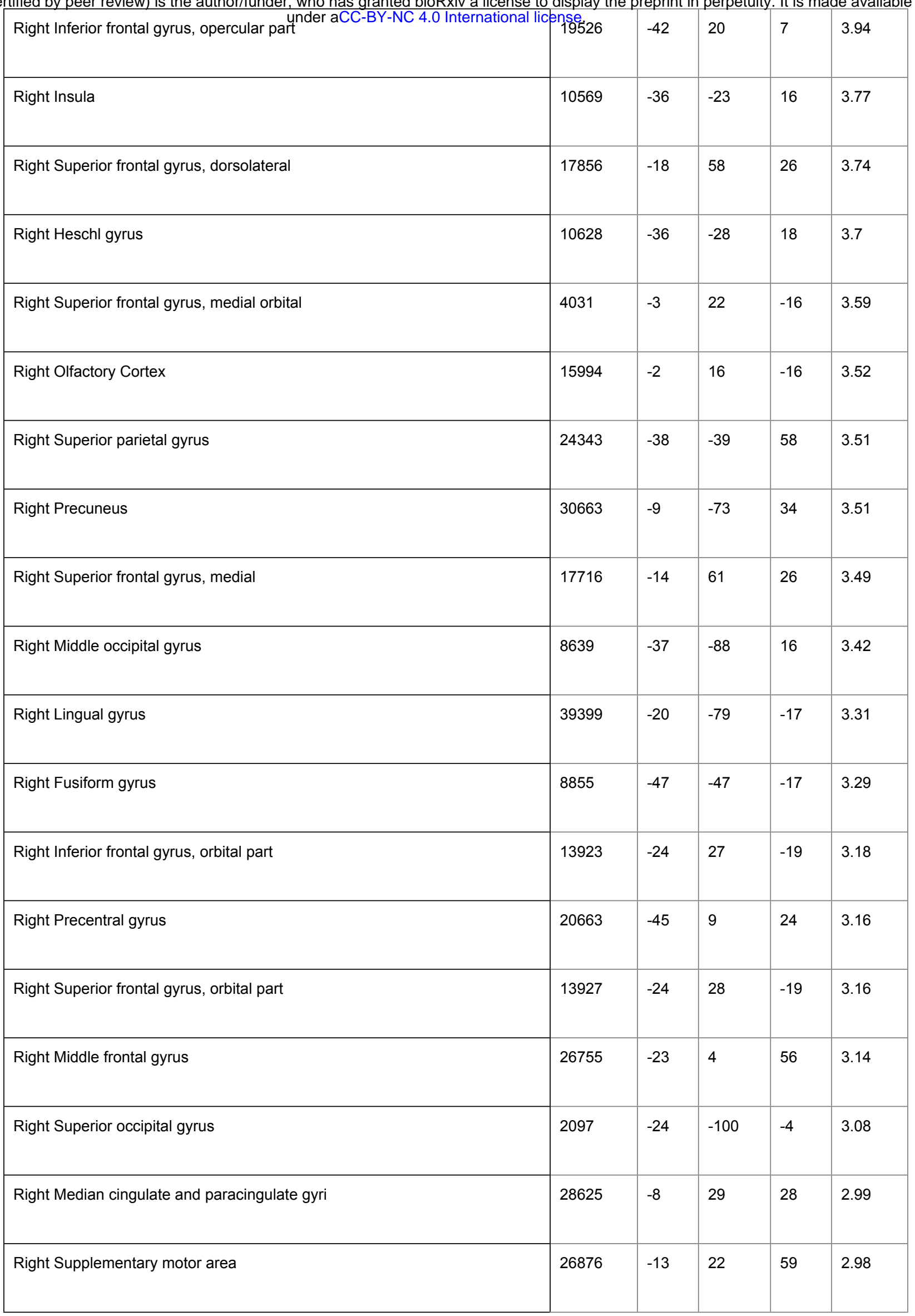


bioRxiv preprint doi: https://doi.org/10.1101/306068; this version posted September 7, 2018. The copyright holder for this preprint (which was not certified by peer review) is the author/funder, who has granted bioRxiv a license to display the preprint in perpetuity. It is made available

\begin{tabular}{|l|l|l|l|l|}
\hline Right Calcarine fissure and surrounding cortex & & & \\
\hline Right Cuneus & 30675 & -13 & -71 & 30 \\
\hline
\end{tabular}

\section{Supplementary Table 9. Right Striatum volume significant peaks of correlation} with cortical thickness in HC.

\begin{tabular}{|c|c|c|c|c|c|}
\hline Brain Areas & vertex & $\mathbf{x}$ & $\mathbf{y}$ & $\mathbf{z}$ & $\mathbf{t}$ \\
\hline Left Calcarine fissure and surrounding cortex & 33295 & -11 & -92 & -19 & 6.02 \\
\hline Left Precuneus & 30561 & -1 & -64 & 30 & 5.86 \\
\hline Left Superior frontal gyrus, medial orbital & 16899 & -5 & 56 & -14 & 5.85 \\
\hline Left Lingual gyrus & 39387 & -12 & -87 & -20 & 5.83 \\
\hline Left Median cingulate and paracingulate gyri & 30717 & -5 & -41 & 48 & 5.53 \\
\hline Left Inferior frontal gyrus, triangular part & 19949 & -43 & 30 & 21 & 5.45 \\
\hline Left Inferior frontal gyrus, opercular part & 20044 & -48 & 13 & 24 & 5.33 \\
\hline Left Middle frontal gyrus & 19179 & -40 & 32 & 19 & 5.29 \\
\hline Left Gyrus Rectus & 4261 & -4 & 56 & -15 & 5.2 \\
\hline Left Middle occipital gyrus & 8596 & -46 & -70 & 16 & 5.15 \\
\hline Left Fusiform gyrus & 9424 & -37 & -57 & -20 & 4.67 \\
\hline Left Inferior occipital gyrus & 35622 & -45 & -66 & -5 & 4.66 \\
\hline Left Supplementary motor area & 7023 & -6 & 5 & 46 & 4.63 \\
\hline Left Posterior cingulate gyrus & 30229 & -3 & -53 & 19 & 4.61 \\
\hline
\end{tabular}


bioRxiv preprint doi: https://doi.org/10.1101/306068; this version posted September 7, 2018. The copyright holder for this preprint (which was not certified by peer review) is the author/funder, who has granted bioRxiv a license to display the preprint in perpetuity. It is made available

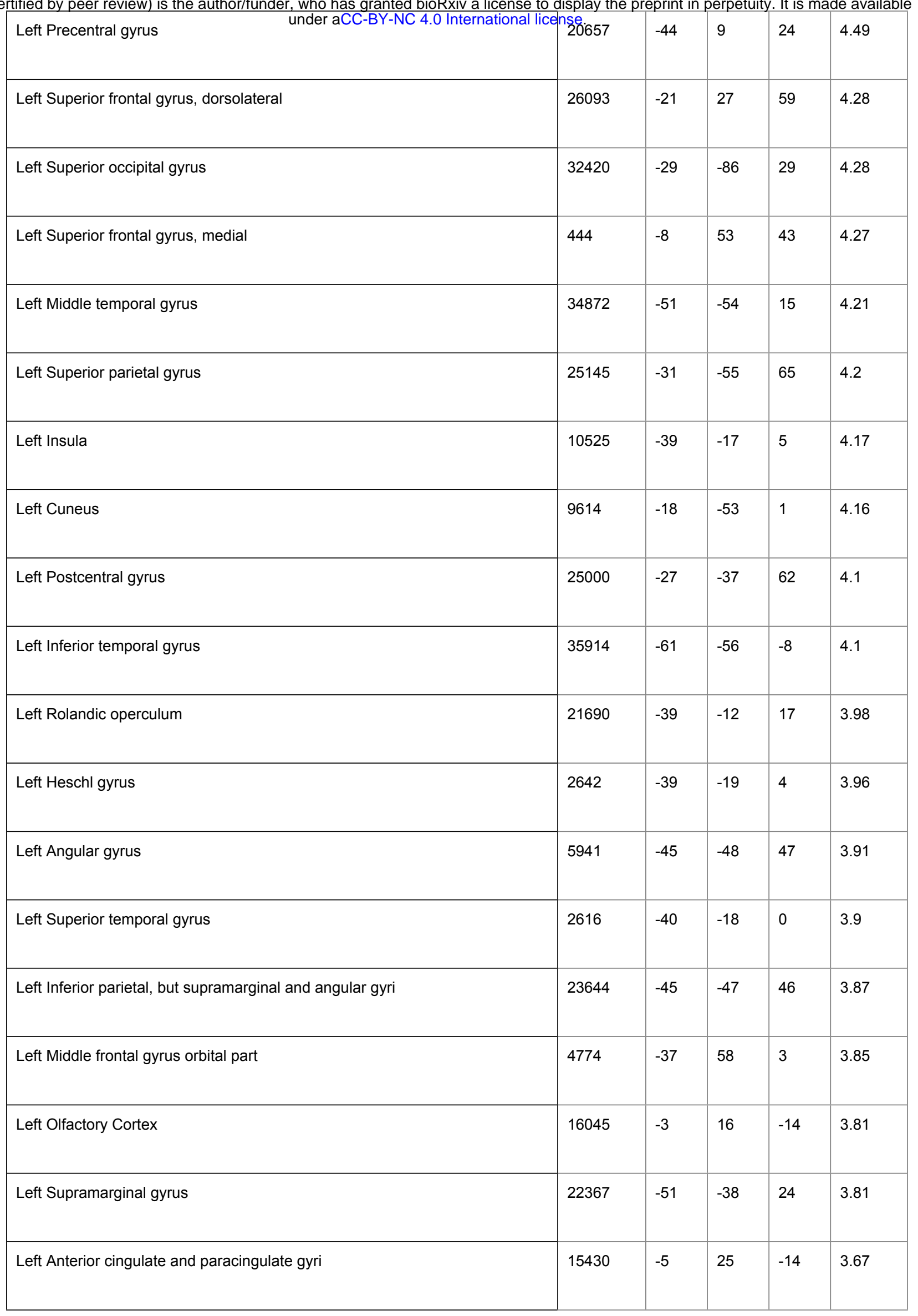


bioRxiv preprint doi: https://doi.org/10.1101/306068; this version posted September 7, 2018. The copyright holder for this preprint (which was not certified by peer review) is the author/funder, who has granted bioRxiv a license to display the preprint in perpetuity. It is made available

\begin{tabular}{|c|c|c|c|c|c|}
\hline Left Paracentral lobule $\quad$ under a & רड़. & -13 & -44 & 64 & 3.27 \\
\hline Left Supeiror frontal gyrus, orbital part & 15200 & -11 & 37 & -23 & 2.99 \\
\hline Left Temporal pole: superior temporal gyrus & 3307 & -44 & 18 & -19 & 2.73 \\
\hline Left Inferior frontal gyrus, orbital part & 4808 & -42 & 46 & -2 & 2.68 \\
\hline Left Parahippocampal gyrus & 3614 & -27 & 0 & -23 & 2.61 \\
\hline Left Temporal pole: middle temporal gyrus & 3340 & -48 & 12 & -30 & 2.47 \\
\hline Right Median cingulate and paracingulate gyri & 29254 & -11 & -15 & 44 & 6.22 \\
\hline Right Supplementary motor area & 27989 & -8 & 2 & 46 & 5.85 \\
\hline Right Superior temporal gyrus & 10884 & -59 & -8 & -7 & 5.74 \\
\hline Right Posterior cingulate gyrus & 7574 & -4 & -48 & 35 & 5.73 \\
\hline Right Middle frontal gyrus & 1166 & -33 & 44 & 28 & 5.65 \\
\hline Right Middle occipital gyrus & 34407 & -43 & -83 & 13 & 5.56 \\
\hline Right Inferior frontal gyrus, triangular part & 19399 & -54 & 32 & 9 & 5.55 \\
\hline Right Paracentral lobule & 29429 & -8 & -25 & 46 & 5.49 \\
\hline Right Anterior cingulate and paracingulate gyri & 28019 & -4 & 48 & 27 & 5.35 \\
\hline Right Precuneus & 40664 & -6 & -48 & 2 & 5.34 \\
\hline Right Superior frontal gyrus, medial & 27624 & -4 & 50 & 28 & 5.26 \\
\hline Right Supramarginal gyrus & 22224 & -45 & -29 & 16 & 5.25 \\
\hline Right Olfactory Cortex & 16042 & -3 & 15 & -15 & 5.16 \\
\hline
\end{tabular}


bioRxiv preprint doi: https://doi.org/10.1101/306068; this version posted September 7, 2018. The copyright holder for this preprint (which was not certified by peer review) is the author/funder, who has granted bioRxiv a license to display the preprint in perpetuity. It is made available

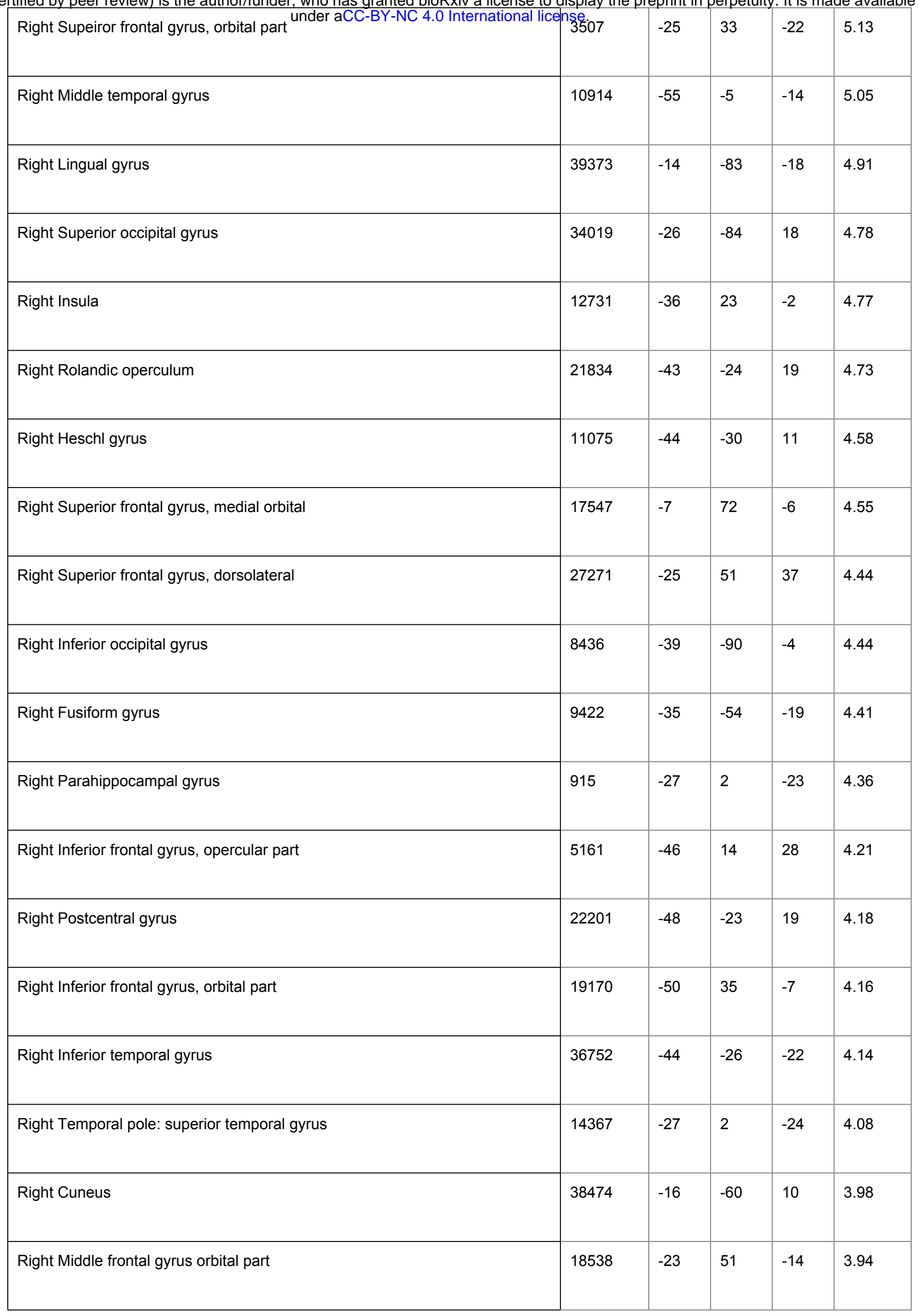


bioRxiv preprint doi: https://doi.org/10.1101/306068; this version posted September 7, 2018. The copyright holder for this preprint (which was not certified by peer review) is the author/funder, who has granted bioRxiv a license to display the preprint in perpetuity. It is made available

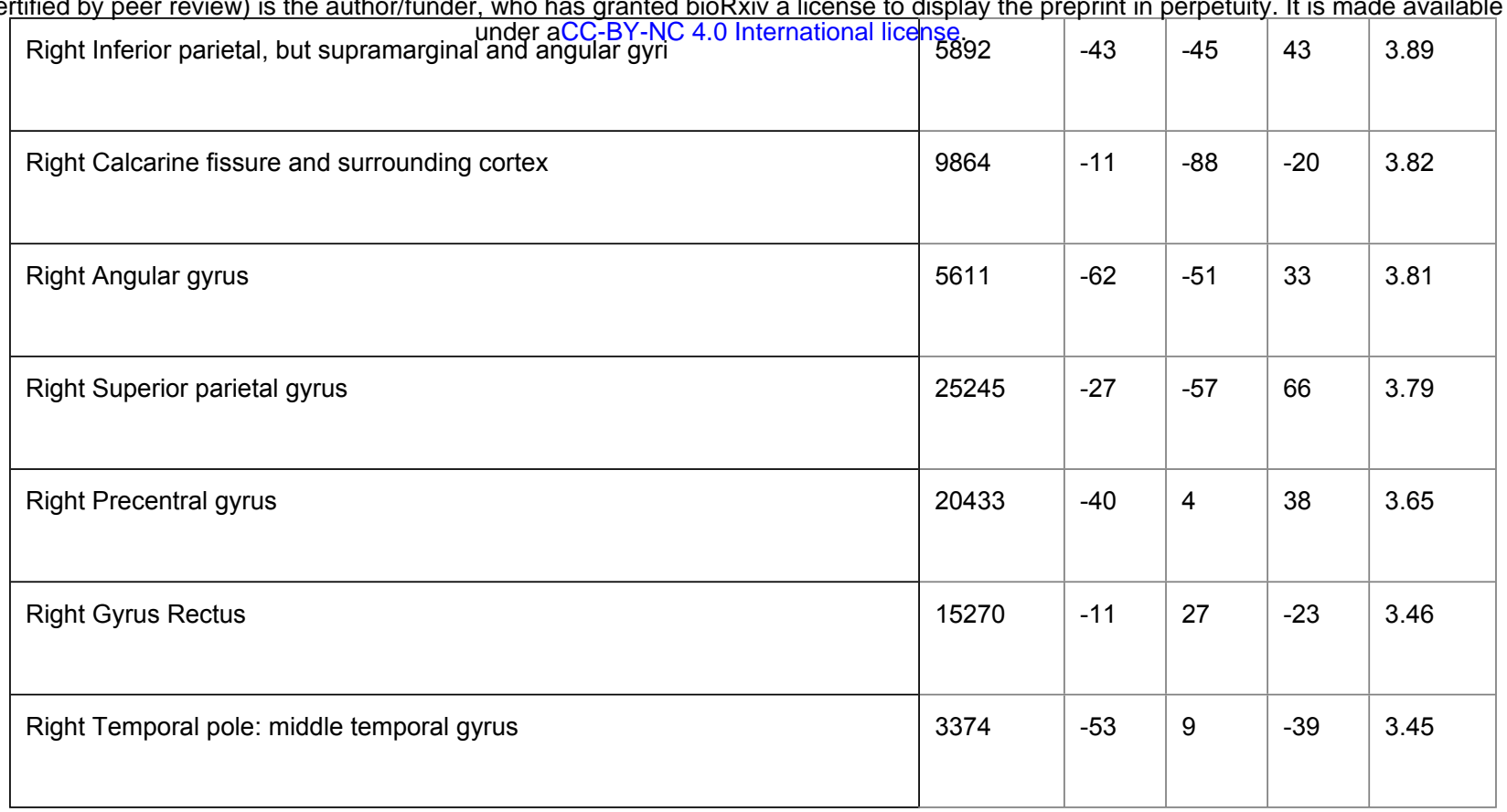

Supplementary Table 10. Right Striatum volume significant peaks of correlation with cortical thickness in AD.

\begin{tabular}{|c|c|c|c|c|c|}
\hline Brain Areas & vertex & $\mathbf{x}$ & $\mathbf{y}$ & $\mathbf{z}$ & $\mathbf{t}$ \\
\hline Left Olfactory Cortex & 16045 & -3 & 16 & -14 & 4.72 \\
\hline Left Temporal pole: superior temporal gyrus & 13190 & -48 & 18 & -33 & 4.69 \\
\hline Left Temporal pole: middle temporal gyrus & 13483 & -47 & 18 & -35 & 4.63 \\
\hline Left Middle temporal gyrus & 13321 & -51 & 14 & -32 & 4.58 \\
\hline Left Superior temporal gyrus & 3199 & -44 & 0 & -14 & 4.57 \\
\hline Left Inferior occipital gyrus & 33470 & -36 & -88 & -17 & 4.42 \\
\hline Left Anterior cingulate and paracingulate gyri & 16057 & -2 & 17 & -11 & 4.25 \\
\hline Left Precentral gyrus & 20860 & -55 & -4 & 30 & 4.2 \\
\hline Left Gyrus Rectus & 15776 & -11 & 19 & -23 & 4.08 \\
\hline
\end{tabular}


bioRxiv preprint doi: https://doi.org/10.1101/306068; this version posted September 7, 2018. The copyright holder for this preprint (which was not certified by peer review) is the author/funder, who has granted bioRxiv a license to display the preprint in perpetuity. It is made available

\begin{tabular}{|c|c|c|c|c|c|}
\hline Left Postcentral gyrus $\quad$ under aCC-BY-NC & רse. & -54 & -5 & 28 & 4.03 \\
\hline Left Superior frontal gyrus, medial orbital & 1018 & -3 & 24 & -16 & 3.81 \\
\hline Left Inferior frontal gyrus, triangular part & 11946 & -31 & 26 & 8 & 3.69 \\
\hline Left Supramarginal gyrus & 21935 & -62 & -35 & 34 & 3.66 \\
\hline Left Fusiform gyrus & 35425 & -37 & -77 & -15 & 3.52 \\
\hline Left Insula & 3193 & -42 & -3 & -12 & 3.51 \\
\hline Left Middle occipital gyrus & 33487 & -37 & -89 & -10 & 3.48 \\
\hline Left Rolandic operculum & 5063 & -54 & 9 & -1 & 3.45 \\
\hline Left Inferior frontal gyrus, opercular part & 20117 & -51 & 10 & -2 & 3.35 \\
\hline Left Inferior parietal, but supramarginal and angular gyri & 21485 & -62 & -34 & 41 & 3.33 \\
\hline Right Anterior cingulate and paracingulate gyri & 16540 & -1 & 38 & 12 & 5.24 \\
\hline Right Supramarginal gyrus & 5387 & -52 & -29 & 43 & 4.55 \\
\hline Right Superior temporal gyrus & 12707 & -44 & 1 & -14 & 4.45 \\
\hline Right Temporal pole: superior temporal gyrus & 13034 & -44 & 4 & -16 & 4.38 \\
\hline Right Inferior parietal, but supramarginal and angular gyri & 22732 & -47 & -30 & 42 & 4.3 \\
\hline Right Temporal pole: middle temporal gyrus & 3429 & -42 & 9 & -41 & 4.28 \\
\hline Right Inferior temporal gyrus & 13600 & -41 & 8 & -44 & 4.19 \\
\hline Right Middle temporal gyrus & 13438 & -55 & 4 & -35 & 4.14 \\
\hline Right Inferior frontal gyrus, triangular part & 19502 & -40 & 20 & 7 & 3.96 \\
\hline
\end{tabular}


bioRxiv preprint doi: https://doi.org/10.1101/306068; this version posted September 7, 2018. The copyright holder for this preprint (which was not certified by peer review) is the author/funder, who has granted bioRxiv a license to display the preprint in perpetuity. It is made available

\begin{tabular}{|c|c|c|c|c|c|}
\hline Right Postcentral gyrus unc & 1s. & -51 & -26 & 38 & 3.96 \\
\hline Right Rolandic operculum & 21847 & -39 & -21 & 17 & 3.93 \\
\hline Right Inferior frontal gyrus, opercular part & 19526 & -42 & 20 & 7 & 3.89 \\
\hline Right Superior frontal gyrus, dorsolateral & 17856 & -18 & 58 & 26 & 3.78 \\
\hline Right Heschl gyrus & 10628 & -36 & -28 & 18 & 3.68 \\
\hline Right Olfactory Cortex & 15994 & -2 & 16 & -16 & 3.64 \\
\hline Right Insula & 10569 & -36 & -23 & 16 & 3.61 \\
\hline Right Middle occipital gyrus & 8639 & -37 & -88 & 16 & 3.59 \\
\hline Right Superior parietal gyrus & 24343 & -38 & -39 & 58 & 3.54 \\
\hline Right Superior frontal gyrus, medial orbital & 4031 & -3 & 22 & -16 & 3.48 \\
\hline Right Precuneus & 7939 & -11 & -76 & 49 & 3.46 \\
\hline Right Superior frontal gyrus, medial & 4460 & -16 & 59 & 26 & 3.42 \\
\hline Right Precentral gyrus & 20661 & -46 & 9 & 25 & 3.38 \\
\hline Right Inferior frontal gyrus, orbital part & 13923 & -24 & 27 & -19 & 3.26 \\
\hline Right Lingual gyrus & 39399 & -20 & -79 & -17 & 3.24 \\
\hline Right Superior frontal gyrus, orbital part & 13927 & -24 & 28 & -19 & 3.23 \\
\hline Right Fusiform gyrus & 13717 & -28 & 2 & -43 & 3.21 \\
\hline Right Middle frontal gyrus & 26755 & -23 & 4 & 56 & 3.15 \\
\hline
\end{tabular}

Supplementary Table 11. Left nucleus accumbens volume significant peaks of correlation with cortical thickness for ALL participants. 
bioRxiv preprint doi: https://doi.org/10.1101/306068; this version posted September 7, 2018. The copyright holder for this preprint (which was not certified by peer review) is the author/funder, who has granted bioRxiv a license to display the preprint in perpetuity. It is made available under aCC-BY-NC 4.0 International license.

\begin{tabular}{|c|c|c|c|c|c|}
\hline Brain Areas & vertex & $\mathbf{x}$ & $\mathbf{y}$ & $\mathbf{z}$ & $\mathbf{t}$ \\
\hline Left Calcarine fissure and surrounding cortex & 33204 & -10 & -92 & -19 & 5.92 \\
\hline Left Lingual gyrus & 39386 & -10 & -86 & -19 & 5.25 \\
\hline Left Olfactory Cortex & 16046 & -3 & 15 & -13 & 5.09 \\
\hline Left Anterior cingulate and paracingulate gyri & 16057 & -2 & 17 & -11 & 4.84 \\
\hline Left Cuneus & 38621 & -15 & -64 & 7 & 4.64 \\
\hline Left Gyrus Rectus & 16944 & -2 & 60 & -18 & 4.6 \\
\hline Left Superior frontal gyrus, medial orbital & 16951 & -2 & 60 & -14 & 4.39 \\
\hline Left Superior parietal gyrus & 6284 & -27 & -37 & 61 & 4.17 \\
\hline Left Superior temporal gyrus & 22384 & -45 & -34 & 17 & 4.15 \\
\hline Left Postcentral gyrus & 24999 & -28 & -37 & 62 & 4.12 \\
\hline Left Middle frontal gyrus & 25975 & -23 & 26 & 41 & 4.08 \\
\hline Left Superior frontal gyrus, dorsolateral & 25993 & -22 & 27 & 41 & 3.96 \\
\hline Left Inferior frontal gyrus, opercular part & 4909 & -38 & 17 & 5 & 3.95 \\
\hline Left Middle temporal gyrus & 13324 & -52 & 10 & -28 & 3.89 \\
\hline Left Rolandic operculum & 328 & -48 & 5 & 1 & 3.88 \\
\hline Left Inferior frontal gyrus, triangular part & 19219 & -50 & 33 & 13 & 3.87 \\
\hline Left Heschl gyrus & 11076 & -45 & -29 & 11 & 3.82 \\
\hline
\end{tabular}


bioRxiv preprint doi: https://doi.org/10.1101/306068; this version posted September 7, 2018. The copyright holder for this preprint (which was not certified by peer review) is the author/funder, who has granted bioRxiv a license to display the preprint in perpetuity. It is made available

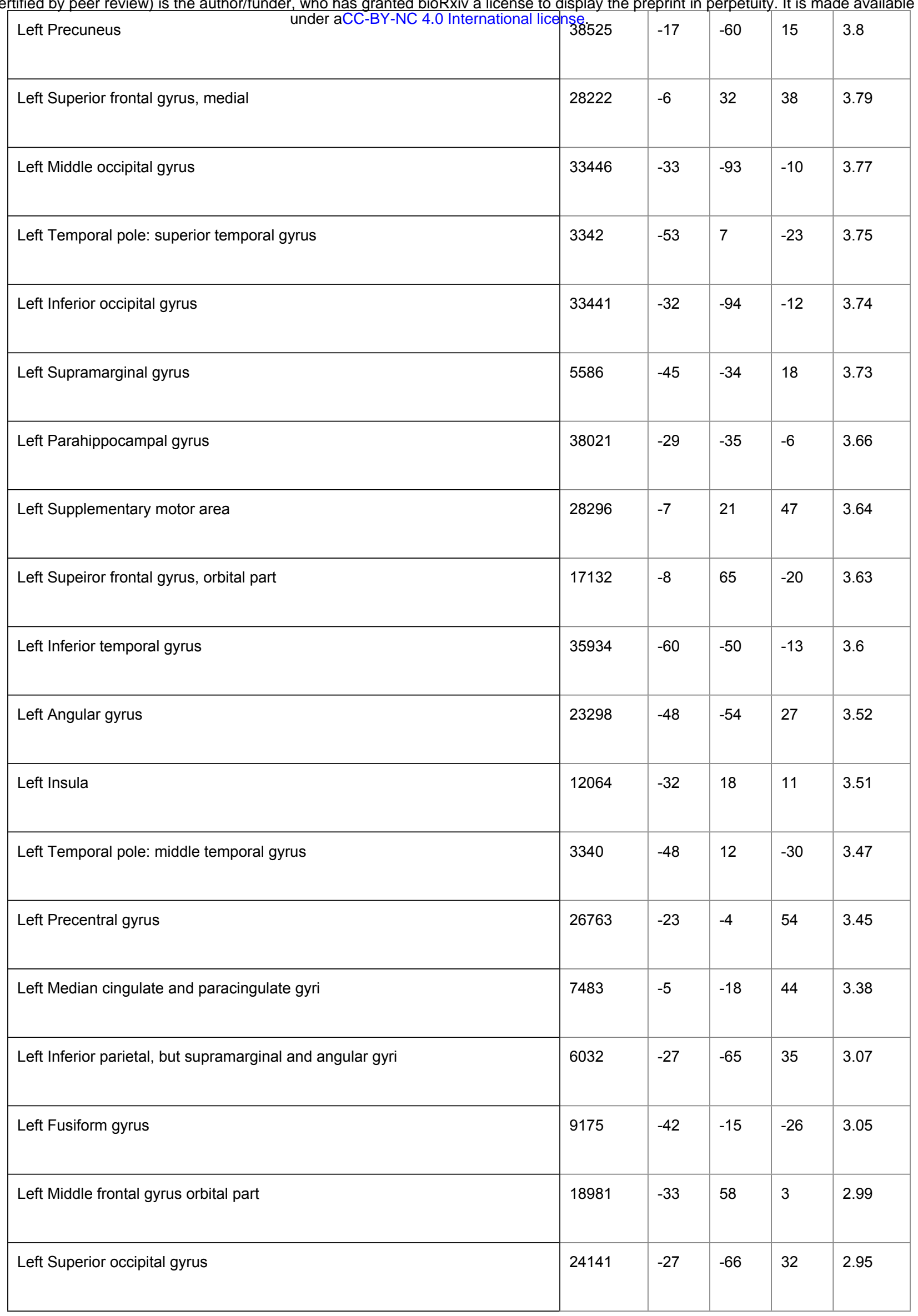


bioRxiv preprint doi: https://doi.org/10.1101/306068; this version posted September 7, 2018. The copyright holder for this preprint (which was not certified by peer review) is the author/funder, who has granted bioRxiv a license to display the preprint in perpetuity. It is made available

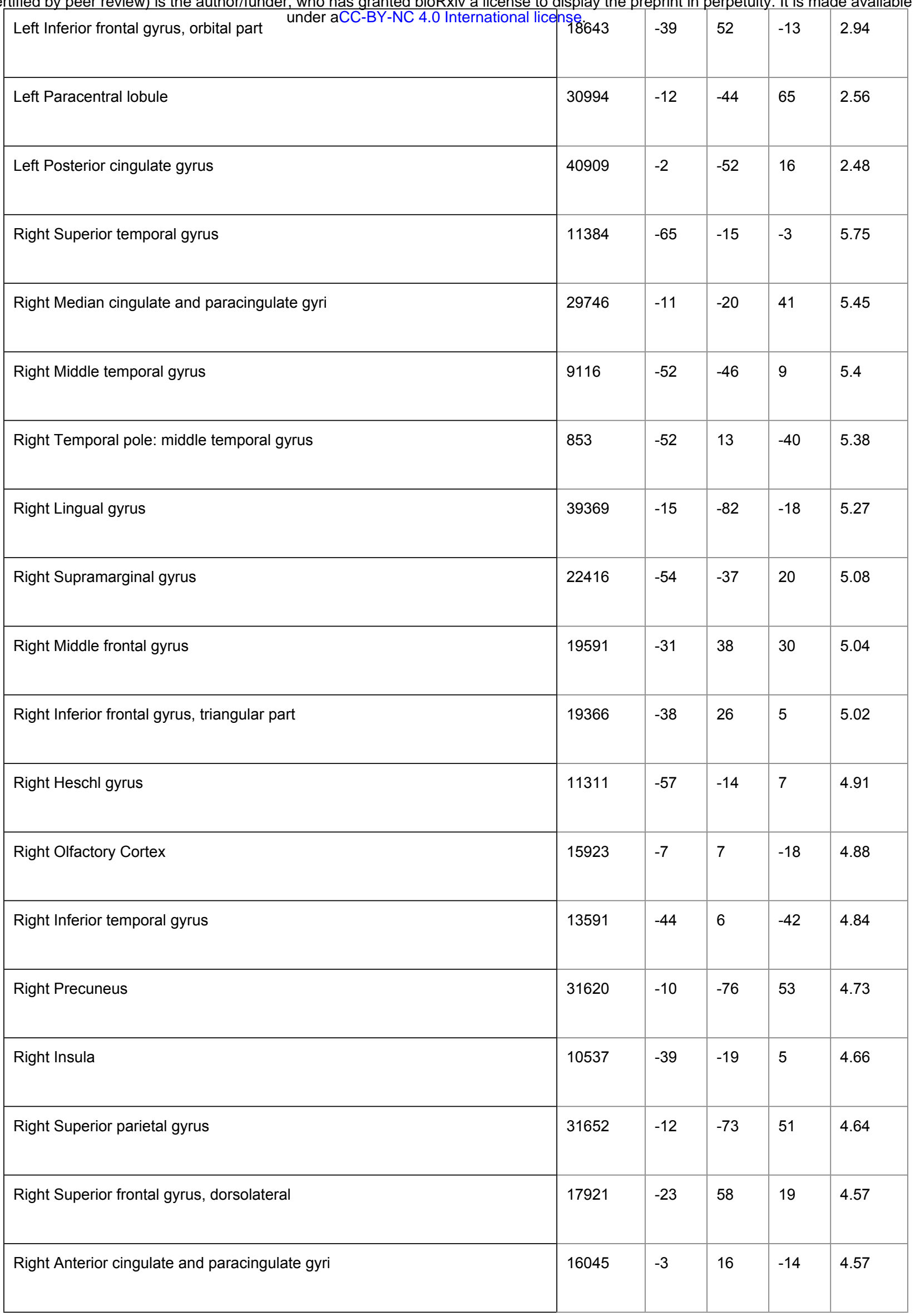


bioRxiv preprint doi: https://doi.org/10.1101/306068; this version posted September 7, 2018. The copyright holder for this preprint (which was not certified by peer review) is the author/funder, who has granted bioRxiv a license to display the preprint in perpetuity. It is made available

\begin{tabular}{|c|c|c|c|c|c|}
\hline Right Angular gyrus $\quad$ under aCC-BY-NC & רse. & -28 & -67 & 33 & 4.52 \\
\hline Right Inferior parietal, but supramarginal and angular gyri & 390 & -27 & -65 & 33 & 4.45 \\
\hline Right Calcarine fissure and surrounding cortex & 39283 & -9 & -83 & -15 & 4.42 \\
\hline Right Cuneus & 31925 & -16 & -65 & 19 & 4.41 \\
\hline Right Middle occipital gyrus & 24060 & -28 & -67 & 32 & 4.41 \\
\hline Right Postcentral gyrus & 6134 & -41 & -34 & 58 & 4.31 \\
\hline Right Posterior cingulate gyrus & 29964 & 0 & -33 & 33 & 4.17 \\
\hline Right Temporal pole: superior temporal gyrus & 13495 & -46 & 21 & -35 & 4.1 \\
\hline Right Superior occipital gyrus & 34019 & -26 & -84 & 18 & 4.02 \\
\hline Right Inferior frontal gyrus, opercular part & 4908 & -41 & 20 & 7 & 3.95 \\
\hline Right Superior frontal gyrus, medial & 4440 & -4 & 52 & 25 & 3.94 \\
\hline Right Fusiform gyrus & 37897 & -25 & -76 & -13 & 3.85 \\
\hline Right Supplementary motor area & 7386 & -7 & -21 & 45 & 3.81 \\
\hline Right Paracentral lobule & 29424 & -8 & -24 & 46 & 3.79 \\
\hline Right Precentral gyrus & 21025 & -39 & -18 & 43 & 3.77 \\
\hline Right Rolandic operculum & 5489 & -41 & -24 & 19 & 3.76 \\
\hline Right Inferior frontal gyrus, orbital part & 19169 & -51 & 38 & -7 & 3.62 \\
\hline Right Gyrus Rectus & 15273 & -12 & 25 & -22 & 3.56 \\
\hline Right Supeiror frontal gyrus, orbital part & 15242 & -12 & 26 & -24 & 3.49 \\
\hline
\end{tabular}


bioRxiv preprint doi: https://doi.org/10.1101/306068; this version posted September 7, 2018. The copyright holder for this preprint (which was not certified by peer review) is the author/funder, who has granted bioRxiv a license to display the preprint in perpetuity. It is made available

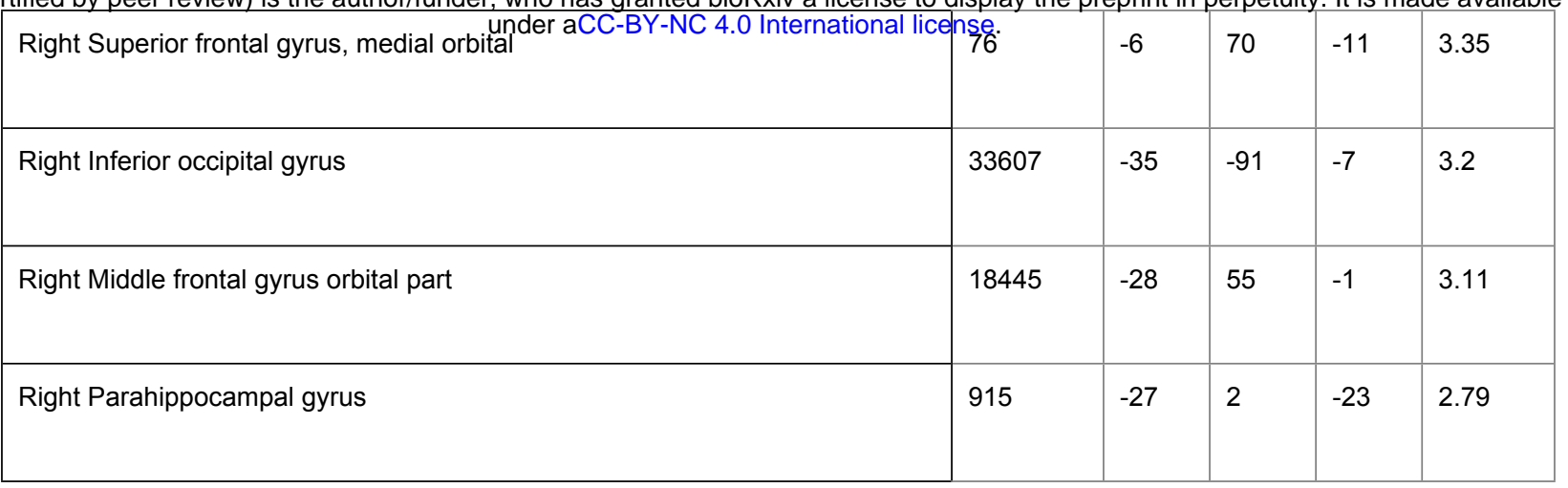

Supplementary Table 12. Left nucleus accumbens volume significant peaks of correlation with cortical thickness for HC.

\begin{tabular}{|c|c|c|c|c|c|}
\hline Brain Areas & vertex & $\mathbf{x}$ & $y$ & $\mathbf{z}$ & $\mathbf{t}$ \\
\hline Left Calcarine fissure and surrounding cortex & 33297 & -12 & -94 & -18 & 6.27 \\
\hline Left Superior frontal gyrus, medial orbital & 4262 & -4 & 58 & -14 & 5.53 \\
\hline Left Gyrus Rectus & 16932 & -3 & 58 & -15 & 5.33 \\
\hline Left Lingual gyrus & 39387 & -12 & -87 & -20 & 4.64 \\
\hline Left Inferior frontal gyrus, triangular part & 19189 & -44 & 34 & 16 & 4.34 \\
\hline Left Middle frontal gyrus & 20442 & -48 & 24 & 33 & 4.07 \\
\hline Left Middle occipital gyrus & 34523 & -45 & -75 & 28 & 4.03 \\
\hline Left Superior frontal gyrus, medial & 28109 & -4 & 36 & 33 & 4.01 \\
\hline Left Olfactory Cortex & 16045 & -3 & 16 & -14 & 3.88 \\
\hline Left Supplementary motor area & 7102 & -6 & 22 & 47 & 3.87 \\
\hline Left Superior frontal gyrus, dorsolateral & 1658 & -21 & 29 & 59 & 3.8 \\
\hline Left Postcentral gyrus & 24470 & -30 & -37 & 61 & 3.69 \\
\hline
\end{tabular}


bioRxiv preprint doi: https://doi.org/10.1101/306068; this version posted September 7, 2018. The copyright holder for this preprint (which was not certified by peer review) is the author/funder, who has granted bioRxiv a license to display the preprint in perpetuity. It is made available

\begin{tabular}{|c|c|c|c|c|c|}
\hline Left Median cingulate and paracingulate gyri & רse. 29550 & -5 & -40 & 48 & 3.67 \\
\hline Left Supeiror frontal gyrus, orbital part & 17132 & -8 & 65 & -20 & 3.65 \\
\hline Left Precuneus & 9613 & -16 & -51 & 0 & 3.62 \\
\hline Left Superior parietal gyrus & 104 & -29 & -37 & 60 & 3.6 \\
\hline Left Middle temporal gyrus & 8695 & -43 & -66 & 21 & 3.53 \\
\hline Left Cuneus & 38543 & -17 & -62 & 16 & 3.41 \\
\hline Left Angular gyrus & 34660 & -43 & -67 & 23 & 3.4 \\
\hline Left Superior temporal gyrus & 13304 & -53 & 4 & -20 & 3.23 \\
\hline Left Anterior cingulate and paracingulate gyri & 16052 & -2 & 19 & -12 & 3.17 \\
\hline Left Inferior frontal gyrus, opercular part & 2565 & -39 & 7 & 7 & 3.14 \\
\hline Left Inferior occipital gyrus & 35577 & -48 & -72 & -10 & 3.07 \\
\hline Left Rolandic operculum & 5438 & -48 & 0 & 9 & 3.05 \\
\hline Left Parahippocampal gyrus & 38021 & -29 & -35 & -6 & 2.96 \\
\hline Left Inferior temporal gyrus & 9020 & -55 & -61 & -10 & 2.95 \\
\hline Left Middle frontal gyrus orbital part & 18979 & -40 & 55 & 2 & 2.94 \\
\hline Right Middle frontal gyrus & 18330 & -34 & 42 & 29 & 5.77 \\
\hline Right Median cingulate and paracingulate gyri & 29455 & -12 & -23 & 41 & 5.71 \\
\hline Right Superior temporal gyrus & 11154 & -61 & -21 & 12 & 5.54 \\
\hline Right Inferior frontal gyrus, triangular part & 1223 & -53 & 33 & 10 & 5.43 \\
\hline
\end{tabular}


bioRxiv preprint doi: https://doi.org/10.1101/306068; this version posted September 7, 2018. The copyright holder for this preprint (which was not certified by peer review) is the author/funder, who has granted bioRxiv a license to display the preprint in perpetuity. It is made available

\begin{tabular}{|c|c|c|c|c|c|}
\hline Right Heschl gyrus under & 718 & -60 & -12 & 6 & 5.1 \\
\hline Right Supeiror frontal gyrus, orbital part & 4286 & -22 & 51 & -15 & 4.95 \\
\hline Right Olfactory Cortex & 16042 & -3 & 15 & -15 & 4.79 \\
\hline Right Anterior cingulate and paracingulate gyri & 16046 & -3 & 15 & -13 & 4.74 \\
\hline Right Superior frontal gyrus, dorsolateral & 27302 & -22 & 50 & 38 & 4.68 \\
\hline Right Paracentral lobule & 29429 & -8 & -25 & 46 & 4.59 \\
\hline Right Middle frontal gyrus orbital part & 17061 & -22 & 54 & -15 & 4.57 \\
\hline Right Lingual gyrus & 39373 & -14 & -83 & -18 & 4.55 \\
\hline Right Insula & 10376 & -42 & -12 & -1 & 4.54 \\
\hline Right Supramarginal gyrus & 5647 & -61 & -43 & 27 & 4.51 \\
\hline Right Supplementary motor area & 7386 & -7 & -21 & 45 & 4.43 \\
\hline Right Precuneus & 31861 & -16 & -62 & 20 & 4.39 \\
\hline Right Posterior cingulate gyrus & 30048 & -8 & -40 & 38 & 4.32 \\
\hline Right Middle temporal gyrus & 10776 & -55 & 0 & -18 & 4.3 \\
\hline Right Fusiform gyrus & 2371 & -31 & -58 & -19 & 4.19 \\
\hline Right Middle occipital gyrus & 34505 & -45 & -83 & 23 & 4 \\
\hline Right Inferior occipital gyrus & 33618 & -39 & -89 & -4 & 3.99 \\
\hline Right Inferior frontal gyrus, orbital part & 18796 & -51 & 40 & -12 & 3.96 \\
\hline Right Superior frontal gyrus, medial orbital & 17592 & -14 & 71 & -6 & 3.94 \\
\hline
\end{tabular}


bioRxiv preprint doi: https://doi.org/10.1101/306068; this version posted September 7, 2018. The copyright holder for this preprint (which was not certified by peer review) is the author/funder, who has granted bioRxiv a license to display the preprint in perpetuity. It is made available

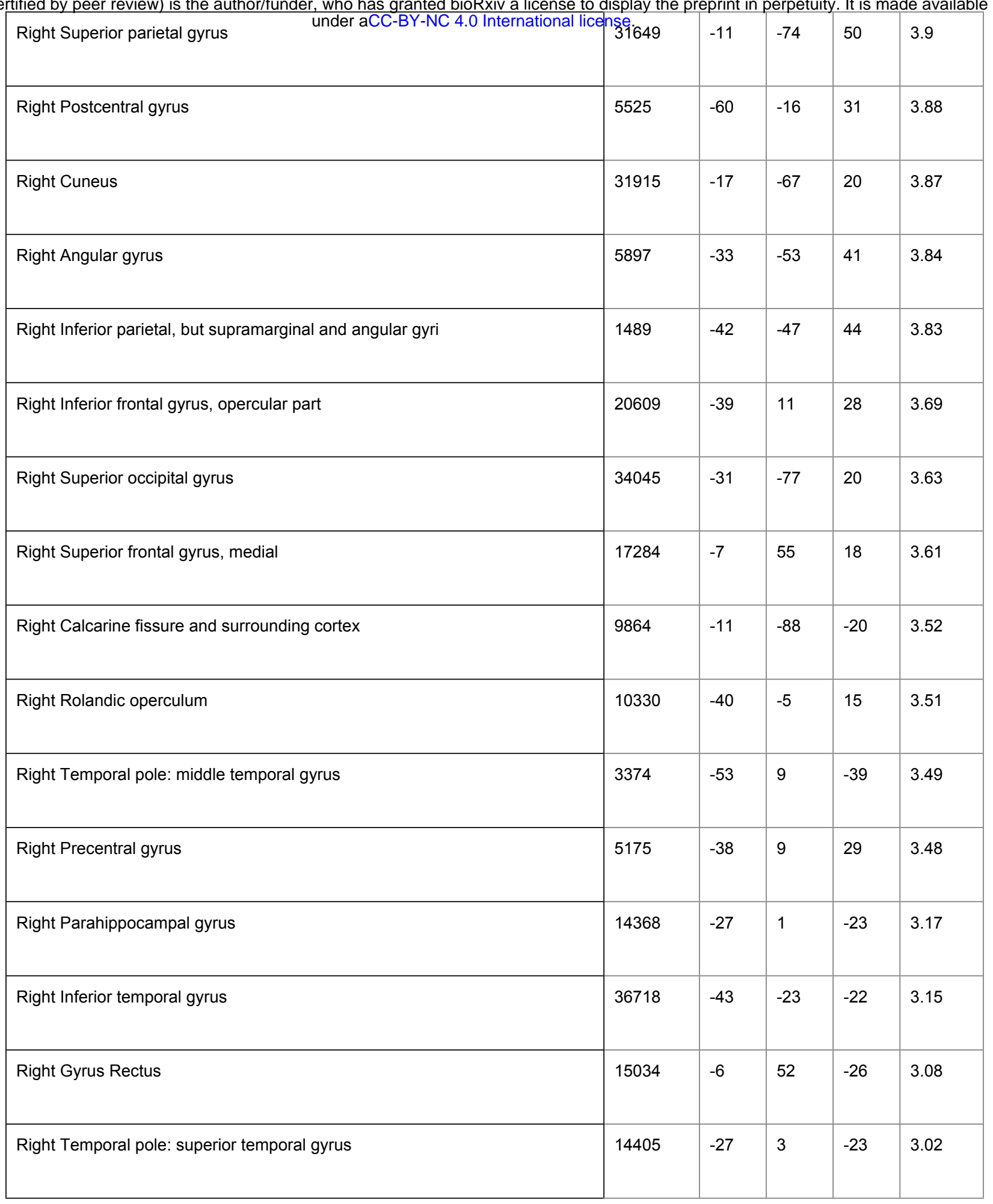

Supplementary Table 13. Right precommisural putamen volume significant peaks of correlation with cortical thickness for ALL participants. 
bioRxiv preprint doi: https://doi.org/10.1101/306068; this version posted September 7, 2018. The copyright holder for this preprint (which was not certified by peer review) is the author/funder, who has granted bioRxiv a license to display the preprint in perpetuity. It is made available

\begin{tabular}{|c|c|c|c|c|c|}
\hline Left Precuneus $\quad$ under & 'șe. & -3 & -69 & 45 & 4.94 \\
\hline Left Middle frontal gyrus & 18965 & -32 & 56 & 7 & 4.74 \\
\hline Left Lingual gyrus & 2475 & -13 & -86 & -19 & 4.43 \\
\hline Left Insula & 2639 & -40 & -16 & 4 & 4.36 \\
\hline Left Middle frontal gyrus orbital part & 18981 & -33 & 58 & 3 & 4.35 \\
\hline Left Calcarine fissure and surrounding cortex & 39420 & -13 & -89 & -20 & 4.34 \\
\hline Left Middle temporal gyrus & 13331 & -53 & 12 & -30 & 4.25 \\
\hline Left Inferior occipital gyrus & 33458 & -32 & -94 & -14 & 4.21 \\
\hline Left Temporal pole: superior temporal gyrus & 13188 & -49 & 16 & -30 & 4.2 \\
\hline Left Temporal pole: middle temporal gyrus & 13285 & -48 & 13 & -30 & 4.09 \\
\hline Left Inferior temporal gyrus & 35837 & -50 & -50 & -20 & 4.08 \\
\hline Left Heschl gyrus & 2642 & -39 & -19 & 4 & 3.98 \\
\hline Left Superior temporal gyrus & 22418 & -53 & -36 & 19 & 3.9 \\
\hline Left Olfactory Cortex & 15928 & -5 & 9 & -18 & 3.88 \\
\hline Left Precentral gyrus & 20887 & -53 & -5 & 30 & 3.78 \\
\hline Left Superior frontal gyrus, dorsolateral & 6554 & -23 & 24 & 57 & 3.73 \\
\hline Left Fusiform gyrus & 37217 & -46 & -42 & -21 & 3.73 \\
\hline Left Inferior frontal gyrus, triangular part & 19050 & -40 & 45 & 7 & 3.7 \\
\hline Left Median cingulate and paracingulate gyri & 29797 & -1 & -22 & 42 & 3.7 \\
\hline
\end{tabular}


bioRxiv preprint doi: https://doi.org/10.1101/306068; this version posted September 7, 2018. The copyright holder for this preprint (which was not certified by peer review) is the author/funder, who has granted bioRxiv a license to display the preprint in perpetuity. It is made available

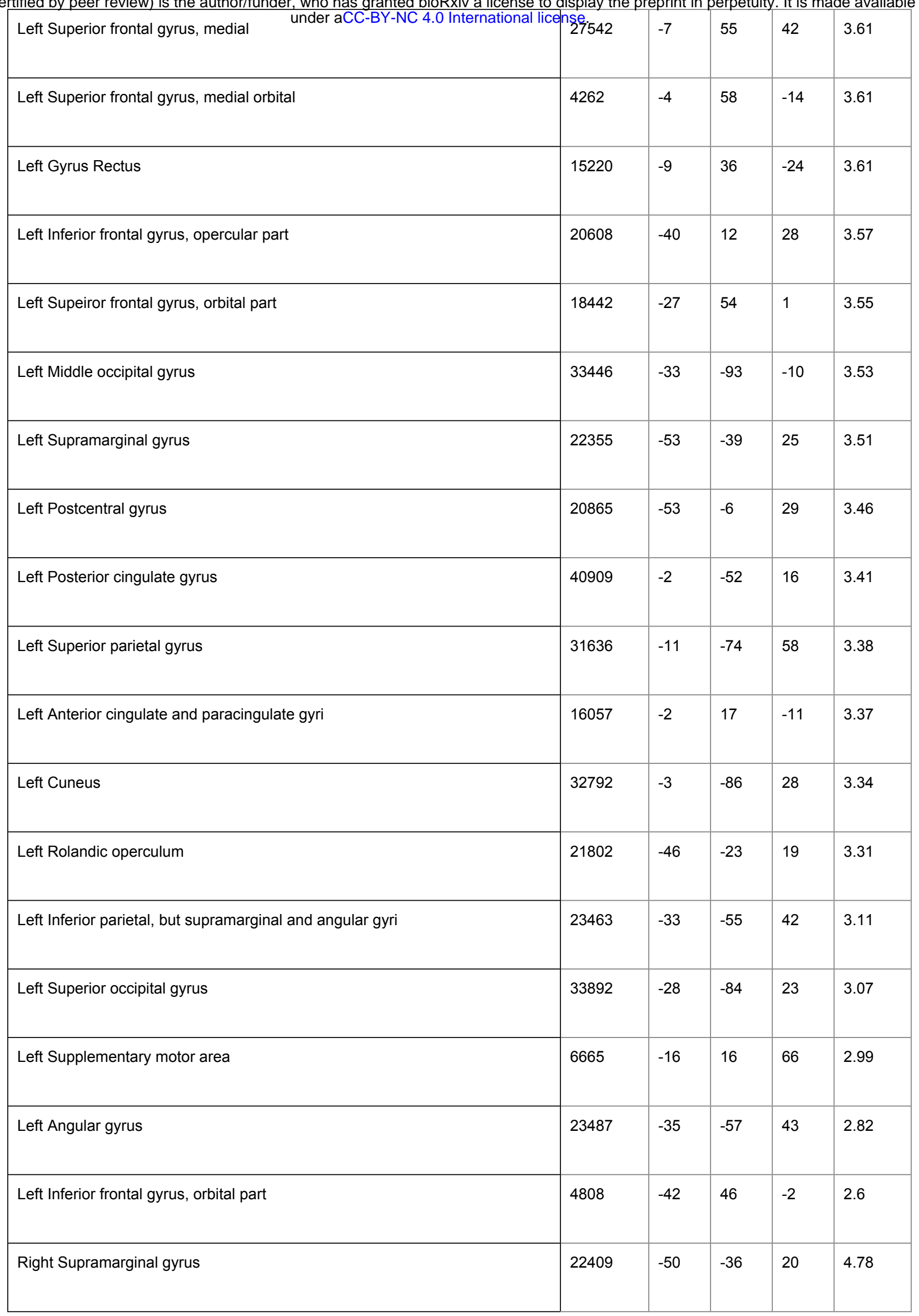


bioRxiv preprint doi: https://doi.org/10.1101/306068; this version posted September 7, 2018. The copyright holder for this preprint (which was not certified by peer review) is the author/funder, who has granted bioRxiv a license to display the preprint in perpetuity. It is made available

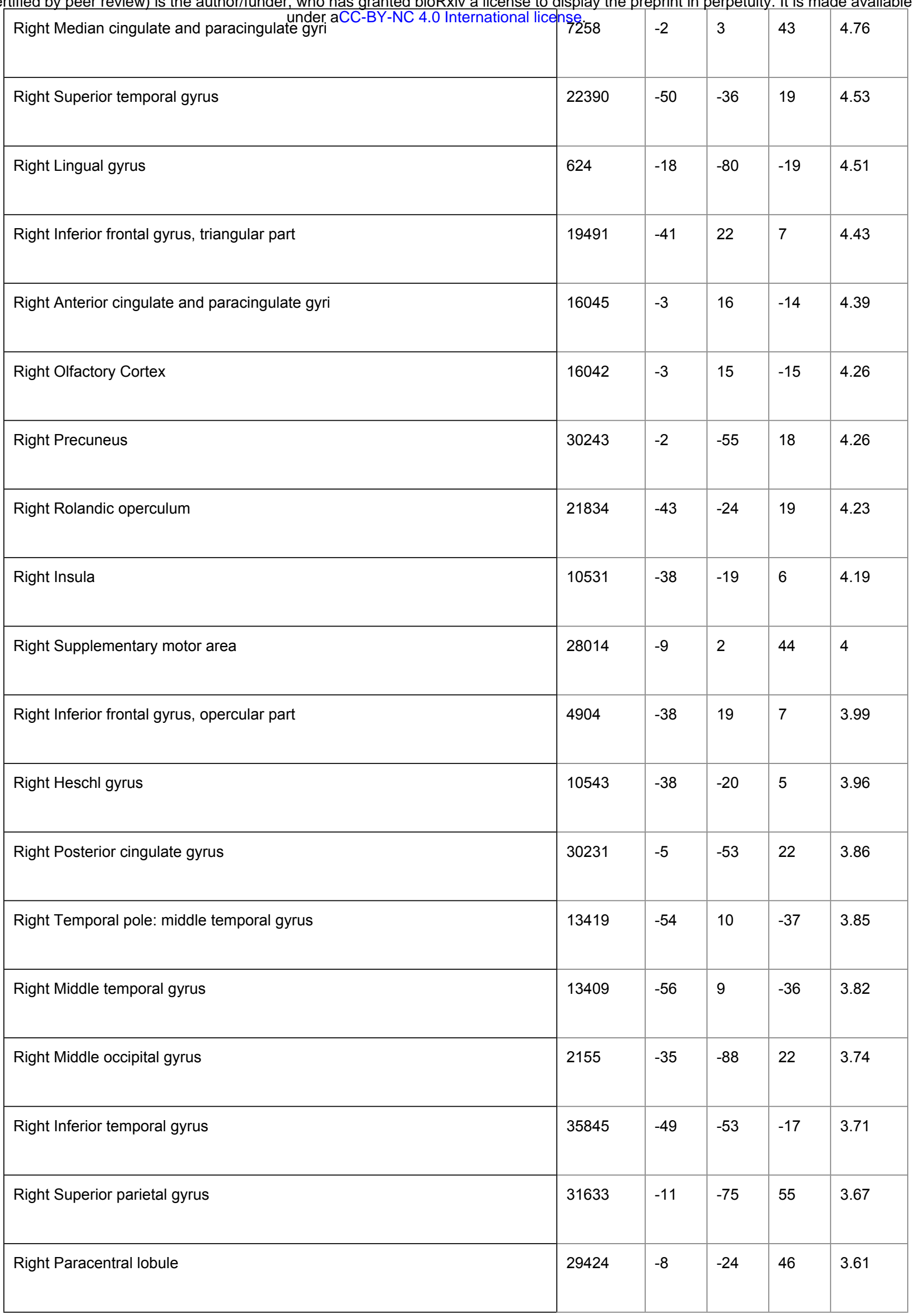


bioRxiv preprint doi: https://doi.org/10.1101/306068; this version posted September 7, 2018. The copyright holder for this preprint (which was not certified by peer review) is the author/funder, who has granted bioRxiv a license to display the preprint in perpetuity. It is made available

\begin{tabular}{|c|c|c|c|c|c|}
\hline Right Temporal pole: superior temporal gyrus & nșe. & -44 & 10 & -17 & 3.58 \\
\hline Right Cuneus & 31915 & -17 & -67 & 20 & 3.51 \\
\hline Right Postcentral gyrus & 22201 & -48 & -23 & 19 & 3.51 \\
\hline Right Superior frontal gyrus, medial & 4440 & -4 & 52 & 25 & 3.49 \\
\hline Right Fusiform gyrus & 36625 & -42 & -22 & -21 & 3.48 \\
\hline Right Calcarine fissure and surrounding cortex & 39428 & -16 & -89 & -19 & 3.45 \\
\hline Right Middle frontal gyrus & 20452 & -46 & 23 & 29 & 3.4 \\
\hline Right Inferior frontal gyrus, orbital part & 19161 & -52 & 37 & -5 & 3.37 \\
\hline Right Superior occipital gyrus & 31667 & -17 & -80 & 40 & 3.23 \\
\hline Right Superior frontal gyrus, dorsolateral & 18009 & -25 & 52 & 34 & 3.13 \\
\hline Right Superior frontal gyrus, medial orbital & 15996 & -1 & 18 & -17 & 3.11 \\
\hline Right Inferior occipital gyrus & 35407 & -48 & -63 & -10 & 3.03 \\
\hline Right Inferior parietal, but supramarginal and angular gyri & 23511 & -45 & -45 & 46 & 3.02 \\
\hline Right Supeiror frontal gyrus, orbital part & 13938 & -25 & 31 & -18 & 2.86 \\
\hline Right Parahippocampal gyrus & 14247 & -24 & 2 & -26 & 2.83 \\
\hline Right Angular gyrus & 24035 & -27 & -66 & 34 & 2.82 \\
\hline Right Precentral gyrus & 21025 & -39 & -18 & 43 & 2.75 \\
\hline Right Middle frontal gyrus orbital part & 18981 & -33 & 58 & 3 & 2.63 \\
\hline
\end{tabular}

Supplementary Table 14. Right precommisural putamen volume significant peaks of correlation with cortical thickness for HC. 
bioRxiv preprint doi: https://doi.org/10.1101/306068; this version posted September 7, 2018. The copyright holder for this preprint (which was not certified by peer review) is the author/funder, who has granted bioRxiv a license to display the preprint in perpetuity. It is made available under aCC-BY-NC 4.0 International license.

\begin{tabular}{|c|c|c|c|c|c|}
\hline Brain Areas & vertex & $\mathbf{x}$ & $\mathbf{y}$ & $\mathbf{z}$ & $\mathbf{t}$ \\
\hline Left Calcarine fissure and surrounding cortex & 33299 & -13 & -92 & -18 & 5.84 \\
\hline Left Median cingulate and paracingulate gyri & 29831 & -8 & -21 & 43 & 5.21 \\
\hline Left Lingual gyrus & 39421 & -14 & -88 & -20 & 5.1 \\
\hline Left Middle frontal gyrus & 19041 & -40 & 53 & 8 & 4.61 \\
\hline Left Middle occipital gyrus & 34574 & -44 & -69 & 18 & 4.41 \\
\hline Left Superior frontal gyrus, medial orbital & 4262 & -4 & 58 & -14 & 4.33 \\
\hline Left Inferior frontal gyrus, triangular part & 19188 & -45 & 34 & 16 & 4.28 \\
\hline Left Precuneus & 31342 & -4 & -67 & 44 & 4.21 \\
\hline Left Gyrus Rectus & 16932 & -3 & 58 & -15 & 4.02 \\
\hline Left Inferior occipital gyrus & 576 & -59 & -60 & -9 & 3.92 \\
\hline Left Insula & 2639 & -40 & -16 & 4 & 3.88 \\
\hline Left Superior frontal gyrus, medial & 27542 & -7 & 55 & 42 & 3.82 \\
\hline Left Posterior cingulate gyrus & 30166 & -3 & -37 & 37 & 3.81 \\
\hline Left Inferior temporal gyrus & 35940 & -59 & -59 & -9 & 3.81 \\
\hline Left Superior occipital gyrus & 8131 & -28 & -85 & 31 & 3.78 \\
\hline Left Middle temporal gyrus & 35910 & -61 & -54 & -7 & 3.75 \\
\hline Left Superior frontal gyrus, dorsolateral & 26560 & -21 & 19 & 61 & 3.61 \\
\hline
\end{tabular}


bioRxiv preprint doi: https://doi.org/10.1101/306068; this version posted September 7, 2018. The copyright holder for this preprint (which was not certified by peer review) is the author/funder, who has granted bioRxiv a license to display the preprint in perpetuity. It is made available

\begin{tabular}{|c|c|c|c|c|c|}
\hline Left Heschl gyrus $\quad$ under & 2642 & -39 & -19 & 4 & 3.53 \\
\hline Left Inferior frontal gyrus, opercular part & 20149 & -50 & 13 & 22 & 3.46 \\
\hline Left Middle frontal gyrus orbital part & 19079 & -42 & 52 & 1 & 3.32 \\
\hline Left Superior temporal gyrus & 10435 & -41 & -18 & -1 & 3.28 \\
\hline Left Supplementary motor area & 28231 & -3 & 24 & 37 & 3.21 \\
\hline Left Fusiform gyrus & 153 & -34 & -51 & -20 & 3.15 \\
\hline Left Cuneus & 32804 & -2 & -89 & 28 & 3.08 \\
\hline Left Rolandic operculum & 10626 & -35 & -27 & 18 & 3.01 \\
\hline Left Angular gyrus & 23401 & -49 & -68 & 33 & 3.01 \\
\hline Left Supramarginal gyrus & 21863 & -37 & -29 & 19 & 2.98 \\
\hline Left Precentral gyrus & 26769 & -24 & -3 & 54 & 2.88 \\
\hline Left Anterior cingulate and paracingulate gyri & 16778 & -9 & 43 & 15 & 2.88 \\
\hline Left Supeiror frontal gyrus, orbital part & 17100 & -14 & 63 & -11 & 2.79 \\
\hline Left Postcentral gyrus & 22201 & -48 & -23 & 19 & 2.78 \\
\hline Right Median cingulate and paracingulate gyri & 28922 & -1 & 1 & 43 & 5.39 \\
\hline Right Inferior frontal gyrus, triangular part & 19223 & -52 & 33 & 11 & 4.45 \\
\hline Right Precuneus & 30243 & -2 & -55 & 18 & 4.4 \\
\hline Right Posterior cingulate gyrus & 30225 & -4 & -53 & 22 & 4.2 \\
\hline Right Superior frontal gyrus, medial orbital & 4394 & -3 & 68 & -8 & 4.04 \\
\hline
\end{tabular}


bioRxiv preprint doi: https://doi.org/10.1101/306068; this version posted September 7, 2018. The copyright holder for this preprint (which was not certified by peer review) is the author/funder, who has granted bioRxiv a license to display the preprint in perpetuity. It is made available

\begin{tabular}{|c|c|c|c|c|c|}
\hline Right Insula under a & 1se. & -36 & 23 & -2 & 4.04 \\
\hline Right Middle frontal gyrus & 20386 & -41 & 16 & 35 & 3.99 \\
\hline Right Supplementary motor area & 28008 & -8 & 5 & 42 & 3.98 \\
\hline Right Middle occipital gyrus & 34407 & -43 & -83 & 13 & 3.93 \\
\hline Right Superior frontal gyrus, medial & 4415 & -4 & 69 & -5 & 3.88 \\
\hline Right Supramarginal gyrus & 22221 & -49 & -32 & 18 & 3.86 \\
\hline Right Inferior temporal gyrus & 35811 & -59 & -52 & -24 & 3.81 \\
\hline Right Anterior cingulate and paracingulate gyri & 16045 & -3 & 16 & -14 & 3.75 \\
\hline Right Olfactory Cortex & 16042 & -3 & 15 & -15 & 3.74 \\
\hline Right Middle temporal gyrus & 34636 & -50 & -62 & 10 & 3.72 \\
\hline Right Heschl gyrus & 10543 & -38 & -20 & 5 & 3.68 \\
\hline Right Rolandic operculum & 21836 & -40 & -25 & 19 & 3.65 \\
\hline Right Superior temporal gyrus & 10906 & -57 & -3 & -13 & 3.58 \\
\hline Right Supeiror frontal gyrus, orbital part & 17593 & -15 & 70 & -8 & 3.53 \\
\hline Right Cuneus & 31552 & -16 & -80 & 38 & 3.49 \\
\hline Right Superior frontal gyrus, dorsolateral & 17582 & -14 & 71 & -2 & 3.24 \\
\hline Right Angular gyrus & 5611 & -62 & -51 & 33 & 3.17 \\
\hline Right Paracentral lobule & 7387 & -7 & -24 & 47 & 3.17 \\
\hline Right Fusiform gyrus & 36625 & -42 & -22 & -21 & 3.14 \\
\hline
\end{tabular}


bioRxiv preprint doi: https://doi.org/10.1101/306068; this version posted September 7, 2018. The copyright holder for this preprint (which was not certified by peer review) is the author/funder, who has granted bioRxiv a license to display the preprint in perpetuity. It is made available

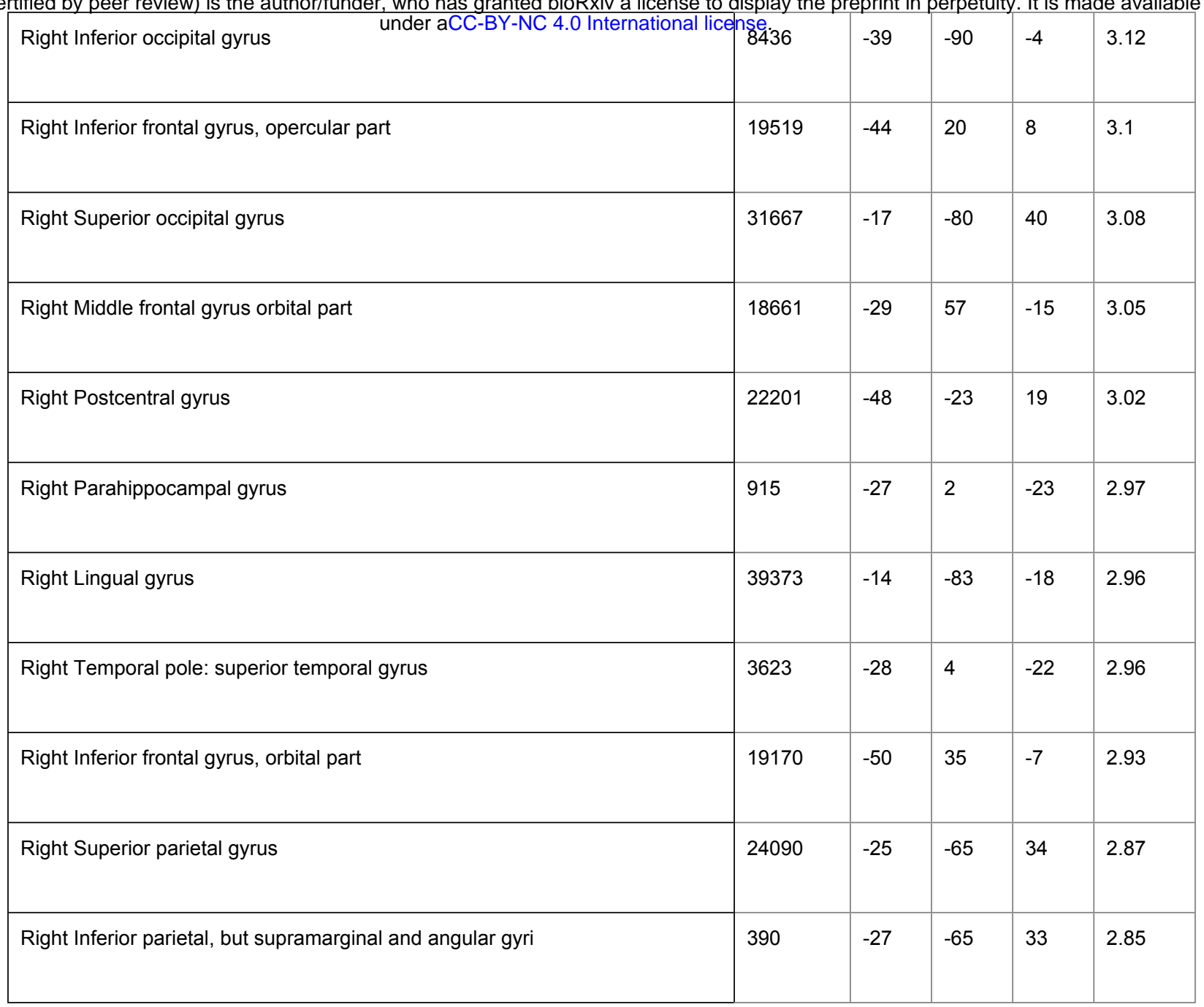

Supplementary Table 15. Right precommisural putamen volume significant peaks of correlation with cortical thickness for AD.

\begin{tabular}{|l|l|l|l|l|l|}
\hline Brain Areas & vertex & $\mathbf{x}$ & $\mathbf{y}$ & $\mathbf{z}$ & $\mathbf{t}$ \\
\hline Left Superior temporal gyrus & 13033 & -44 & 3 & -15 & 4.86 \\
\hline Left Temporal pole: superior temporal gyrus & 3278 & -44 & 6 & -15 & 4.53 \\
\hline Left Temporal pole: middle temporal gyrus & 13285 & -48 & 13 & -30 & 4.4 \\
\hline Left Middle temporal gyrus & & & & & \\
\hline Left Inferior occipital gyrus & 13282 & -49 & 13 & -29 & 4.36 \\
\hline
\end{tabular}


bioRxiv preprint doi: https://doi.org/10.1101/306068; this version posted September 7, 2018. The copyright holder for this preprint (which was not certified by peer review) is the author/funder, who has granted bioRxiv a license to display the preprint in perpetuity. It is made available

\begin{tabular}{|l|l|l|l|l|l|}
\hline Left Precentral gyrus & & & & \\
\hline
\end{tabular}

